\title{
Indonesia: 2008 Article IV Consultation-Staff Report; Staff Statement; Public Information Notice on the Executive Board Discussion; and Statement by the Executive Director for Indonesia
}

Under Article IV of the IMF's Articles of Agreement, the IMF holds bilateral discussions with members, usually every year. In the context of the 2008 Article IV consultation with Indonesia, the following documents have been released and are included in this package:

- $\quad$ The staff report for the 2008 Article IV consultation, prepared by a staff team of the IMF, following discussions that ended on May 28, 2008, with the officials of Indonesia on economic developments and policies. Based on information available at the time of these discussions, the staff report was completed on July 11, 2008. The views expressed in the staff report are those of the staff team and do not necessarily reflect the views of the Executive Board of the IMF.

- A staff statement of August 1, 2008, updating information on recent developments.

- $\quad$ A Public Information Notice (PIN) summarizing the views of the Executive Board as expressed during its Board meeting on August 1, 2008, discussion of the staff report that concluded the Article IV consultation.

- $\quad$ A statement by the Executive Director for Indonesia.

The documents listed below will be separately released.

\section{Selected Issues Paper}

The policy of publication of staff reports and other documents allows for the deletion of market-sensitive information.

\footnotetext{
Copies of this report are available to the public from

International Monetary Fund • Publication Services

$70019^{\text {th }}$ Street, N.W. $\bullet$ Washington, D.C. 20431

Telephone: (202) 623-7430 • Telefax: (202) 623-7201

E-mail: publications@imf.org •Internet: http://www.imf.org
}

Price: $\$ 18.00$ a copy

\section{International Monetary Fund Washington, D.C.}



INTERNATIONAL MONETARY FUND

INDONESIA

\section{Staff Report for the 2008 Article IV Consultation}

Prepared by the Staff Representatives for the 2008 Consultation with Indonesia

Approved by Daniel Citrin and Tessa van der Willigen

July 11,2008

- This report is based on discussions held in Jakarta during May 15-28, 2007. The staff team comprised Messrs. Zavadjil (head), Reichold (all APD), Le Borgne (FAD), and Mesdames Ruiz Arranz (APD) and McCaughrin (MCM). Messrs. Schwartz, Senior Resident Representative, and Morales, Deputy Resident Representative, participated in the mission. Messrs. Warjiyo and Agung from the Executive Director's Office also attended meetings.

- Counterparts: Discussions were held with the previous Coordinating Minister for Economic Affairs and newly appointed Bank Indonesia Governor Boediono, Minister of Finance and now also Coordinating Minister for Economic Affairs Sri Mulyani Indrawati, Coordinating Minister for Social Affairs Aburizal Bakrie, Minister of Trade Mari Pangestu, Minister of Planning Paskah Suzetta, Minister of Energy and Natural Resources Purnomo Yusgiantoro, and other senior officials, as well as representatives of the private sector and academia.

- Context of past surveillance: Close relations between the authorities and the Fund are being maintained. The staff has been supportive of the authorities' policy priorities and policy implementation has been broadly consistent with recent Fund policy recommendations in most areas (Table 1).

- Indonesia's exchange rate regime is a managed float. Indonesia has accepted the obligations under Article VIII, Sections 2, 3, and 4, and maintains an exchange system free of restrictions on the making of payments and transfers for current international transactions.

- Statistics are broadly adequate for surveillance purposes, although they could be improved in some areas (Annex IV). Indonesia subscribes to the Special Data Dissemination Standard. The statistics ROSC was completed in early 2005. A fiscal ROSC update was conducted during this Article IV mission. 


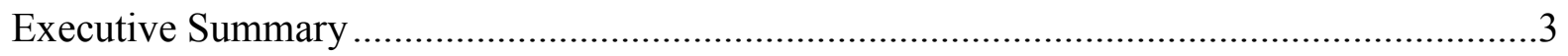

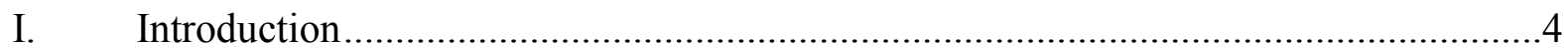

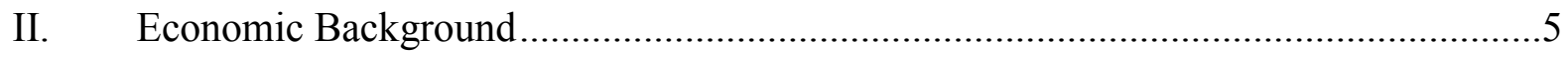

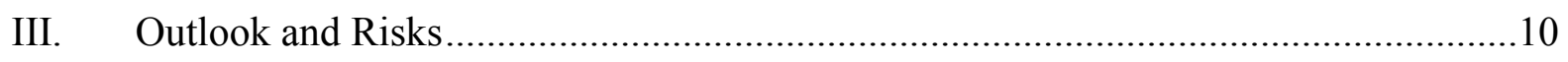

IV. Discussions of Key Policy Challenges ...............................................................11

A. Monetary and Exchange Rate Policies: Responding to Rising Inflation ................11

B. Fiscal Policy: Implications and Sustainability of Fuel Subsidies ........................17

C. Financial Sector Policies: Implications of the Global Financial Market Turmoil ..19

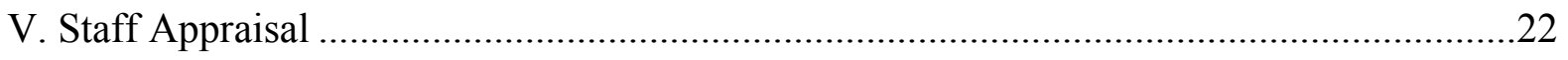

\section{Boxes}

1. Financial Market Spillovers: Evidence from Recent Data .....................................12

2. Exchange Rate Assessment.................................................................................. 16

3. The Impact of the Oil Prices on the Budget........................................................ 18

4. Stress Test Analysis on Indonesia's Banking System ............................................21

Figures

1. Recent Macroeconomic Performance and Outlook ..................................................6

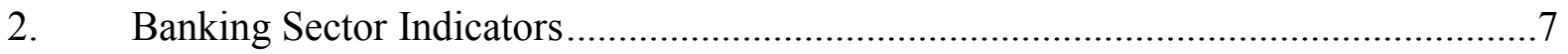

3. Financial Market Performance........................................................................

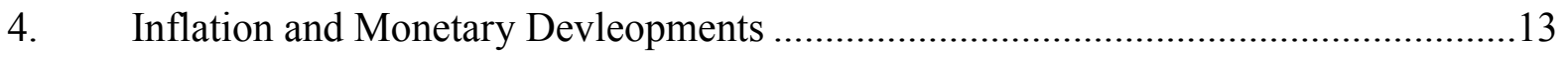

Tables

1. The Authorities' Response to Recent Fund Policy Advice ......................................25

2. Selected Economic and Financial Indicators, 2005-09 ...........................................26

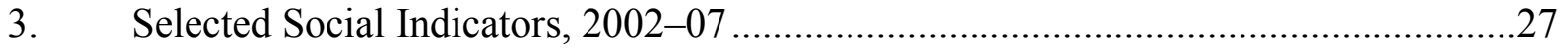

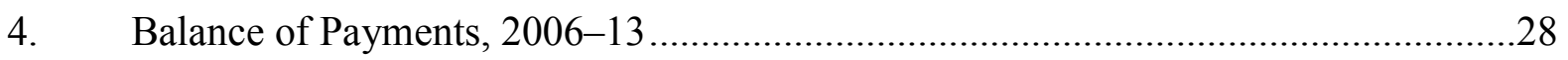

5. Monetary Survey, December 2005 to December 2008 .........................................29

6. Summary of Central Government Operations, 2005-08 ............................................30

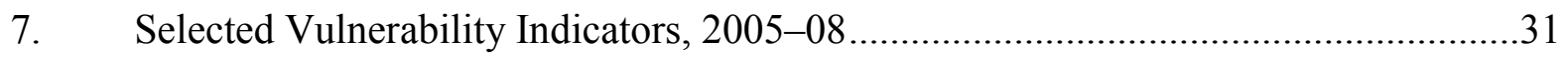

8. Medium-Term Macroeconomic Framework, 2007-13 ...........................................32

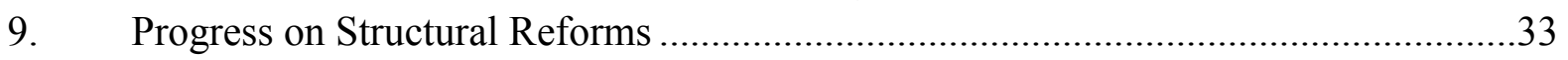

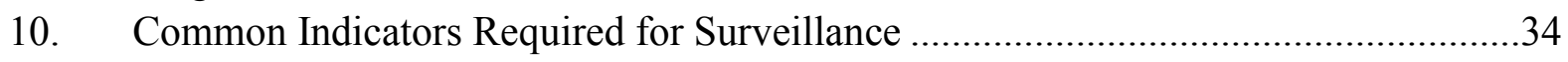

Appendix

I. Medium-Term Outlook Under an Adverse Macro Scenario and Public and External Debt Sustainability 


\section{Executive Summary}

\section{Background and outlook}

- Indonesia's growth performance remains strong despite the deteriorating global environment. Growth is expected to remain at over 6 percent in 2008 on favorable resource sector activity and increased investment.

- While inflation remained within the target range at end-2007, it has accelerated since and is expected to reach 12 percent at the end of the year, reflecting large increases in food and fuel prices, as well as demand pressures. In response, Bank Indonesia (BI) has started to tighten monetary policy (by 75 basis points since May).

- The government raised subsidized fuel prices by 29 percent in May, the first time since 2005. Nevertheless, energy subsidies remain sizeable (5 percent of GDP in 2008).

- Indonesia's financial sector has displayed resilience in the face of the global credit market turmoil and financial soundness indicators continue to improve. However, the economy remains vulnerable to shifts in investor sentiment and volatility in the government bond market has increased.

\section{Policy Discussions}

- Staff and the authorities agree that monetary tightening, supported by some exchange rate appreciation, is warranted to put inflation back on a downward path. Staff recommended that interest rates will need to be brought promptly to a more neutral 2-3 percent in real terms to limit the second-round effects of the fuel price increase. The authorities believe that this can be achieved by somewhat smaller rate increases. As the 2008 inflation target will be missed, effective communication and a credible commitment to the medium-term inflation objectives will be important to anchor inflationary expectations.

- The new policy of increased reselling of official foreign exchange receipts from oil exports should support the rupiah and help dampen inflation, but a more automatic mechanism for recycling official reserves would, in addition, enhance liquidity and foreign exchange market development. The rupiah is seen as moderately undervalued.

- The fiscal stance is consistent with a continued reduction in the public debt burden, but high energy subsidies could further reduce the scope for spending on priority areas. While staff suggested introducing automatic adjustments of fuel prices (or, as second best, ad-hoc adjustments) to improve the composition of spending, the authorities noted that further price increases may not be feasible ahead of the 2009 elections and are, instead, considering options to limit the consumption of subsidized fuel.

- Financial sector policies should focus on maintaining the stability and the soundness of the financial system. Private sector credit growth and standards for new loan approval should be closely monitored and prudential regulations should not be loosened further. 


\section{INTRODUCTION}

1. Since the conclusion of the last Article IV consultation in mid-2007, Indonesia's growth performance has remained strong despite the deteriorating global environment. In 2007, the economy recorded the highest growth rate in a decade (over 6 percent) and the momentum was maintained in Q1 2008. As a result, poverty and unemployment have declined significantly, though they remain high at 15.4 percent and 8.5 percent, respectively.

\section{Nevertheless, new challenges have emanated from rising commodity prices.} Government bond yields have spiked since end-February as investor sentiment deteriorated due to surging fuel subsidies and inflation concerns. Domestic fuel prices were subsequently increased by about 29 percent and Bank Indonesia (BI) started raising interest rates in May, but uncertainty remains as international oil and food prices have continued to rise and global growth is expected to slow in 2008. Meanwhile, external financing conditions have tightened somewhat as a result of the global financial market turmoil. All this said, overall, Indonesia remains in good shape to weather these challenges and has positive prospects, assuming flexible macroeconomic policy responses to deal with fuel subsidies and inflation.

3. While having to handle these short-term issues, the authorities are also focusing on accelerating growth and improving social conditions. As discussed extensively in previous Article IV reports, investment remains low by regional standards, in large part reflecting the relatively weak investment climate and governance issues. The lack of infrastructure is also seen as a major constraint to growth. In attempting to address these issues, progress was made last year, with the passage of the investment law and a key tax law, as well as a series of measures to improve the business climate. However, other elements of the reform agenda (e.g., the VAT and the income tax laws) have not yet been passed by parliament, though the authorities are hopeful of early approval. Labor market reform has been slowed by political resistance, and any progress will likely occur only after the 2009 general elections (Table 9).

4. Against this background, the discussions focused on the: (i) inflation outlook and appropriate monetary and exchange rate policies; (ii) impact of the fuel price adjustment and options to contain fuel subsidies in the context of volatile global oil prices; and (iii) fallout of the global financial turmoil and economic slowdown on the financial system, and regulatory implications. Progress in structural reforms was discussed extensively in previous Article IV consultations and key areas have recently been covered by other multilateral institutions. ${ }^{1}$

\footnotetext{
${ }^{1}$ See, for example, the OECD Economic Review of Indonesia (June 9, 2008).
} 


\section{ECONOMIC BACKGROUND}

\section{Strong growth has been accompanied by increasing inflation.}

- Growth of 6.3 percent in 2007 was driven by domestic demand, both robust private consumption and a rebound in investment that included a strong rise in foreign direct investment. While exports performed strongly, supported by continuing demand for Indonesia's commodities, the recovery of imports in the second half of the year reduced the contribution of net exports to growth. The growth momentum was maintained in the first quarter of 2008 despite the deterioration in consumer confidence (Figure 1). ${ }^{2}$

- Headline inflation has accelerated to 11.0 percent at end-June, while core inflation reached 8.7 percent at end-May (latest available data). ${ }^{3}$ Part of this uptick owes to the impact of the fuel price adjustment in late May. However, fueled by high food prices and demand pressures, headline inflation had already reached 9 percent at end-April, well above BI's 4-6 percent target range for end-2008.

\section{Accommodative monetary policy appears to have contributed to the rise in} inflationary pressures since mid-2007. After lowering interest rates to 8 percent and then holding them unchanged since late 2007, BI hiked rates three times since May by atotal of 75 basis points in response to rising inflation. Furthermore, bank liquidity has been tightened in 2008, as the overnight rate has increased by about 400 basis points from the average level in December 2007 in line with the implementation of the change in the monetary operations framework (see paragraph 20). Nevertheless, the real policy interest rate calculated on the basis of core inflation has been declining over the year and is currently around zero.

\section{The relative weakness of the rupiah may have also added to inflationary} pressures in the second half of $\mathbf{2 0 0 7}$, but the external position remains generally strong. The real exchange rate remains moderately undervalued, as discussed in paragraph 18. Nevertheless, the nominal effective exchange rate (NEER) depreciated further (by 10 percent) in 2007 as Indonesia accumulated US $\$ 14$ billion of reserves. However, in 2008 the NEER has remained stable and BI has slowed the accumulation of reserves. While the current account recorded a surplus of 2.5 percent of GDP in 2007 supported by gains in the price of major commodity exports, there have been some episodes of capital outflows.

\footnotetext{
${ }^{2}$ Worsening consumer confidence is largely attributed to rising inflation. Nevertheless, the historical correlation between this indicator and consumption growth and activity has been low.

${ }^{3}$ Starting with the June data, the statistics bureau rebased the CPI index to reflect changes in buying patterns, resulting in a reduced the weight of food and higher weights of communications and transportation. This rebasing is conducted every five years. While historical data are yet to be revised to make comparisons possible, it is estimated that inflation through May may have been about $1 \frac{1}{2}$ percentage points lower using the weights in the new base year.
} 
Figure 1. Indonesia: Recent Macroeconomic Performance and Outlook

Despite the drop in consumer confidence,

consumption...

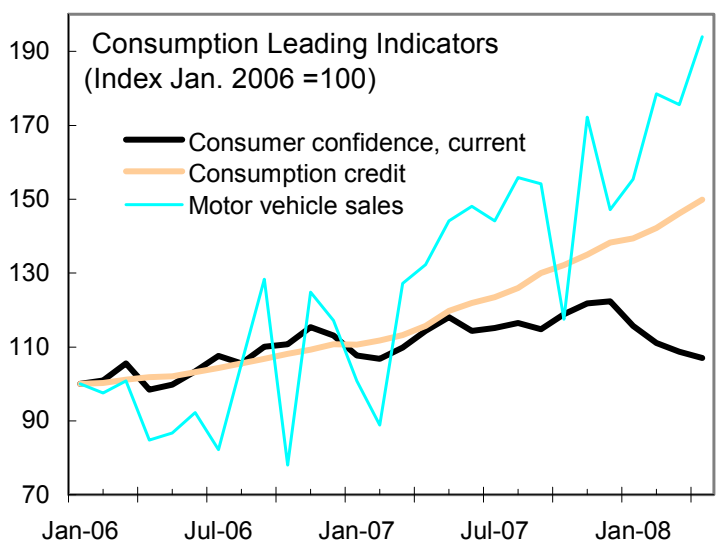

...supported by accelerating credit growth.

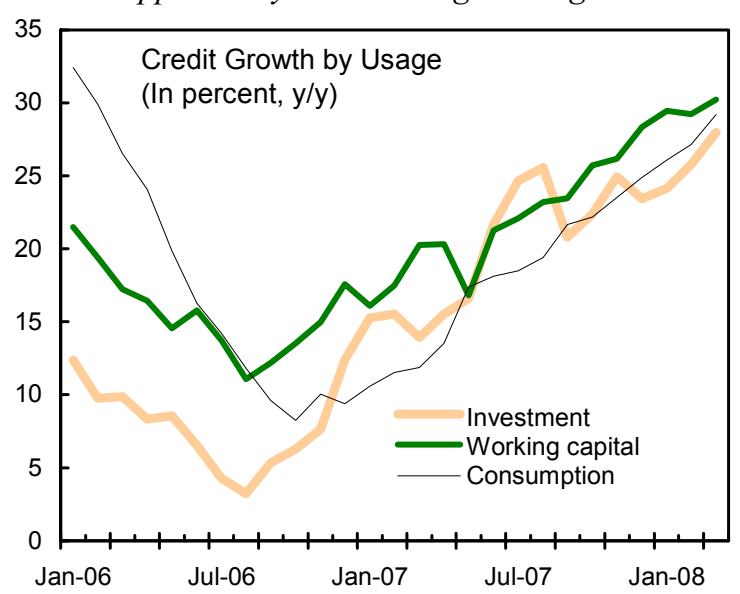

...driven increasingly by domestic demand...

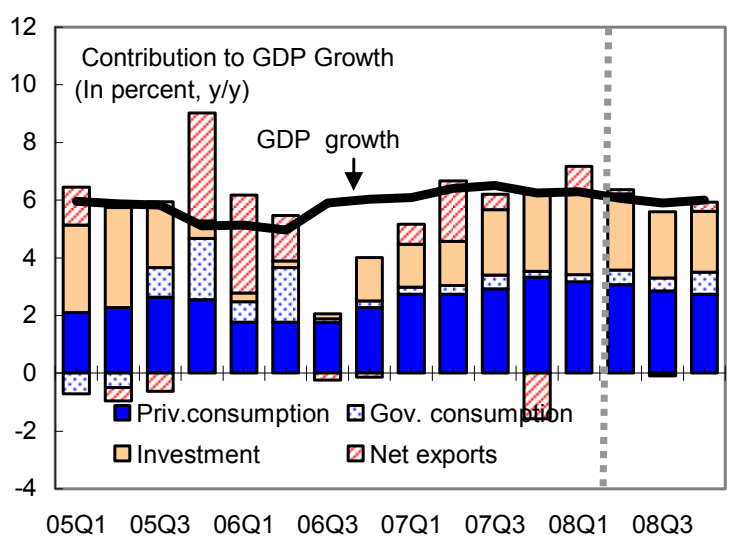

... and investment indicators remain

generally strong,

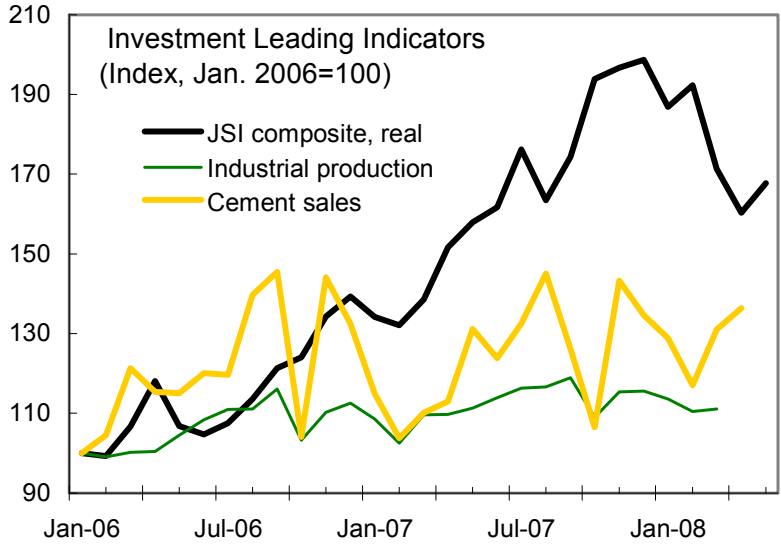

GDP growth is expected to maintain momentum...

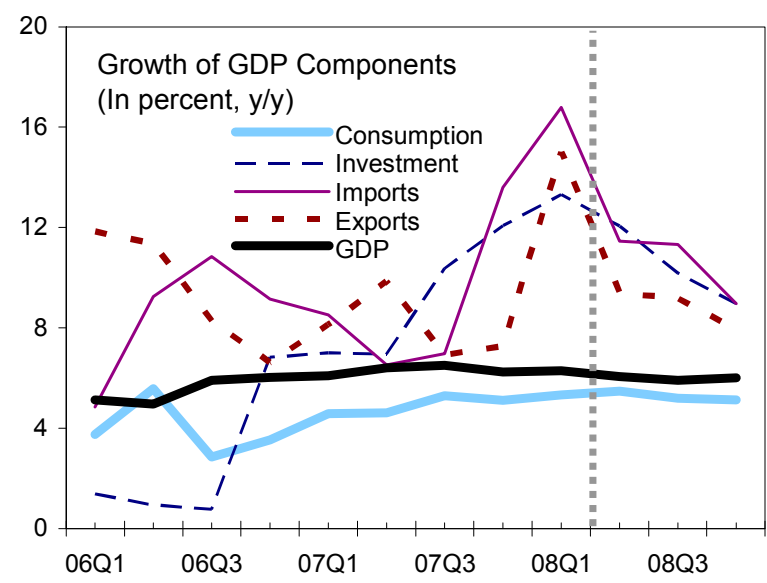

...while imports are growing strongly to support investment.

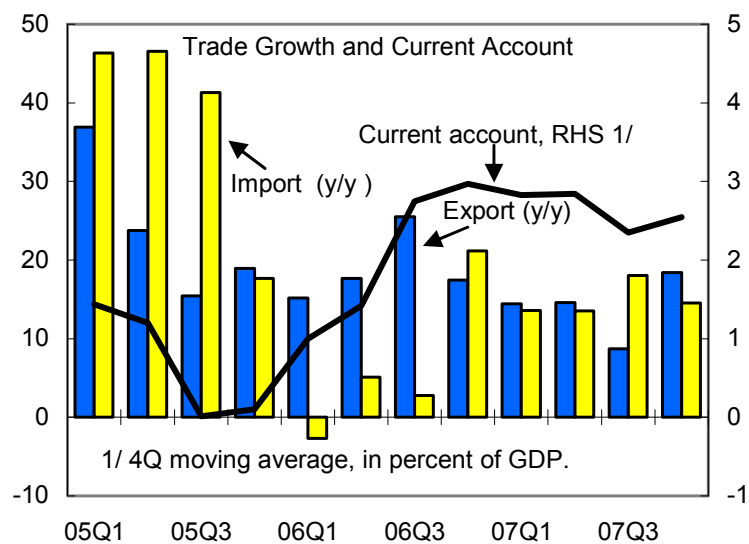

Sources: CEIC Data Co, Ltd.; and Fund staff estimates. 
Figure 2. Indonesia: Banking Sector Indicators
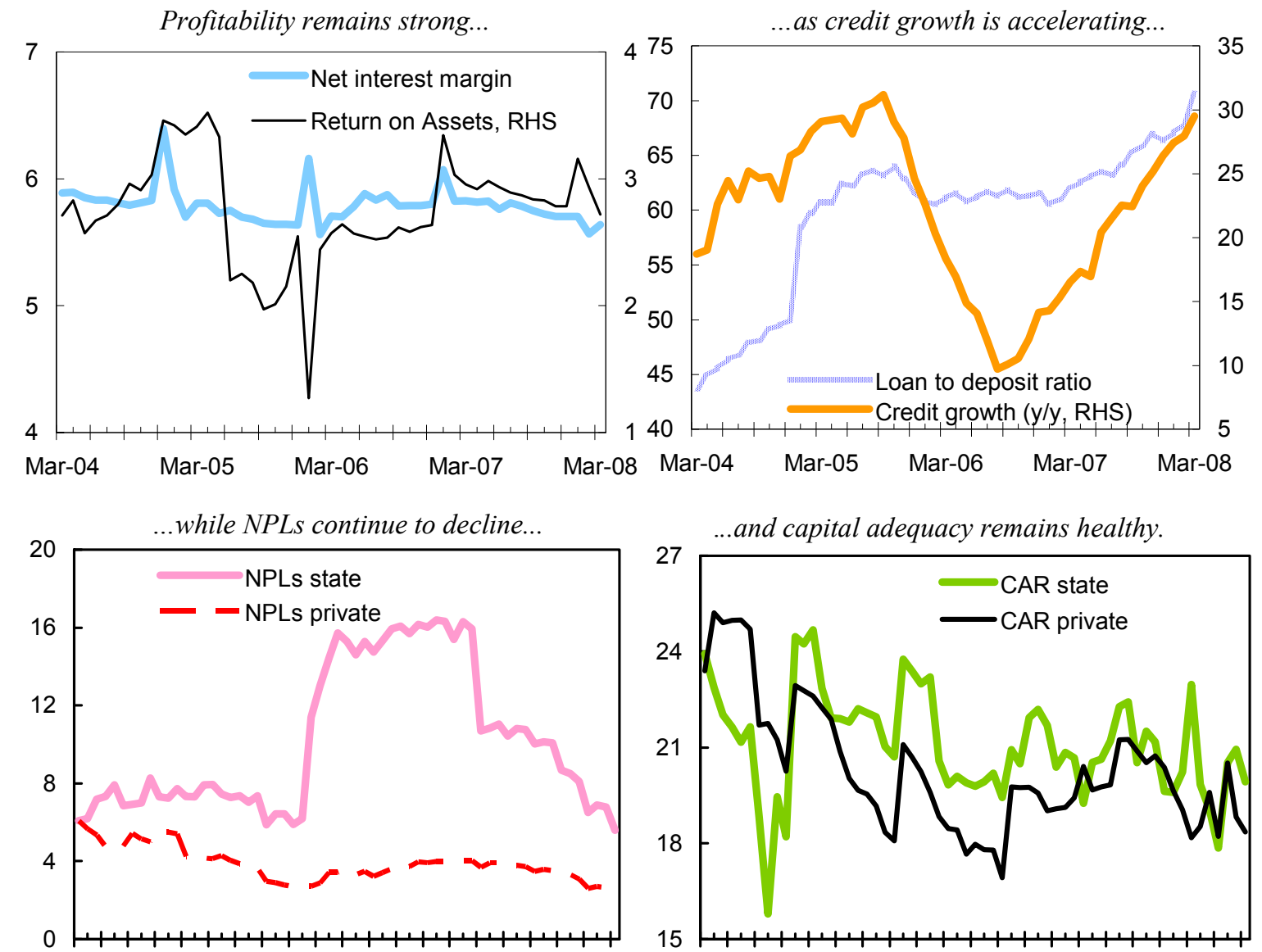

Mar-03 Mar-04 Mar-05 Mar-06 Mar-07 Mar-08 Mar-03 Mar-04 Mar-05 Mar-06 Mar-07 Mar-08

However, contingent Claims analysis ....some increase in the risk of default since the
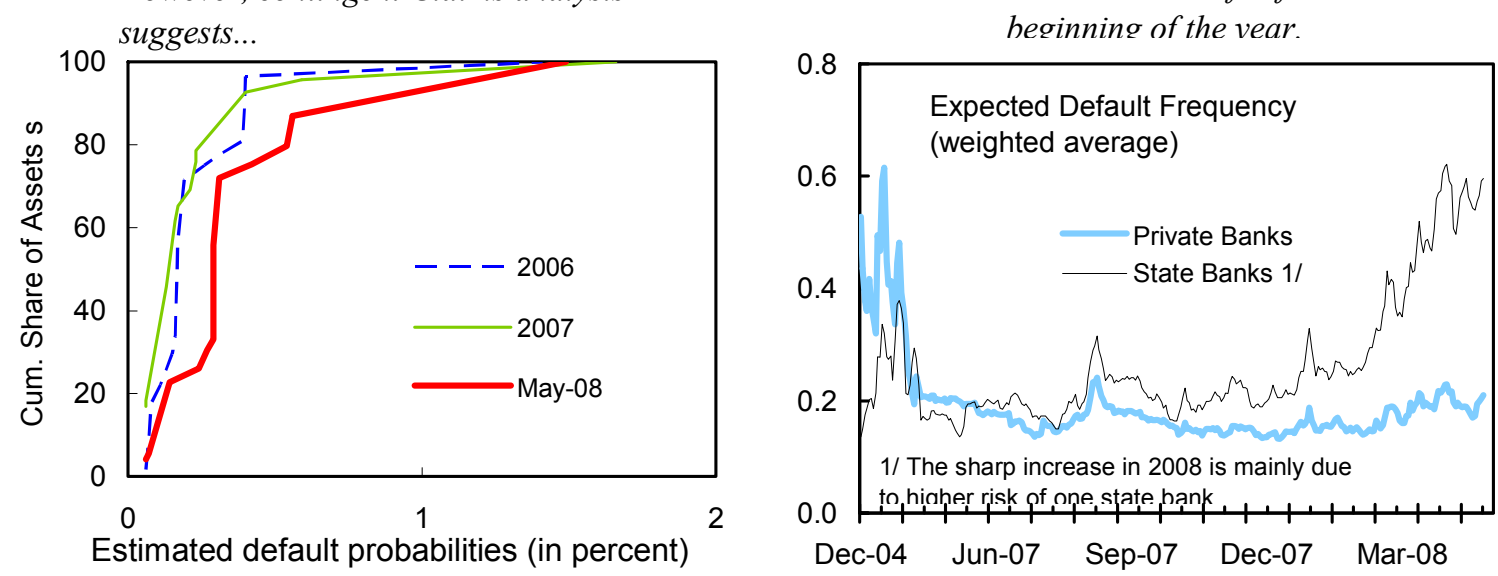

Sources: Indonesian authorities; CEIC Data Co, Ltd.; and Fund staff calculations. 
8. Fiscal performance has been strong despite rising fuel subsidies. Energy subsidies rose to 3 percent of GDP in 2007 (almost a third of total current spending). Nevertheless, the fiscal deficit was contained to 1.2 percent of GDP, well below the government's target. Revenue performance was buoyant, with an across the board surge in non-oil and gas revenue being a testament to both the underlying strength of the economy and payoff from ongoing reforms in tax administration. Budget execution has also improved noticeably, in particular in the area of development expenditure.

\section{Indonesia's financial sector has displayed resilience in the face of the global} credit market turmoil. Financial soundness indicators have improved, with banking sector profitability increasing, and gross NPLs declining to 4 percent amid strong private credit growth (Figure 2). The stock market index remains about 6 percent above the level at endJune 2007. Nevertheless, volatility has increased, and since end-February, EMBI and CDS spreads have widened more than in other emerging market countries. Several factors have limited the transmission of global financial shocks:

\section{- Reduced external vulnerabilities.} International reserves currently exceed 150 percent of short-term external debt, and both external and domestic debt ratios are on a declining trend.

- Low exposure to structured credit and derivative products. Bank lending and

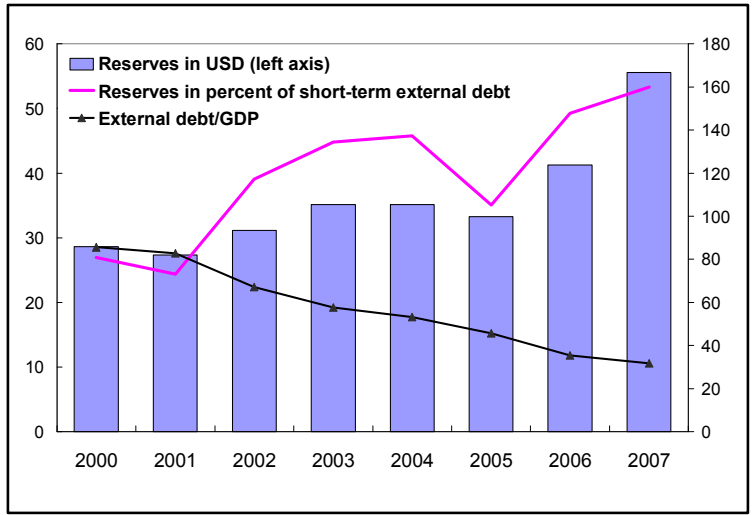
local bond market investments have been profitable, which limited the need to look for higher yields in alternative investments. Lending to the private sector is growing by almost 30 percent in line with economic activity and low real interest rates.

- Ample domestic liquidity. The banking sector is well capitalized and highly liquid.

- Relatively low reliance on external financing. Both strong profitability and ample domestic credit, have allowed Indonesian corporations to continue to finance their investments despite the higher cost of external funds. Moreover, vulnerabilities have declined as debt to asset ratios have fallen. ${ }^{4}$

\section{Nevertheless, the government bond market came under stress in March,} reflecting largely investors' concerns about inflation and fuel subsidies (Figure 3). Bond yields have spiked by about 300 basis points since end-February. Some bond auctions have not attracted the targeted demand, although the government was successful in raising $\$ 2.2$ billion in an external bond issue in June.

\footnotetext{
${ }^{4}$ See Selected Issues paper: Corporate Financing in Indonesia: Challenges amid changing financial conditions.
} 
Figure 3. Indonesia: Financial Market Performance

Government bond yields rose following inflation news in early March ...

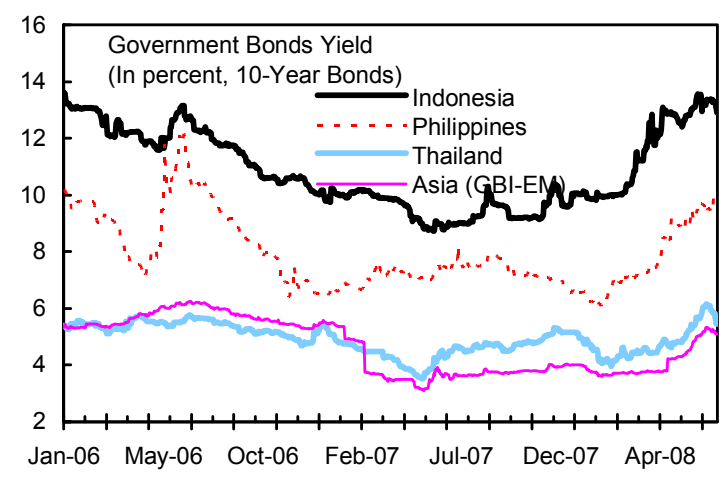

Indonesian global bonds underperformed relative to their emerging market peers...
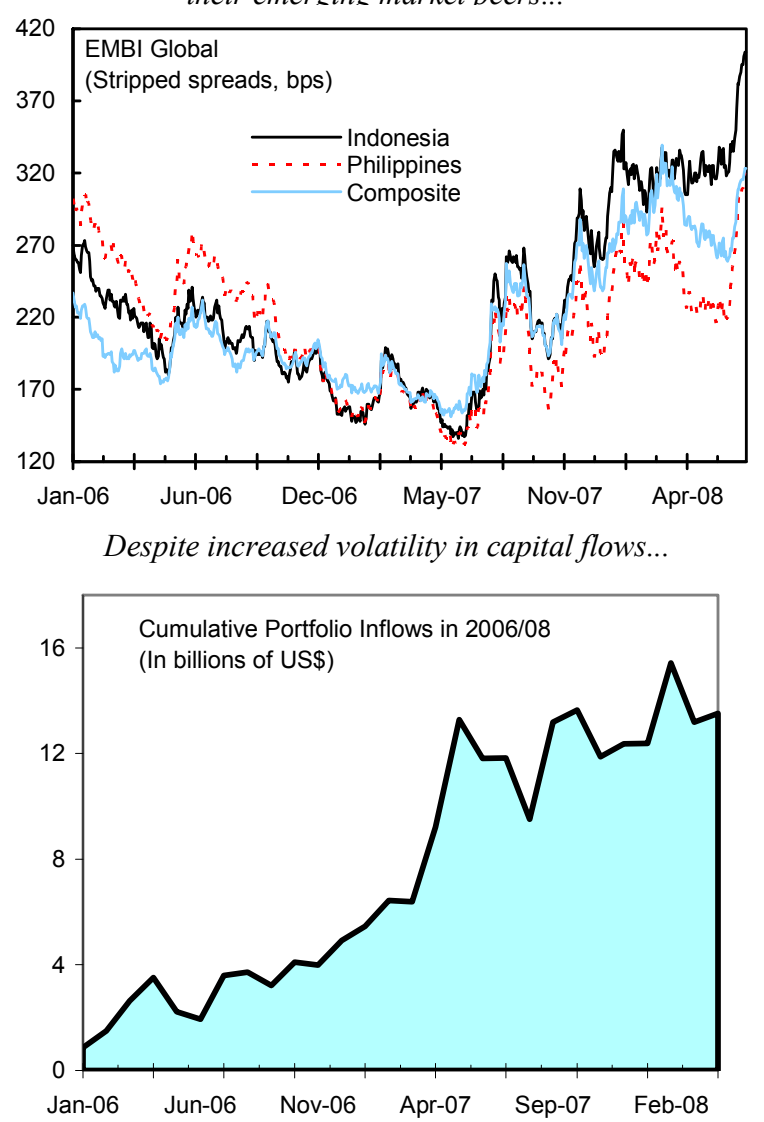

... and have again reached the level of end-2005.

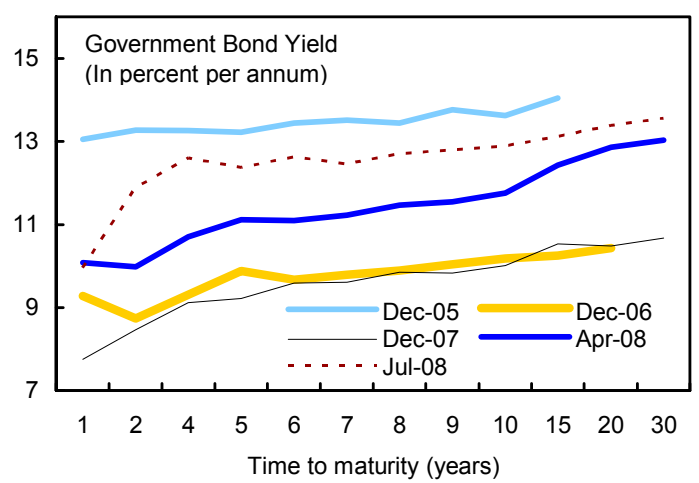

... and some of the gains in the equity market during 2007 have been eroded.

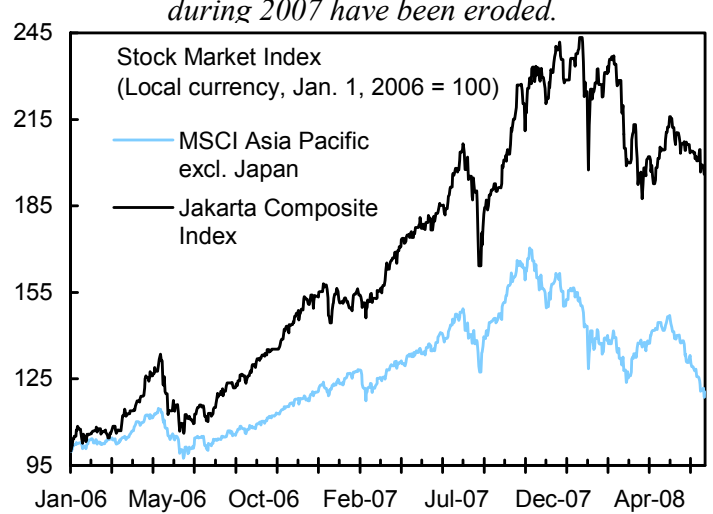

...the exchange rate has remained stable against the

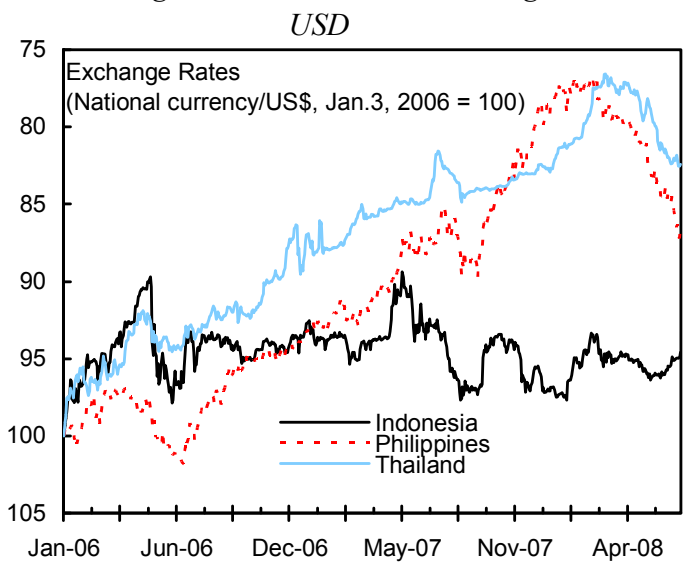

Sources: CEIC database; Bloomberg; country authorities; and Fund staff calculations.. 


\section{OUTLOOK AND RISKS}

11. Notwithstanding the weakening external environment, Indonesia's growth is expected to remain strong, assuming timely responses to changing economic conditions.

- Growth is projected by the staff to slow slightly to 6.1 percent in 2008 . After a stronger-than-expected first quarter, some weakening is expected in the second part of 2008 , owing to the effects of higher domestic fuel prices, tighter monetary policy, and the expected global slowdown. However, investment is expected to remain strong, in line with rapid credit growth, a booming resource sector, and some improvement in the investment climate.

- Indonesia is better sheltered than many other emerging market economies against a U.S. slowdown. High commodity prices in the WEO baseline and still healthy demand from other emerging countries will continue to boost exports of major commodities. The economy's diversified export base and its lower trade exposure, including indirect links, to the U.S. relative to regional peers, should allow Indonesia to continue to record trade surpluses. Nonetheless, these surpluses are expected to decline over time, reflecting the higher reliance on imported oil as well as higher non-oil imports in line with stronger private investment.

Indonesia: Medium-Term Macroeconomic Framework, 2006-13

\begin{tabular}{|c|c|c|c|c|c|c|}
\hline & 2006 & 2007 & 2008 & 2009 & 2010 & 2013 \\
\hline & \multicolumn{6}{|c|}{ (percentage change) } \\
\hline Real GDP growth & 5.5 & 6.3 & 6.1 & 6.3 & 6.5 & 6.7 \\
\hline Domestic demand & 3.2 & 4.2 & 6.8 & 6.7 & 6.8 & 8.0 \\
\hline Net exports $1 /$ & 1.1 & 0.4 & 0.3 & 0.4 & 0.4 & -0.5 \\
\hline CPI inflation (end period) & 6.6 & 6.6 & 12.0 & 7.5 & 6.5 & 5.0 \\
\hline Saving and investment & \multicolumn{6}{|c|}{ (in percent of GDP) } \\
\hline Gross investment & 23.4 & 22.5 & 23.6 & 24.5 & 25.4 & 28.5 \\
\hline Gross national saving & 26.4 & 25.0 & 25.6 & 25.3 & 25.7 & 27.3 \\
\hline Current account balance & 3.0 & 2.5 & 2.0 & 0.8 & 0.3 & -1.2 \\
\hline Central government balance & -1.0 & -1.2 & -1.9 & -2.1 & -1.8 & -1.9 \\
\hline Central government debt & 39.0 & 35.0 & 31.2 & 29.4 & 27.9 & 25.2 \\
\hline
\end{tabular}

1/ Contribution to GDP growth (percentage points). 
12. At the same time, there are significant external downside risks to growth, and Indonesia could be strongly affected by a deterioration in economic and financial conditions beyond the WEO baseline.

- While relatively less vulnerable to slower U.S. growth, shifts in investor sentiment and financial contagion could be disruptive. Increased global risk aversion, involving substantial deleveraging and repricing of risk, could trigger capital outflows from highbeta and more volatile emerging markets. Staff analysis suggests that, within Asia, Indonesia's financial markets remain relatively sensitive to spillovers from short-term shocks to risk aversion (Box 1).

- A sharp reversal of the rise in commodity prices could pose downside risks to growth. Commodities account for more than half of total exports in Indonesia. Therefore, declines in commodity prices would undermine export revenue, as well as profits and valuations of many commodity producers on the Jakarta stock market. This could also trigger capital outflows, put pressures on the rupiah, and reverse the recent increase in FDI to these sectors. On the positive side, declines in food and oil prices would help ease inflationary pressures and reduce budget subsidies. ${ }^{5}$

13. A continued rise in global oil and food prices, on the other hand, pose a significant risk for the inflation outlook. Food price pressures are expected to ease with an expected strong rice harvest and international prices of many food commodities leveling off. However, price pressures could mount later in the year, especially if the strong rice harvest fails to materialize. ${ }^{6}$

\section{Discussions of Key Policy Challenges}

\section{A. Monetary and Exchange Rate Policies: Responding to Rising Inflation}

14. As in many other countries, inflationary pressures have intensified since the beginning of the year (Figure 4). Headline inflation is expected to reach 12 percent by the end of the year, reflecting the effect of the fuel price adjustment, high food prices, as well as demand pressures.

15. Rising commodity prices have contributed disproportionately to the increase in inflation in Indonesia. Food prices accounted for 49 percent of $y / y$ inflation as of June, compared with a CPI weight of 36 percent. Similarly, the 29 percent fuel price adjustment also significantly raised the headline inflation rate, as did some other commodity prices, such as gold, although to a lesser extent.

\footnotetext{
${ }^{5}$ Annex I describes in more detail the medium-term impact of a possible adverse shock scenario, assuming a stronger global slowdown, a sharp drop in commodity prices, and a surge in risk aversion.

${ }^{6}$ Such a scenario is explored in the accompanying Selected Issues Paper: Inflation Outlook and Monetary Policy Challenges.
} 


\section{Box 1. Financial MARKet SPILlovers: EVIDENCE From RECENT DATA 1/}

Global shocks to risk aversion have a significant impact on Indonesian financial markets. Shocks to the VIX index tend to spill over into Indonesian financial markets within 2-3 days. As expected, the largest impact is on equities, the most risky asset class.

Within Asia, Indonesia's financial markets remain relatively sensitive to such shortterm spillovers. Compared to some important emerging market countries outside the region (e.g., Turkey, South Africa, and Brazil) Indonesian markets appears to be somewhat more stable. Nevertheless, the analysis suggests that Indonesia could be significantly affected by another episode of flight from emerging market assets.
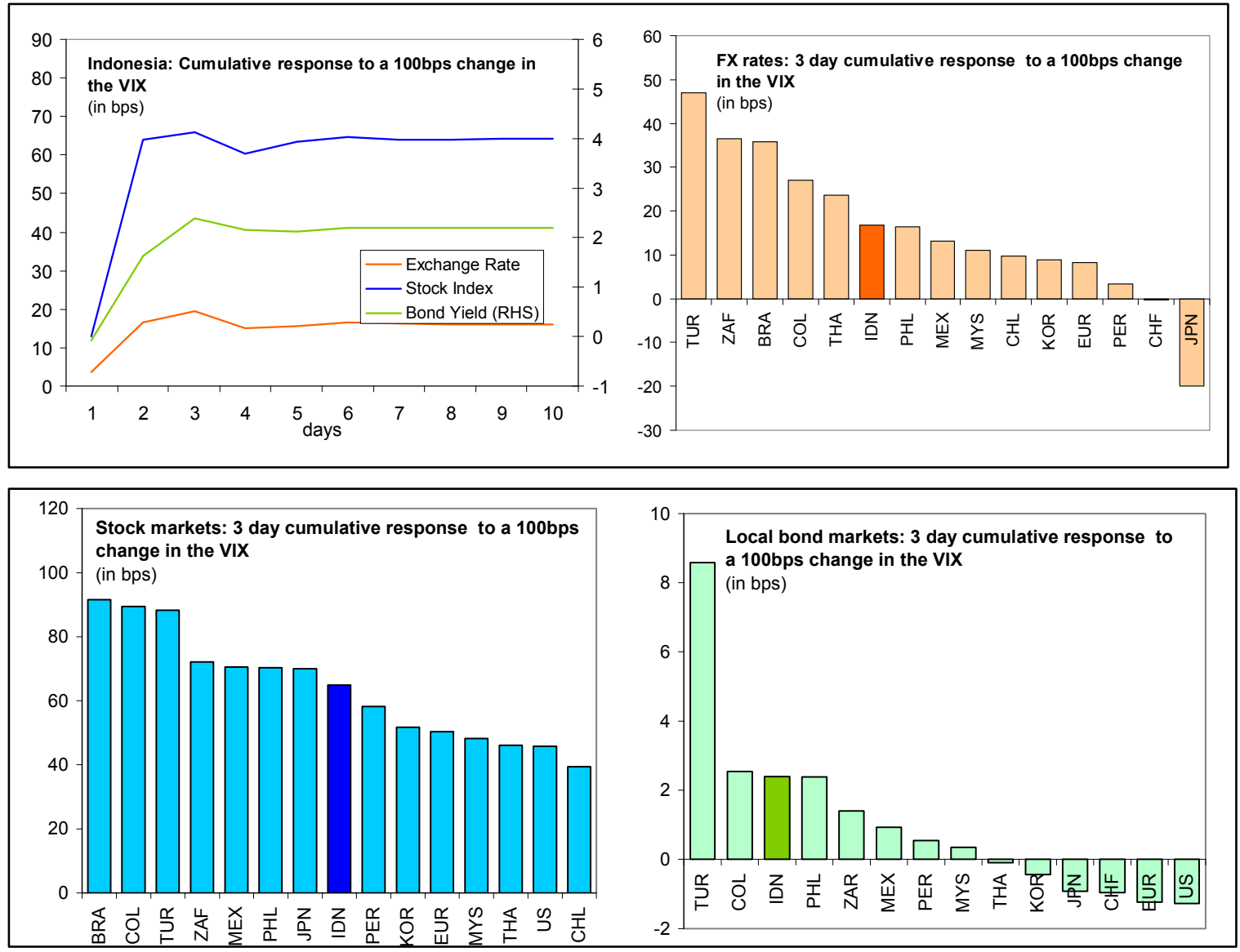

1/ Based on daily data from January 2006 through February 2008. Impulse responses are based on VARs with 2 lags and generalized impulses that are robust the ordering of shocks. 
Figure 4. Indonesia: Inflation and Monetary Developments

Inflation increased substantially in 2008...

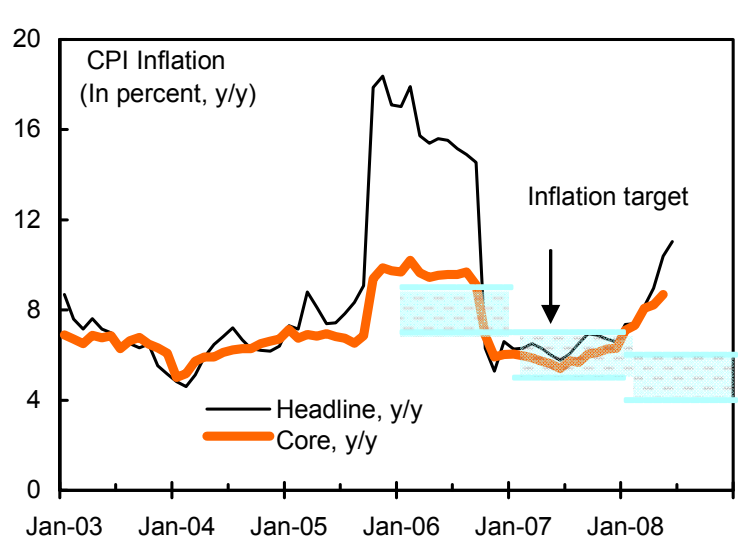

Weakness in the rupiah...

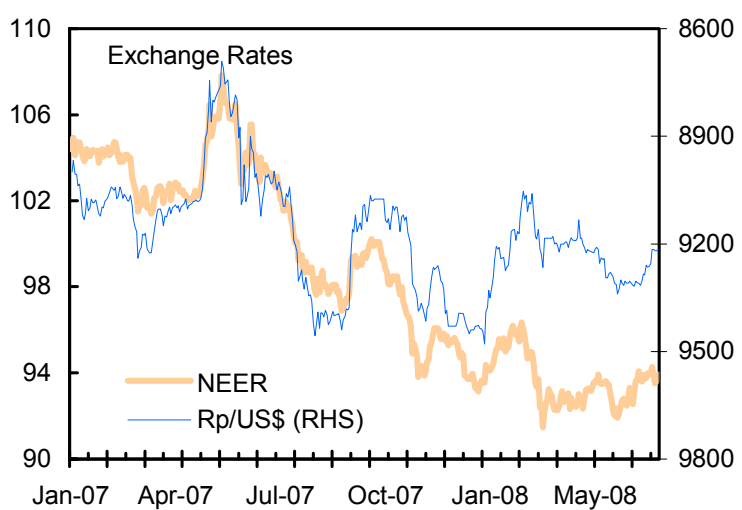

Real interest rates have declined...

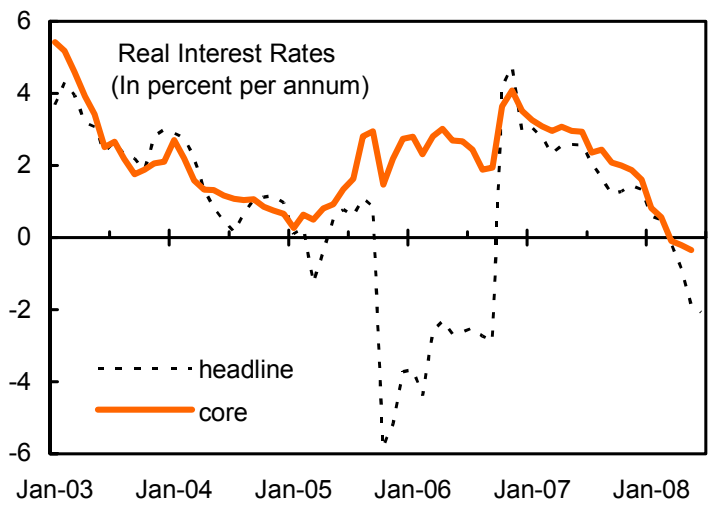

...led by high food prices, but evidend broadly across categories.

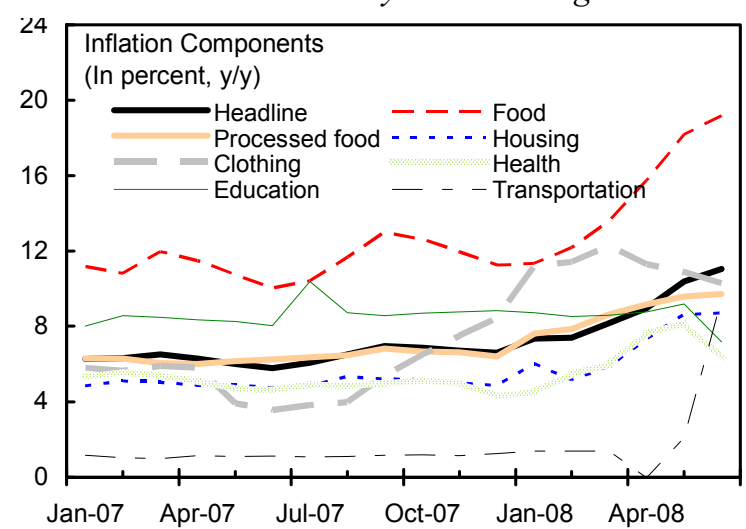

....and strong credit growth have contributed to inflationary pressures.

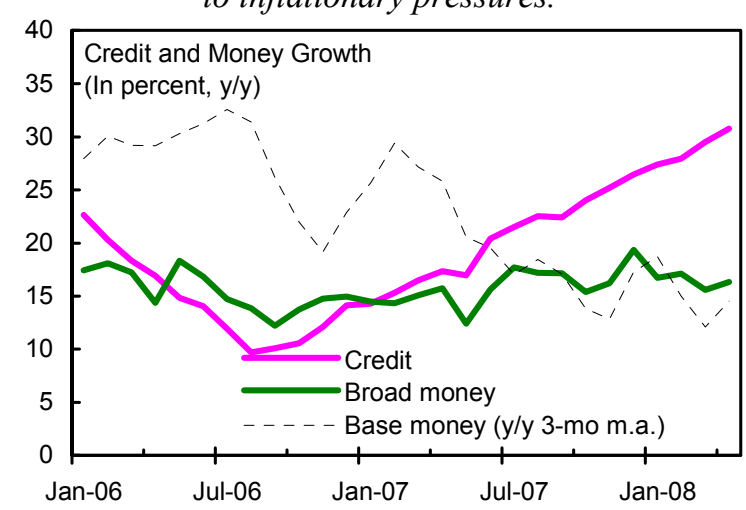

...despite some rate increases since April.

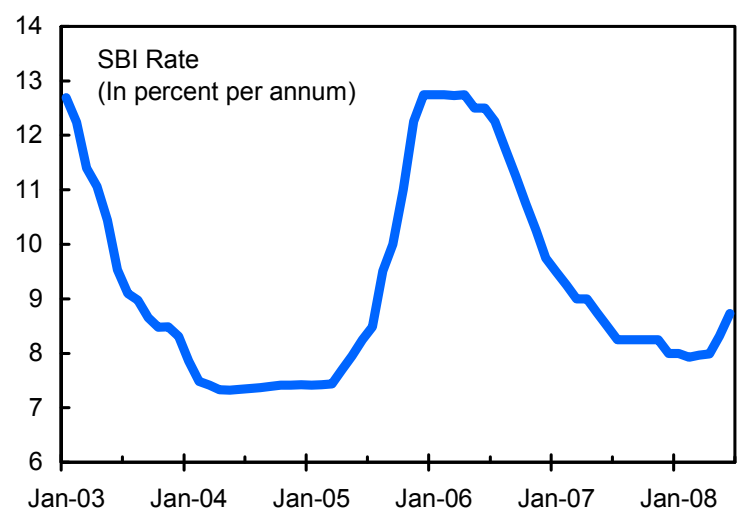

Sources: Country authorities; CEIC Data Co, Ltd.; and Fund staff calculations. 
16. However, strong domestic demand and weakness in the rupiah also contributed to rising inflation. Cross-country monetary comparisons suggest that a number of emerging market central banks with inflation targeting frameworks have responded more aggressively to rising inflationary pressures, looked at in terms of the timing and size of rate hikes as well as the level of real interest rates.

- Rupiah weakness. By end-June, the rupiah had depreciated by about 11.5 percent in nominal effective terms since mid 2007, pushing up imported inflation, although it has remained quite stable in 2008 .

- Closing output gap. Solid estimates of potential output are not available, but the economy has been growing at its fastest pace in 10 years. Despite bottlenecks in transportation and infrastructure, capacity utilization has increased, and the unemployment rate has declined. Real interest rates have been falling steadily since late 2006, contributing to the acceleration of credit growth and domestic demand.
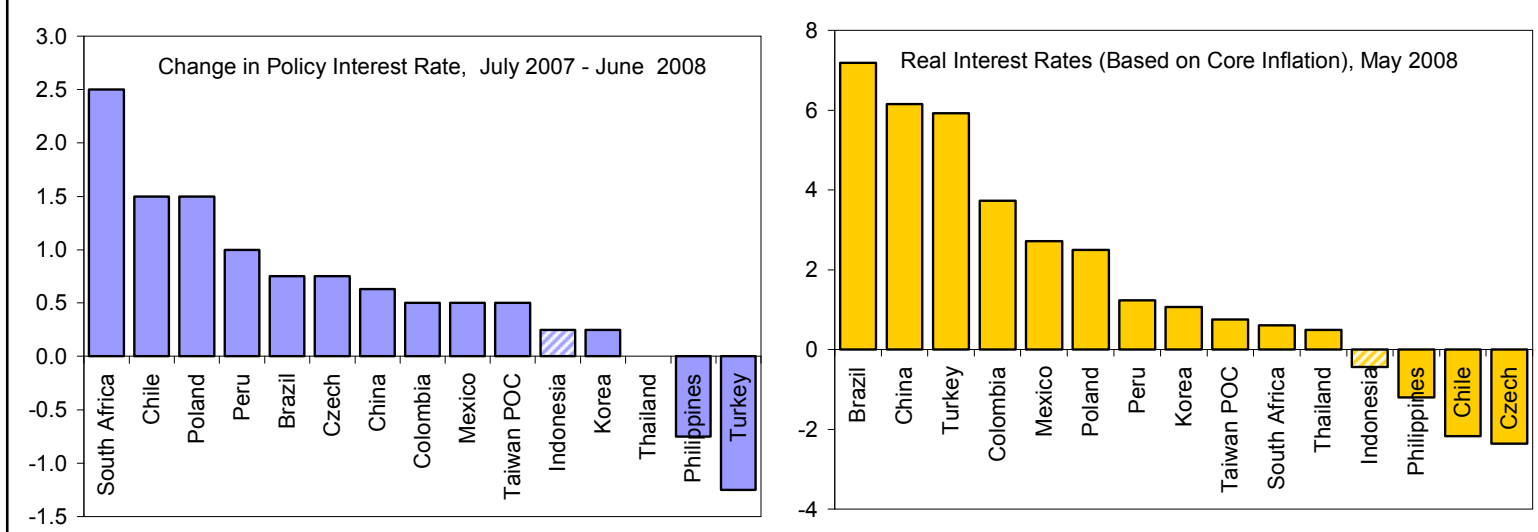

Note: Taiwan POC stands for Taiwan Province of China.

17. BI has begun to tighten monetary policy to address inflationary pressures. The mission suggested that real interest rates would need to be brought to at least a neutral 2-3 percent (based on a 2009 inflation projection of about 71/2 percent), and that this level should be achieved soon to help anchor inflationary expectations. The authorities believe that a real interest rate of about $1 \frac{1}{2}$ percent is neutral and have adopted a more gradual approach, hoping that somewhat smaller rate increases might be sufficient. Nevertheless, they emphasized, and staff agreed, that the extent and pace of tightening will depend on the evolution of domestic economic performance, commodity prices, and the exchange rate.

18. To complement interest rate policy and limit pressure on the rupiah, BI has been "recycling" official foreign exchange receipts to provide liquidity to the foreign exchange market. Higher oil prices boost oil-related revenues and reserve accumulation. Since early 2008, BI has slowed the pace of accumulation of reserves which have increased 
by $\$ 2.5$ billion with respect to the level at end-2007. ${ }^{7}$ Staff supported this policy and suggested that a moderately stronger rupiah would be in line with fundamentals and help support both the external balance and the inflation objective. Model-based estimates suggest that the rupiah remains somewhat undervalued in real effective terms - about 0 to 15 percent, depending on the methodology (Box 2). However, the authorities and staff agreed that there are limits to the recycling policy, and a steady and prolonged decline in reserves should be avoided. Current reserve levels are comfortable and there is no urgency to increase reserves, although over the medium-term higher reserves could reduce vulnerabilities and borrowing costs (see Selected Issues paper on reserve adequacy). To enhance transparency and support foreign exchange market development, the mission suggested that BI could consider an automatic mechanism for "recycling" foreign exchange receipts similar to the one implemented in Mexico, whereby part of the realized reserve accumulation in one quarter is sold during subsequent quarters.

\section{The mission proposed several steps to improve transparency and communication and help anchor inflationary expectations.}

- Inflation forecasts. The mission recommended publishing inflation forecasts (beyond the current year) and discussing monetary policy decisions more explicitly in reference to the inflation forecasts and targets beyond the current year. On the other hand, public statements with regard to specific future interest rate levels and credit growth targets could be less specific.

- Targets. The mission did not recommend changing the 2008 target (the current inflation rate is well outside the target range), given the short time left in the current year. Instead, it would be preferable to provide a forecast and explain the reasons for the deviation. In contrast, a revision of the 2009 and 2010 targets (4.5 \pm 1 and $4.0 \pm 1$, respectively) could be considered with a view to tracing a realistic yet sufficiently ambitious path towards achieving an unchanged medium-term inflation objective of around 3 percent (in line with Indonesia's major trading partners). While revisions to inflation targets should generally be avoided to maintain credibility, in this case, the 2009-10 targets are no longer realistic and in the absence of official multi-year forecasts to guide expectations, more realistic targets that guide monetary policy decisions could help anchor expectations about inflation and monetary policy. However, in its communications strategy, BI should focus more on the medium-term objectives and the measures needed to ensure their achievement. BI broadly agreed and highlighted their commitment to the medium-term objective.

\footnotetext{
${ }^{7}$ The government deposits all foreign exchange receipts (arising from oil-related revenues and external borrowing) with BI. Meanwhile, government purchases of foreign exchange (for external debt service) are much smaller, and the state oil company Pertamina buys foreign exchange for gasoline imports on the open market. This results in sizable reserve accumulation, unless BI sells (recycles) some of those reserves again in the market.
} 


\section{BOX 2. INDONESIA: EXCHANGE RATE ASSESSMENT}

Real Exchange Rate Developments: Indonesia real effective exchange rate (REER) has recovered significantly since the Asian crisis, reaching the most appreciated level in 10 years in mid-2007. More recently, however, some of the appreciation has been reversed with a real depreciation of around 9 percent from May 2007 to April 2008, despite continued improvements in Indonesia's terms of trade.

Estimation of the Equilibrium Exchange Rate: According to two of the three methodologies used by the IMF's Consultative Group on Exchange Rate Issues (CGER), the rupiah may be modestly undervalued relative to the long run equilibrium, in the range of $0-15$ percent. The macroeconomic balances (MB) approach implies that the exchange rate is fairly valued, with the current account (CA) norm estimated to be -0.5 percent of GDP, close to the underlying CA ( -0.1 percent of GDP). The equilibrium real exchange rate (ERER) and the external sustainability approaches suggest an undervaluation of 13 and 15 percent respectively. The increase in the estimated ERER in recent years is primarily due to stronger commodity prices and a rising NFA position. However, some caution is necessary in interpreting these results. In particular, given the assumption of zero misalignment over the sample used in the ERER approach, inclusion of a long pre-crisis period in the sample may lead to an overestimation of the equilibrium ERER.

Export Performance: Despite the modest estimated undervaluation, Indonesia's export market share in global trade dipped slightly in 2007 following the increase from 2004-06, and remains slightly below the 2000 level (by 0.03 percentage points).

Overall Assessment: Econometric estimates suggest that the rupiah may be modestly undervalued. In the near term, there is some room for appreciation which would also contribute to lowering inflation. However, competitiveness challenges remain, as evidenced by the slight fall in export market share since 2000 and by Indonesia's relatively low ranking in investment climate surveys. Over the medium term, Indonesia's modest current account surplus is projected to continue to narrow and eventually give way to a small deficit, consistent with its level of development and the projected strengthening of domestic demand, along with an easing of commodity prices. Given the large improvement in the NFA position and projected current account dynamics, risks to external sustainability are limited.

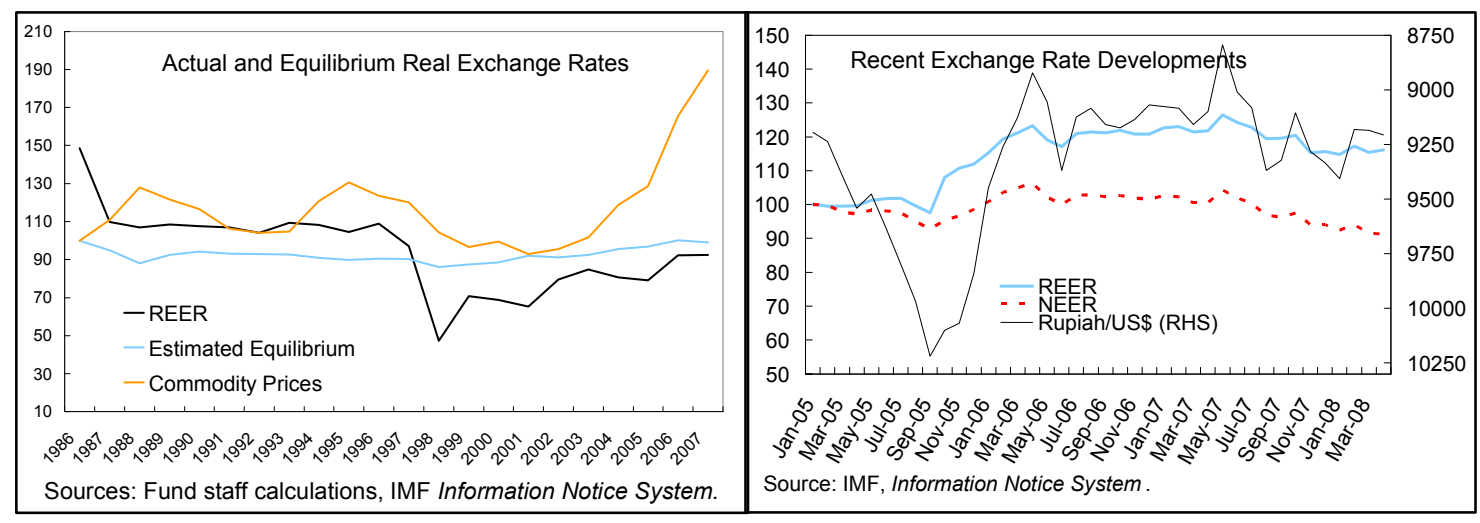


20. BI's changes to the monetary operations framework have been successful and well-received by the markets. BI moved the operational target from the 1 month SBI rate to the overnight interbank rate on June 9. BI had started the transition process early in the year by stepping up fine-tuning operations for liquidity management and conducting SBI auctions through a variable rate tender. This enabled BI to stabilize the overnight rate and move it in line with the one-month SBI rate.

\section{B. Fiscal Policy: Implications and Sustainability of Fuel Subsidies}

\section{Overall, fiscal performance continues to be strong and the 2008 fiscal stance} supports further public debt reduction. The overall fiscal deficit of the central government is foreseen by the staff to be limited to 1.9 percent of GDP for 2008. This would reduce public debt to below 32 percent at end-2008 - in line with the 30-35 percent of GDP target for end-2009, which has provided an anchor for fiscal policy in recent years. This fiscal deficit level is also appropriate to safeguard investment in infrastructure and social expenditures, especially in light of the underspending of recent years and very large infrastructure needs. The government is expecting a slightly lower deficit (1.8 percent of GDP) than contained in the revised budget (2.1 percent of GDP) on account of lower consumption of subsidized domestic fuel. Local/regional governments are expected to continue to accumulate small surpluses in 2008 because of still limited implementation capacity.

\section{However, high energy subsidies} could further reduce the scope for spending on priority areas. These subsidies are likely to account for over one third of central government discretionary spending in 2008 and have led the government to introduce a 10 percent cut on discretionary spending compared to the original 2008 budget. (See Box 3 for a discussion of the impact of oil prices on the budget.)

23. The government has taken steps to limit fuel subsidies. The price increase of May 24 had a positive impact on the budget of about 0.6 percent of GDP and created fiscal space, while reducing smuggling incentives. To limit the burden on the poor, a significant part of this fiscal space is being used on a cash compensation scheme, while the remaining ( 0.3 percent of GDP) will help contain the fiscal deficit. Under this scheme, the government is disbursing monthly cash payments to 19 million households through December 2008, and is expanding its rice distribution program. In addition, as a response to rising food prices, the government has introduced several tax incentives and trade measures aimed at limiting food price increases, such as the reduction of import duties on rice, wheat, and soybeans, as well as VAT exemptions. 


\section{BoX 3. The IMPACT OF OIL PRICES ON THE BUdGeT}

Surging international oil prices have again raised concerns in the markets about the budget impact and sustainability of energy subsidies. Such concerns, in addition to rising inflation, have contributed to the recent government bond sell-off, as well as the widening of Indonesia's CDS and EMBI spreads in relation to peers.

However, considering all oil related revenues and expenditures, the net effect on the budget is relatively small. Oil-related expenditures for the central government arise from fuel and electricity subsidies paid to the state oil company Pertamina and the electricity company PLN, as well as from transfers to the regions based on a revenue sharing formula. However, a large share of those regional transfers is based on budgeted, not actual, oil prices so those transfers only adjust in the next budget year. Oil-related revenues take the form of royalties, income tax, profit sharing agreements and dividends from Pertamina. The latter are usually paid based on the previous year's profits, delaying the impact on the budget by one year, although the government can request advance dividends (as in 2008). The initial combined effect of a $\$ 10 /$ barrel oil price increase on the fiscal deficit is currently estimated at about 0.1 percent of GDP. This increases to about 0.2 percent of GDP in the following fiscal year.

The evolution of subsidized fuel consumption is a key factor determining the fiscal impact. The above estimates assume fuel consumption broadly in line with past trends. However, actual sales of subsidized fuel tend to increase with the gap relative to the international price, likely as a result of smuggling (text figure) and shifts from nonsubsidized to subsidized fuels. A 10 percent increase in the consumption of subsidized products would raise the annual subsidy cost by 0.3 percent of GDP.

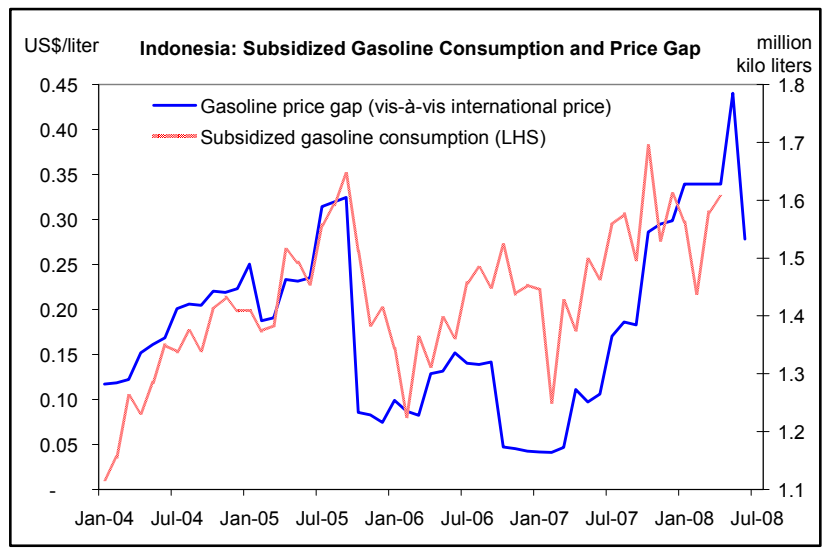

Overall, as long as consumption remains contained, energy subsidies are not a threat to fiscal sustainability, although they do affect the quality of spending. 
24. The authorities noted that further steps will be taken in the future to reduce the cost of fuel subsidies. Despite the recent fuel price increase, energy subsidies remain large (about 5 percent of GDP in 2008). The authorities plan to contain subsidized fuel consumption, possibly by capping purchases of subsidized fuels to certain amounts and through gradual price increases for certain users, such as private cars. Efforts are also underway to replace heavily subsidized kerosene by more economical LPG as the main cooking fuel through supplying the population with free LPG-using stoves.

25. The mission proposed to reintroduce automatic fuel price adjustments, designed to achieve the government's goal of eliminating fuel subsidies over the medium term. Automatic adjustments would ensure that higher global oil prices protect the fiscal position while helping depoliticize the process of fuel price adjustments. The authorities cautioned that automatic adjustments are politically not feasible at this point. The mission noted that further ad-hoc adjustments would also help reduce subsidies, albeit a second best alternative to an automatic adjustment mechanism.

26. Public finance reforms are producing good results. The ongoing reforms are aimed at strengthening revenue collection and public financial management, as well as improving the investment climate by making the tax system more business-friendly. ${ }^{8}$ Comprehensive tax administration reforms, including the roll-out of the small taxpayers offices, are already generating important gains, both in terms of revenue and the investment climate. Progress is being made towards establishing a treasury single account, though completion hinges on resolving various issues with BI including remuneration of government deposits. Encouraging efforts have also continued to be made in improving fiscal transparency, including the publication of a fiscal risk statement in the 2008 budget.

\section{Financial Sector Policies: Implications of the Global Financial Market Turmoil}

27. While Indonesia has so far remained relatively insulated from the global crisis, looking ahead, local markets are vulnerable to higher funding costs, spikes in volatility, and declining risk appetite. Financing pressures have increased for those Indonesian corporates that have access to foreign markets. So far, companies have been able to react by increasing financing from the domestic banking system, but rising policy interest rates and high government bond yields suggest that domestic financing conditions are also likely to tighten somewhat. Meanwhile, exchange rate volatility has remained subdued, but a loss of confidence, including on the part of the local investor base, could exert downward pressure on the rupiah.

\section{However, the banking system should remain relatively resilient, even in the} advent of an adverse macro shock. Stress testing analysis suggests that under a macro scenario where commodity prices fall sharply and global economic growth decelerates, none

\footnotetext{
${ }^{8}$ See Selected Issues Paper: Progress in Fiscal Institution Building.
} 
of the largest 15 banks would see their CARs fall below the 8 percent minimum threshold (Box 4). Banks have gradually reduced their holdings of government bonds as a share of assets (to about 30 percent), while shifting their holdings in the trading portfolio into variable rate securities, and thus are less affected by the rise in policy rates. In addition, strict limits on open FX positions (20 percent of total capital) restrict the direct impact of exchange rate risk. Nevertheless, the mission encouraged BI to continue improving their stress testing framework, including tail risk scenarios and analysis of banks' liquidity risks.

29. The authorities and staff agreed that private sector credit growth will have to be monitored closely. While not representing a threat for macroeconomic stability at this point (the loan to deposit ratio is only 71 percent and private sector credit is equivalent to only about 25 percent of GDP), the rapid acceleration in bank lending, particularly consumer credit and credit in foreign currency, could become a source of vulnerability. ${ }^{9}$ The mission cautioned that, while asset quality has improved, NPLs may be lagging and the current cyclical strength may disguise financial weaknesses. BI should closely scrutinize screening criteria for new and restructured loans and ensure banks are properly provisioned and hedged. Efforts should also focus on improving monitoring of private sector external debt and data coverage of nonbank financial institutions and corporations.

\section{Several prudential regulations have been modified with a view to stimulate}

credit growth. Because of what it perceived as overly restrictive regulations that have unduly limited lending in some areas such as SMEs, BI reduced capital requirements on banks by lowering the risk weights on loans to small and medium enterprise (SME). A similar measure was implemented with respect to corporate bonds, while establishing caps on corporate bond holdings. All these measures are consistent with Basel II and international best practices, but credit concentration limits were raised above international standards. While these measures are not likely to have a major impact on credit, staff noted that credit growth is already expanding at a rapid pace, and there was no need for additional stimulative measures.

\footnotetext{
${ }^{9}$ Supervisors and the business community felt that most of the foreign currency credit is being directed to the commodity sector, which is export-oriented.
} 


\section{BOX 4: STRESS TEST ANALYSIS ON INDONESIA's BANKING SYSTEM}

\section{Sufficient capitalization and strong asset quality should enable Indonesian banks to remain relatively resilient in the event of an adverse macroeconomic shock.}

The banking system remains well-capitalized. As credit growth has increased, the capital adequacy ratio (CAR) and the ratio of Tier 1 capital to assets (leverage ratio) have declined to $18 \%$ and $15 \%$, respectively for the largest 15 banks. However, both still exceed standard thresholds by ample margins (a Tier 1 ratio below 4 percent is considered seriously undercapitalized). The Tier 1 capital ratio is used as an additional metric, since reported CARs are high in Indonesia as a result of zero risk weighting of sizable government bond portfolios. Liquidity is relatively high in Indonesia's banking system and thus not a matter of concern at this point.

The largest 15 banks, representing nearly 70 percent in total assets, were subject to stress tests. The results are based on BI's risk model that links key indicators, such as NPLs, to the main macro variables. Under the baseline macro projections, capitalization ratios and NPLs are expected to remain broadly unchanged (see text table). The banking system was also subject to a more extreme scenario, which assumes that commodity prices fall sharply amid a global economic slowdown (see description of the adverse macro scenario in Annex III). Under this scenario, average Tier 1 and CAR ratios of the banks fell both by 2.6 percentage points each. Most banks would be able to absorb the impact of this extreme but plausible shock. However, one bank would see its Tier 1 capital ratio dip below 4 percent, and two banks would experience a drop in the CAR below the 8 percent threshold.

Sensitivity analysis was also performed to determine the magnitude of shocks required to significantly impact capitalization. Thresholds were determined for key variables affecting credit, interest rate, exchange rate, and market risk. Deterioration in credit quality remains the largest risk. If 24 percent of loans were downgraded to the next lower classification, one bank's Tier 1 capital would fall below 4 percent. It would require fairly large shocks in interest rates, bond prices, or the exchange rate for at least one bank to become seriously undercapitalized.

Overall the banking system should be able to sustain significant stress, owing to its low loan-to-deposit ratio, large share of floating-rate securities, small net open exchange rate position, strong profitability, and high capital cushion. However, credit quality needs to be closely watched, especially in light of rapid credit growth.

\begin{tabular}{lcccc}
\multicolumn{2}{c}{ Stress Test and Sensitivity Analysis for 15 Largest Indonesian Banks } \\
(In percent unless otherwise noted)
\end{tabular}

$1 /$ Assumes a stronger global growth slowdown, a sharp fall in commodity prices, and some capital outflows, triggering lower growth, higher inflation, depreciation of the rupiah, and lower bond and equity prices (see Annex I for details). 
31. The authorities are planning a gradual transition to Basel II between 2008 and 2010. The pace of transition will be differentiated across banks, with smaller banks proceeding at a slower pace. Most of the needed regulations for Pillar I are expected to be completed this year. The mission emphasized that the transition needs to be carefully managed and that efforts should focus on the implementation of Pillar 2, including enhancing day-to-day risk-based supervision at BI and day-to-day risk management at regulated banks. The reduction in capital requirements for certain assets that has taken place under the authorities gradual approach to Basel II, as described in paragraph 30, could lower capital standards of the banking sector. It is, therefore, important to offset these lower risk weights with other higher capital requirements, such as for operational risk, or by increasing loan provisioning.

\section{The current review of the financial safety net should help strengthen the}

institutional framework. Protocols are under discussion to establish clear responsibilities in the event of a crisis. The draft financial safety net law is being discussed between the government and BI in the context of the Financial Stability Forum, with a view to strengthening the legal framework for bank resolution, and the LOLR framework is being assessed to ensure consistency with international best practice. While clear responsibilities are important to support timely responses in case of a crisis, it will also be important to retain sufficient flexibility in the framework to be able to react to potential unexpected conditions.

33. For some time now, the authorities have stated their intention to participate in an FSAP. They recognize that the FSAP would provide useful inputs to guide further financial sector reform but have not committed to a specific timing, highlighting the need for careful preparation to maximize the benefits of the FSAP.

\section{Staff Appraisal}

34. Indonesia's economy has shown resilience in the face of global financial market turmoil and the global slowdown. Sound macroeconomic policies in recent years have improved fundamentals, including lower debt ratios and higher reserves, and thus limited the transmission of adverse shocks. Banks have avoided adverse spillovers from mature markets, due to very low subprime-related exposures, high liquidity in the system, and sufficient capital. Meanwhile, relatively low reliance on external sources and the ready availability of domestic bank financing have enabled corporations to increase investment despite tighter conditions on global capital markets.

35. Growth is expected to remain strong, although there are downside risks. Robust domestic demand and buoyant exports supported by high commodity prices should continue to propel the economy. Nevertheless, downside risks predominate and Indonesia could be affected substantially by a weakening in growth in Asia beyond the WEO baseline, especially if accompanied by slumping commodity prices. In addition, Indonesia's financial markets remain vulnerable to major episodes of global risk aversion and contagion from other emerging markets. These risks underscore the need for prompt policy responses to changing external circumstances. 
36. Continued monetary policy tightening is needed. High food and fuel prices have been the main source of inflationary pressures. However, strong domestic demand, supported by rapid credit growth and low real interest rates, has also contributed. Real interest rates are now negative and also low by cross country comparison, which has likely contributed to the relatively weaker rupiah. BI has appropriately started hiking interest rates, but further increases will be needed promptly to limit second round effects of the fuel price increase and put inflation back on a firmly declining path. Considering the momentum of domestic demand, the resulting effect on growth should be mild and short-lived.

37. Efforts should continue to strengthen the inflation targeting framework. As the 2008 inflation target will clearly be missed, effective communication and a credible strong commitment to the medium-term targets will be important to anchor inflationary expectations and maintain confidence. This should include publishing inflation forecasts and could involve adjusting the 2009-10 targets. The shift of the operational target to the interbank overnight rate has been managed well and should help improve the effectiveness of monetary policy.

38. Indonesia's exchange rate policy is generally appropriate. Staff estimates suggest that the real exchange rate is likely to be somewhat undervalued as a result of improving fundamentals and the recent underperformance of the rupiah in 2007. The new policy of increased reselling of oil receipts should strengthen the currency and help support monetary policy in dampening inflationary pressures. Foreign exchange sales should be managed in a way that does not create perceptions of specific exchange rate targets and should avoid a sustained decrease in reserves. A mechanism with less short-term discretion could be useful in that regard. While reserves are adequate, some additional accumulation over the mediumterm could further reduce vulnerabilities.

\section{The fiscal stance is consistent with a substantial reduction of the public debt} burden, but energy subsidies present a major challenge. The recent fuel price increase was an important step to address this problem, and the accompanying cash transfers to the poor are an effective instrument to cushion the social impact. Cash transfers should also be used to replace the tax incentives and trade measures recently introduced to limit food price increases. While there is a significant risk that subsidies will be higher than planned, there should be enough cushion in the 2008 budget to ensure that the impact on fiscal sustainability and public borrowing requirement is manageable. However, the introduction of preferably an automatic fuel price adjustment mechanism, or ad-hoc fuel price adjustments, would help protect fiscal space for capital and social expenditures and guard against remerging concerns and speculation about the sustainability of subsidies and timing of price adjustments. Because of these uncertainties, there is currently little scope for deploying fiscal policy in the event of a downturn, despite the fundamentally sound position. On public finance reforms, staff continues to support the ongoing agenda and recognizes the impressive results that have already been achieved.

40. With credit growth already expanding at a high rate, financial sector policies should focus on maintaining stability and the soundness of the financial system. Going 
forward, prudential regulations should not be loosened beyond international standards with a view to stimulate credit growth. Instead, standards for new loan approval need to be closely monitored, especially foreign currency credit and consumer credit. Staff supports the planned gradual transition to Basel II, but it will be important to ensure that capital standards for the banking system are not lowered as a result of partial implementation. The review of the financial safety net is welcome and should result in a flexible system that ensures timely responses in case of a crisis. Staff encourages the authorities to confirm a date for the FSAP, as this exercise could help identify areas for further improvement in the financial sector.

\section{Over the medium-term, continued progress on structural reforms is needed to} achieve higher sustainable GDP growth. Staff welcomes progress towards implementing reforms over the past year. While major breakthroughs in key areas such as labor market reform seem unlikely in the run-up to the 2009 elections, recently announced policy packages covering infrastructure, small and medium enterprises, the investment climate, and financial sector signal the authorities intention to press ahead with the structural agenda.

\section{It is recommended that the next Article IV consultation take place on the standard 12-month cycle.}


Table 1. Indonesia: The Authorities' Response to Recent Fund Policy Advice

\begin{tabular}{|c|c|}
\hline Advice from the 2007 Article IV Discussions & Actions Taken \\
\hline $\begin{array}{l}\text { Monetary policy should focus on achieving the } 2008 \\
\text { target. While the rupiah appreciation and moderating } \\
\text { core inflation has opened room for limited interest rate } \\
\text { cuts, BI needs to exercise caution. }\end{array}$ & $\begin{array}{l}\text { Interest rates were left unchanged during } 2007-\mathrm{H} 2 \text {, until a surprise cut of } 25 \\
\text { bp in December, despite rising core inflation and a weaker rupiah. Inflation } \\
\text { met the } 2007 \text { target, but has trended upwards since and reached } \\
10.4 \text { percent recently, above the } 4-6 \text { percent } 2008 \text { target range. In } \\
\text { response, BI raised interest rates by a cumulative } 75 \text { bps in May and July. }\end{array}$ \\
\hline
\end{tabular}

\section{Fiscal policy}

Fiscal deficit targets of 1.8 percent and 1.7 percent of The fiscal deficit in 2007 was 1.2 percent of GDP due to better than expected revenue collection. The 2008 deficit target is consistent with a continued decline in the public debt to GDP ratio.

Fuel price adjustments should be depoliticized by the introduction of a mechanism for automatic

Domestic fuel prices were raised by 29 percent in May 2008. However, prices remain the lowest in the region (at about 30-70 percent of adjustments of energy prices. international spot prices depending on the fuel product).

Create a Single Treasury Account to ensure better fiscal management.

Cash management regulations were approved in July 2007. However, a few outstanding issues continue to impede the establishment of a TSA.

Improve fiscal space through both revenue and expenditure measures (especially reducing untargeted energy subsidies).

No new revenue measures were introduced (a tax policy package has been under discussion in parliament since 2005). The recent fuel price adjustment alleviates pressures on the budget but due to rising oil prices, energy subsidies continue to squeeze priority spending.

Improvements are needed in a number of areas to better assess fiscal risks, including monitoring of SOEs, reporting of quasi-fiscal and extra-budgetary activities and monitoring contingent liabilities.

A statement of fiscal risks and a medium-term fiscal framework were introduced in the 2008 budget.

\section{Financial sector}

$\mathrm{BI}$ should reconsider the appropriateness of the relaxation in prudential regulations to encourage lending.

A deeper non-bank financial sector could be a significant source of long-term financing.

There has been no reversal of previous regulation.

A strategy on the future role of state banks is needed. An explicit strategy has not yet been developed.

The Sharia Banking Bill was approved by parliament on April. Efforts to develop the government securities market were made, including the reintroduction of T-bills auction and a decree on the Dealer System. The latest policy package includes various measures in support financial sector development.

The authorities should participate in an FSAP.

The authorities have agreed in principle to participate in an FSAP, but have yet to commit to a date.

\section{Structural reforms}

Focus on increased infrastructure spending, including by facilitating public-private partnerships, and improve business climate.

Investment has picked up over the past year. The government revised its negative list (indicating sectors with limitations on foreign investment) at end-2007. The list improves clarity for foreign investors.

Improve flexibility in the labor market.

No progress has been made on this area. 
Table 2. Indonesia: Selected Economic Indicators, 2005-09

Nominal GDP (2007): 3,801 trillions rupiah or 433 billions U.S. dolla

Main exports (percent of total, 2007): mineral fuels (26), manufactured goods (17), machinery and transport equipment (13)

GDP per capita (2007): 1,925 U.S. dollar

Unemployment rate (2008): 8.5

FDI (2007, net): 1,2 U.S. billions dollar

Public debt (2007, gross): 35 percent of GDP

Foreign public debt (2007): 14.4 percent of GDP

Poverty headcount ratio at national poverty line (2008): 15.4 percent of population

\begin{tabular}{|c|c|c|c|c|c|}
\hline & 2005 & 2006 & 2007 & 2008 & 2009 \\
\hline & \multicolumn{3}{|c|}{ Act. } & \multicolumn{2}{|c|}{ Proj. } \\
\hline Real GDP (percent change) & 5.7 & 5.5 & 6.3 & 6.1 & 6.3 \\
\hline Domestic demand & 5.3 & 3.2 & 4.2 & 6.8 & 6.7 \\
\hline \multicolumn{6}{|l|}{ Of which: } \\
\hline Private consumption & 4.0 & 3.2 & 5.0 & 5.1 & 5.1 \\
\hline Gross fixed investment & 10.8 & 2.5 & 9.2 & 11.0 & 10.4 \\
\hline Change in stocks $1 /$ & -0.4 & -0.3 & -1.5 & 0.1 & 0.0 \\
\hline Net exports $1 /$ & 1.1 & 1.1 & 0.4 & 0.3 & 0.4 \\
\hline Statistical discrepancy $1 /$ & -0.3 & 1.5 & 2.2 & -0.2 & 0.0 \\
\hline \multicolumn{6}{|l|}{ Saving and investment (in percent of GDP) } \\
\hline Gross investment 2/ & 23.5 & 23.4 & 22.5 & 23.6 & 24.5 \\
\hline Gross national saving & 23.6 & 26.4 & 25.0 & 25.6 & 25.3 \\
\hline Foreign saving (external current account balance) & -0.1 & -3.0 & -2.5 & -2.0 & -0.8 \\
\hline \multicolumn{6}{|l|}{ Prices (12-month percent change) } \\
\hline Consumer prices (end period) & 17.1 & 6.6 & 6.6 & 12.0 & 7.5 \\
\hline Consumer prices (period average) & 10.5 & 13.1 & 6.4 & 10.6 & 8.7 \\
\hline \multicolumn{6}{|l|}{ Public finances (in percent of GDP) } \\
\hline Central government revenue & 17.8 & 19.0 & 17.8 & 20.4 & 20.1 \\
\hline Central government expenditure & 18.1 & 19.9 & 19.1 & 22.4 & 22.2 \\
\hline Central government balance & -0.3 & -1.0 & -1.2 & -1.9 & -2.1 \\
\hline Primary balance & 2.1 & 1.4 & 0.8 & 0.2 & -0.2 \\
\hline Central government debt & 45.6 & 39.0 & 35.0 & 31.2 & 29.4 \\
\hline \multicolumn{6}{|c|}{ Money and credit (12-month percent change; end of period) } \\
\hline Rupiah M2 & 13.0 & 18.1 & 19.1 & 18.5 & $\ldots$ \\
\hline Base money & 21.9 & 22.2 & 27.8 & 18.3 & 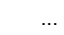 \\
\hline Private sector credit & 19.0 & 14.9 & 23.3 & 24.2 & $\ldots$ \\
\hline One-month SBI rate (period average) & 9.1 & 11.8 & 8.6 & 8.9 & $\ldots$ \\
\hline \multicolumn{6}{|l|}{ Balance of Payments (in billions of US\$) } \\
\hline Oil and gas (net) & 4.2 & 6.8 & 6.0 & 2.7 & -0.1 \\
\hline Non-oil exports (f.o.b) & 66.8 & 80.6 & 93.1 & 109.9 & 113.4 \\
\hline Non-oil imports (f.o.b) & -53.4 & -57.7 & -66.1 & -78.7 & -83.6 \\
\hline Current account balance & 0.3 & 10.8 & 11.0 & 9.8 & 4.2 \\
\hline Foreign direct investment & 5.3 & 2.2 & 1.8 & 2.7 & 3.4 \\
\hline Overall balance & -0.5 & 14.5 & 13.2 & 6.2 & 6.4 \\
\hline \multicolumn{6}{|l|}{ Gross reserves } \\
\hline In billions of U.S. dollars (end period) & 34.7 & 42.6 & 56.9 & 63.4 & 69.7 \\
\hline In months of imports & 4.4 & 4.7 & 5.1 & 5.1 & 5.3 \\
\hline As a percent of short-term debt $3 /$ & 103.0 & 147.8 & 159.9 & 213.4 & 246.9 \\
\hline \multicolumn{6}{|l|}{ Total external debt } \\
\hline In billions of U.S. dollars & 133.8 & 129.5 & 137.4 & 140.8 & 143.4 \\
\hline In percent of GDP & 46.6 & 35.5 & 31.7 & 28.3 & 25.5 \\
\hline \multicolumn{6}{|l|}{ Net International Investment Position } \\
\hline In billions of U.S. dollars & -127 & -139 & $\ldots$ & $\ldots$ & $\ldots$ \\
\hline In percent of GDP & -44 & -38 & $\ldots$ & $\ldots$ & $\ldots$ \\
\hline \multicolumn{6}{|l|}{ Exchange rate (period average) } \\
\hline Rupiah per US\$ & 9,705 & 9,165 & 9,141 & $\ldots$ & . \\
\hline Nominal effective exchange rate (Jan. $2000=100$ ) & 79.3 & 83.7 & 80.9 & $\ldots$ & .. \\
\hline \multicolumn{6}{|l|}{ Memorandum items: } \\
\hline Oil production (000bcpd) & 999 & 956 & 899 & 927 & 955 \\
\hline Indonesian oil price (US\$/bbl) & 51.8 & 63.9 & 70.7 & 116.1 & 124.6 \\
\hline Nominal GDP (in trillions of Rupiah) & 2,785 & 3,339 & 3,957 & 4,642 & 5,366 \\
\hline Nominal GDP (in billions of US\$) & 287 & 364 & 433 & 500 & 565 \\
\hline
\end{tabular}

Sources: Data provided by the Indonesian authorities; and Fund staff estimates.

1/ Contribution to GDP growth (percentage points)

2/ Includes changes in stocks. Computed on real basis.

3/ Short-term debt on a remaining maturity basis. 
Table 3. Indonesia: Selected Social Indicators, 2002-2007

\begin{tabular}{|c|c|c|c|c|c|c|}
\hline & 2002 & 2003 & 2004 & 2005 & 2006 & 2007 \\
\hline \multicolumn{7}{|l|}{ Education } \\
\hline Elementary school net enrollment ratio, \% of relevant aged group & 96.1 & 96.4 & 96.8 & 97.1 & 97.4 & 97.6 \\
\hline Population > 10 yr old not completed primary school (\%) & 24.1 & 21.9 & 15.3 & 21.5 & 20.8 & $\ldots$ \\
\hline Population > 10 yr old finished primary and Junior high school (\%) & 49.2 & 50.1 & 52.0 & 49.4 & 49.2 & $\ldots$ \\
\hline Population $>10$ yr old finished high school $(\%)$ & 19.5 & 19.6 & 23.7 & 21.3 & 22.6 & $\ldots$ \\
\hline Adult literacy rate & 90.7 & 90.9 & 91.5 & 91.9 & 92.4 & 92.5 \\
\hline \multicolumn{7}{|l|}{ Health } \\
\hline Life expectancy rate & 66.5 & 66.2 & 68.6 & 67.8 & 68.2 & 69.1 \\
\hline Fertility rate, births per woman & 2.4 & 2.4 & 2.3 & 2.3 & 2.2 & $\ldots$ \\
\hline Children $<5$ yr old that have good nutrition $(\%)$ & 71.9 & 69.6 & 74.4 & 91.2 & $\ldots$ & $\ldots$ \\
\hline Children $<5$ yr old that had been immunized ( $\%$, measles) & 72.0 & 72.0 & 77.2 & 72.5 & 78.2 & $\ldots$ \\
\hline \multicolumn{7}{|l|}{ Housing and Sanitation } \\
\hline Household with access to piped water (\%) & 19.7 & 18.9 & 20.4 & 22.1 & 22.8 & $\ldots$ \\
\hline Household with electricity (\%) & 87.6 & 87.9 & 89.0 & $\ldots$ & 90.6 & $\ldots$ \\
\hline \multicolumn{7}{|l|}{ Poverty and inequality } \\
\hline Number of people under poverty line (million) & 38.4 & 37.3 & 36.1 & 35.1 & 39.3 & 37.2 \\
\hline Population under poverty line (\%) & 18.2 & 17.4 & 16.7 & 16.0 & 17.8 & 16.6 \\
\hline Gini Coefficient & 0.34 & 0.32 & 0.33 & 0.33 & 0.36 & 0.36 \\
\hline \multicolumn{7}{|l|}{ Employment } \\
\hline Total labor force (millions) & 99 & 101 & 100 & 104 & 106 & 106 \\
\hline Labor participation rate & 67.8 & 65.7 & 67.6 & 66.8 & 66.2 & 67.0 \\
\hline Unemployment rate & 9.1 & 9.5 & 9.9 & 11.2 & 10.3 & 9.1 \\
\hline
\end{tabular}

Sources: Country authorities; World Bank, World Development Indicators; and CEIC Data Co, Ltd. 
Table 4. Indonesia: Balance of Payments, 2006-13

(In billions of U.S. dollars)

\begin{tabular}{|c|c|c|c|c|c|c|c|c|}
\hline & $\begin{array}{r}2006 \\
\text { Act. }\end{array}$ & $\begin{array}{r}2007 \\
\text { Act. }\end{array}$ & $\begin{array}{c}2008 \\
\text { Proj. }\end{array}$ & $\begin{array}{c}2009 \\
\text { Proj. }\end{array}$ & $\begin{array}{c}2010 \\
\text { Proj. }\end{array}$ & $\begin{array}{l}2011 \\
\text { Proj. }\end{array}$ & $\begin{array}{c}2012 \\
\text { Proj. }\end{array}$ & $\begin{array}{c}2013 \\
\text { Proj. }\end{array}$ \\
\hline I. Current account & 10.8 & 11.0 & 10.0 & 4.1 & 1.8 & -3.3 & -6.7 & -11.9 \\
\hline A. Goods, net (trade balance) & 29.7 & 33.1 & 33.9 & 29.7 & 29.0 & 25.7 & 24.1 & 21.0 \\
\hline 1. Exports, f.o.b. & 103.5 & 118.0 & 145.3 & 150.7 & 156.9 & 162.6 & 171.1 & 178.9 \\
\hline Of which: Oil and gas & 23.0 & 24.9 & 35.5 & 37.3 & 39.4 & 38.8 & 38.9 & 37.8 \\
\hline Non-oil and gas & 80.6 & 93.1 & 109.9 & 113.4 & 117.5 & 123.8 & 132.2 & 141.1 \\
\hline 2. Imports, f.o.b. & -73.9 & -84.9 & -111.5 & -121.0 & -127.9 & -136.9 & -147.0 & -157.9 \\
\hline Of which: Oil and gas & -16.2 & -18.8 & -32.8 & -37.4 & -39.3 & -42.0 & -44.8 & -47.9 \\
\hline Non-oil and gas & -57.7 & -66.1 & -78.7 & -83.6 & -88.6 & -94.9 & -102.2 & -110.0 \\
\hline B. Services, net & -9.9 & -11.1 & -12.1 & -12.9 & -13.5 & -14.3 & -15.0 & -15.8 \\
\hline C. Income, net & -13.8 & -15.9 & -16.8 & -17.9 & -19.1 & -20.3 & -21.7 & -23.2 \\
\hline D. Current transfers, net & 4.9 & 4.9 & 5.1 & 5.2 & 5.4 & 5.7 & 5.9 & 6.1 \\
\hline II. Capital and financial account & 2.9 & 2.8 & -3.5 & 2.2 & 6.2 & 10.1 & 14.2 & 19.1 \\
\hline A. Capital account & 0.4 & 0.5 & 0.2 & 0.2 & 0.2 & 0.2 & 0.2 & 0.2 \\
\hline B. Financial account & 2.6 & 2.2 & -3.7 & 2.0 & 6.0 & 9.9 & 14.0 & 18.9 \\
\hline 1. Direct investment, net & 2.2 & 1.2 & 2.7 & 3.4 & 4.0 & 4.5 & 5.2 & 5.7 \\
\hline a. Abroad, net & -2.7 & -4.4 & -4.5 & -4.6 & -4.7 & -4.7 & -4.7 & -4.8 \\
\hline b. In Indonesia (FDI), net & 4.9 & 5.6 & 7.2 & 8.0 & 8.7 & 9.2 & 10.0 & 10.5 \\
\hline 2. Portfolio investment, net & 4.2 & 7.0 & 4.6 & 5.7 & 6.7 & 7.6 & 8.5 & 9.1 \\
\hline a. Assets, net & -1.9 & -3.0 & -3.5 & -3.6 & -3.8 & -3.9 & -4.1 & -4.2 \\
\hline b. Liabilities & 6.1 & 10.0 & 8.2 & 9.3 & 10.5 & 11.5 & 12.6 & 13.3 \\
\hline Equity securities & 1.9 & 3.6 & 2.0 & 2.8 & 3.7 & 4.6 & 5.4 & 6.1 \\
\hline Debt securities & 4.2 & 6.4 & 6.2 & 6.5 & 6.7 & 6.9 & 7.1 & 7.2 \\
\hline 3. Other investment & -3.8 & -5.9 & -11.1 & -7.1 & -4.6 & -2.1 & 0.3 & 4.1 \\
\hline Nonfinancial public sector & -2.5 & -2.4 & -1.0 & -1.7 & -1.0 & -1.1 & -1.3 & -1.2 \\
\hline Disbursements & 3.6 & 4.0 & 5.3 & 4.5 & 4.3 & 4.1 & 3.8 & 3.8 \\
\hline Repayments & -6.1 & -6.4 & -6.3 & -6.2 & -5.3 & -5.2 & -5.1 & -5.0 \\
\hline Banking sector & 0.4 & 0.1 & 0.0 & 0.1 & 0.2 & 0.2 & 0.2 & 0.2 \\
\hline Disbursements & 1.5 & 1.1 & 1.0 & 1.2 & 1.4 & 1.5 & 1.6 & 1.7 \\
\hline Repayments & -1.1 & -1.0 & -1.0 & -1.1 & -1.2 & -1.3 & -1.4 & -1.4 \\
\hline Corporate sector & -0.8 & 1.1 & -0.4 & 0.5 & 0.1 & -0.2 & -0.6 & -0.9 \\
\hline Disbursements & 6.0 & 8.1 & 7.6 & 8.1 & 8.7 & 9.2 & 9.9 & 10.5 \\
\hline Repayments & -6.8 & -7.0 & -8.1 & -7.6 & -8.5 & -9.4 & -10.4 & -11.4 \\
\hline Other $1 /$ & -0.9 & -4.8 & -9.6 & -6.0 & -4.0 & -1.0 & 1.9 & 6.0 \\
\hline III. Total (I+II) & 13.8 & 13.8 & 6.4 & 6.3 & 8.1 & 6.9 & 7.5 & 7.2 \\
\hline IV. Errors and omissions & 0.7 & -1.2 & 0.0 & 0.0 & 0.0 & 0.0 & 0.0 & 0.0 \\
\hline V. Overall balance (III+IV) & 14.5 & 12.5 & 6.4 & 6.3 & 8.1 & 6.9 & 7.5 & 7.2 \\
\hline VI. Reserves and related items & -14.5 & -12.5 & -6.4 & -6.3 & -8.1 & -6.9 & -7.5 & -7.2 \\
\hline Changes in reserve assets & -6.9 & -12.5 & -6.4 & -6.3 & -8.1 & -6.9 & -7.5 & -7.2 \\
\hline \multicolumn{9}{|l|}{ Memorandum items: } \\
\hline Reserve assets position (eop) & 42.6 & 56.9 & 63.4 & 69.7 & 77.8 & 84.6 & 92.2 & 99.4 \\
\hline in months of imports of goods and services & 4.7 & 5.0 & 5.1 & 5.3 & 5.6 & 5.7 & 5.8 & 6.0 \\
\hline in percent of short-term debt & 148 & 150 & 213 & 247 & 282 & 334 & 361 & 213 \\
\hline Current account (percent of GDP) & 3.0 & 2.5 & 2.0 & 0.7 & 0.3 & -0.5 & -0.9 & -1.4 \\
\hline
\end{tabular}

Sources: Data provided by the Bank Indonesia; and Fund staff estimates.

1/ Includes unrecorded capital flows and exceptional financing. 
Table 5. Indonesia: Monetary Survey, December 2005 to December 2008

(In trillions of rupiah, unless otherwise indicated, end of period) 1/

\begin{tabular}{|c|c|c|c|c|c|c|c|}
\hline & \multirow{3}{*}{$\begin{array}{r}2005 \\
\text { Dec } \\
\text { Act. }\end{array}$} & \multirow{3}{*}{$\begin{array}{r}2006 \\
\text { Dec } \\
\text { Act. }\end{array}$} & \multicolumn{4}{|c|}{2007} & \multirow{3}{*}{$\begin{array}{r}2008 \\
\text { Dec } \\
\text { Proj. }\end{array}$} \\
\hline & & & Mar & Jun & Sep & $\mathrm{Dec}$ & \\
\hline & & & Act. & Act. & Act. & Act. & \\
\hline \multicolumn{8}{|l|}{ Monetary Survey } \\
\hline Net foreign assets & 301.0 & 402.9 & 440.1 & 482.9 & 499.1 & 491.5 & 558.5 \\
\hline (in billions of U.S. dollars) & 33.4 & 44.8 & 48.9 & 53.7 & 55.5 & 54.6 & 62.1 \\
\hline Net domestic assets & 886.3 & 979.4 & 933.3 & 967.9 & 1009.9 & 1142.6 & 1377.9 \\
\hline Net claims on government & 496.4 & 501.8 & 443.6 & 426.6 & 435.9 & 493.2 & 493.5 \\
\hline Claims on business sector & 728.4 & 837.2 & 843.9 & 908.4 & 959.1 & 1032.5 & 1282.5 \\
\hline Rupiah claims & 615.6 & 689.1 & 691.6 & 744.1 & 787.9 & 839.1 & 1085.1 \\
\hline Foreign exchange claims & 112.8 & 148.1 & 152.4 & 164.3 & 171.2 & 193.4 & 197.3 \\
\hline Other items (net) & -338.6 & -359.7 & -354.3 & -367.1 & -385.2 & -383.1 & -398.1 \\
\hline Broad money (M2) & 1187.3 & 1382.3 & 1373.4 & 1450.8 & 1508.9 & 1634.1 & 1936.4 \\
\hline Rupiah M2 & 1014.3 & 1198.1 & 1190.7 & 1239.4 & 1295.3 & 1427.3 & 1691.3 \\
\hline Currency in circulation & 124.3 & 151.0 & 129.6 & 146.7 & 160.3 & 183.4 & 217.4 \\
\hline Deposits & 890.0 & 1047.1 & 1061.1 & 1092.7 & 1135.0 & 1243.9 & 1473.9 \\
\hline Foreign exchange deposits & 173.0 & 184.1 & 182.7 & 211.4 & 213.6 & 206.8 & 245.1 \\
\hline \multicolumn{8}{|l|}{ Bank Indonesia } \\
\hline Net international reserves & 223.6 & 353.2 & 393.1 & 424.7 & 434.0 & 458.8 & 556.8 \\
\hline Net domestic assets $2 / 3 /$ & 19.6 & -56.1 & -120.9 & -134.9 & -123.7 & -79.3 & -107.8 \\
\hline Net claims on government & 236.3 & 261.2 & 196.4 & 182.8 & 181.1 & 244.6 & 244.9 \\
\hline Claims on business sector & 25.9 & 25.8 & 25.8 & 25.8 & 25.8 & 14.2 & 14.2 \\
\hline Claims on DMBs & -92.8 & -214.4 & -220.1 & -237.1 & -227.1 & -266.0 & -314.8 \\
\hline Open market operations & -121.2 & -242.0 & -247.5 & -264.3 & -254.1 & -281.2 & -329.9 \\
\hline Other items (net) & -149.8 & -128.7 & -122.9 & -106.4 & -103.4 & -72.2 & -52.2 \\
\hline Base money & 243.2 & 297.1 & 272.2 & 289.7 & 310.3 & 379.6 & 449.0 \\
\hline Currency in circulation & 124.3 & 151.0 & 129.6 & 146.7 & 160.3 & 183.4 & 217.4 \\
\hline DMBs & 118.5 & 146.0 & 142.4 & 142.7 & 149.6 & 195.8 & 231.4 \\
\hline Nonbank deposits & 0.4 & 0.1 & 0.2 & 0.3 & 0.3 & 0.3 & 0.3 \\
\hline \multicolumn{8}{|l|}{ Memorandum items: } \\
\hline NIR of BI (in billions of US\$) & 24.8 & 39.2 & 43.7 & 47.2 & 48.2 & 51.0 & 61.9 \\
\hline Money multiplier (rupiah M2) & 4.2 & 4.0 & 4.4 & 4.3 & 4.2 & 3.8 & 3.8 \\
\hline Base money velocity 4/ & 12.5 & 11.8 & 13.5 & 13.3 & 13.3 & 11.0 & 10.3 \\
\hline Rupiah broad money velocity 4 / & 3.0 & 2.9 & 3.1 & 3.1 & 3.2 & 2.9 & 2.7 \\
\hline \multicolumn{8}{|l|}{ Annual percentage change: } \\
\hline Broad money (constant exchange rate) & 15.3 & 16.4 & 14.3 & 16.4 & 14.0 & 18.2 & 18.5 \\
\hline Rupiah broad money & 13.0 & 18.1 & 16.8 & 15.9 & 13.6 & 19.1 & 18.5 \\
\hline Base money & 21.9 & 22.2 & 20.1 & 17.9 & 12.7 & 27.8 & 18.3 \\
\hline Private sector claims & 19.0 & 14.9 & 14.2 & 19.4 & 20.2 & 23.3 & 24.2 \\
\hline
\end{tabular}

Sources: Data provided by the Bank Indonesia; and Fund staff estimates.

1/ All foreign currency denominated components are valued at a constant exchange rate.

2/ The introduction of a 9-digit system of accounts at BI in May 2004 resulted in a reclassification of some government accounts from other items net to net claims on government.

3/ As part of the BLBI resolution, Bl's net claims on government were reduced by Rp 20.2 trillion (reflected in the figure for 2003). Bl's capital reserves (under other items net) have been reduced by a corresponding amount.

4/ Calculated using end-period quarterly GDP, annualized. 
Table 6. Indonesia: Summary of Central Government Operations, 2005-08

\begin{tabular}{|c|c|c|c|c|c|c|c|c|c|}
\hline & 2005 & 2006 & \multicolumn{3}{|c|}{2007} & \multicolumn{4}{|c|}{2008} \\
\hline & Act. & Act. & April & $\begin{array}{l}\text { Rev. } \\
\text { Budg }\end{array}$ & Est. & April & Budget & Rev. Bud & $\begin{array}{l}\text { Staff } \\
\text { Proj. }\end{array}$ \\
\hline & \multicolumn{9}{|c|}{ (In percent of GDP) } \\
\hline Revenues and grants & 17.9 & 19.0 & 4.1 & 18.0 & 17.8 & 5.5 & 18.1 & 20.0 & 20.4 \\
\hline Oil and gas revenues & 5.0 & 6.0 & 0.6 & 3.8 & 4.3 & 1.3 & 3.7 & 5.3 & 6.4 \\
\hline Non-oil and gas revenues & 12.8 & 12.9 & 3.5 & 14.2 & 13.5 & 4.2 & 14.4 & 14.6 & 14.0 \\
\hline Tax revenues & 11.2 & 11.0 & 3.2 & 11.9 & 11.3 & 3.8 & 12.8 & 12.4 & 11.9 \\
\hline Nontax revenues $1 /$ & 1.6 & 1.9 & 0.3 & 2.3 & 2.2 & 0.3 & 1.6 & 2.2 & 2.0 \\
\hline Grants & 0.0 & 0.1 & 0.0 & 0.1 & 0.0 & 0.0 & 0.0 & 0.1 & 0.0 \\
\hline Expenditure and net lending & 18.2 & 19.9 & 3.9 & 19.6 & 19.1 & 4.1 & 19.8 & 22.1 & 22.4 \\
\hline Current expenditure & 11.1 & 10.1 & 1.7 & 9.9 & 9.7 & 2.2 & 9.6 & 11.8 & 12.5 \\
\hline Personnel & 2.0 & 2.2 & 0.7 & 2.6 & 2.3 & 0.7 & 3.0 & 2.3 & 2.3 \\
\hline Subsidies & 4.4 & 3.2 & 0.3 & 2.8 & 3.8 & 0.8 & 2.3 & 5.2 & 6.0 \\
\hline Of which: Energy subsidies & 3.4 & 1.9 & 0.2 & 1.5 & 3.0 & 0.8 & 1.8 & 4.2 & 5.0 \\
\hline Interest 2/ & 2.4 & 2.4 & 0.6 & 2.3 & 2.0 & 0.5 & 2.1 & 2.1 & 2.1 \\
\hline Other & 2.3 & 2.4 & 0.2 & 2.3 & 1.7 & 0.2 & 2.2 & 2.1 & 2.0 \\
\hline Development expenditure 3/ & 2.3 & 3.1 & 0.3 & 3.0 & 2.9 & 0.4 & 3.8 & 3.8 & 3.5 \\
\hline Transfers to regions & 5.4 & 6.8 & 1.8 & 6.6 & 6.4 & 1.5 & 6.5 & 6.5 & 6.4 \\
\hline Overall balance & -0.3 & -1.0 & 0.3 & -1.6 & -1.2 & 1.4 & -1.7 & -2.1 & -1.9 \\
\hline Financing & 0.3 & 1.0 & -0.3 & 1.6 & 1.2 & -1.4 & 1.7 & 2.1 & 1.9 \\
\hline Domestic & -0.6 & 1.0 & -0.3 & 1.6 & 1.5 & -1.8 & 1.5 & 1.8 & 1.3 \\
\hline Bank financing & -0.6 & 0.5 & -0.9 & 0.3 & 0.4 & -2.1 & 0.0 & -0.3 & 0.0 \\
\hline Net issuance of government securities & -0.1 & 0.5 & 0.6 & 1.3 & 1.1 & 0.3 & 1.6 & 2.1 & 1.3 \\
\hline Recovery of bank assets 4 / & 0.2 & 0.1 & 0.0 & 0.0 & 0.1 & 0.0 & 0.0 & 0.1 & 0.0 \\
\hline Privatization of nonfinancial assets & 0.0 & 0.0 & 0.0 & 0.1 & 0.0 & 0.0 & 0.0 & 0.0 & 0.0 \\
\hline Other & -0.2 & -0.1 & 0.0 & -0.1 & -0.1 & 0.0 & -0.1 & -0.1 & -0.1 \\
\hline External & 0.9 & 0.0 & 0.0 & 0.0 & -0.3 & 0.4 & 0.2 & 0.3 & 0.6 \\
\hline \multicolumn{10}{|l|}{ Memorandum items: } \\
\hline Primary balance & 2.1 & 1.4 & 0.9 & 0.6 & 0.8 & 1.9 & 0.4 & 0.0 & 0.2 \\
\hline General government balance & 0.3 & -0.2 & $\ldots$ & $\ldots$ & -1.2 & -1.2 & $\ldots$ & $\ldots$ & -1.7 \\
\hline Non-oil primary balance & -2.9 & -4.6 & 0.3 & -3.1 & -3.5 & 0.6 & -3.3 & -5.3 & -6.3 \\
\hline Public debt to GDP & 45.8 & 39.0 & $\ldots$ & 35.5 & 35.0 & $\ldots$ & 34.0 & $\ldots$ & 31.2 \\
\hline
\end{tabular}

Sources: Data provided by the Indonesian authorities; and Fund staff estimates.

1/ From 2004 onward, deposit insurance premia are treated as nontax revenues.

2/ Interest on a due basis (Paris Club moratoria is shown as a financing item).

3/ From 2005 onward, comprises capital spending and social assistance spending.

4/ Includes capitalization of deposit insurance company in 2005. 
Table 7. Indonesia: Selected Vulnerability Indicators, 2005-08

\begin{tabular}{|c|c|c|c|c|c|}
\hline & 2005 & 2006 & 2007 & $20081 /$ & $\begin{array}{r}\text { Latest } \\
\text { observation }\end{array}$ \\
\hline \multicolumn{6}{|l|}{ Key economic and market indicators } \\
\hline Real GDP growth (in percent) & 5.7 & 5.5 & 6.3 & 6.3 & Mar-08 \\
\hline CPI inflation (in percent) & 17.1 & 6.6 & 6.6 & 11.0 & Jun-08 \\
\hline Short-term (ST) interest rate (in percent) & 12.8 & 9.8 & 8.0 & 8.8 & Jul-08 \\
\hline EMBI secondary market spread (bps, end of period) & 269 & 153 & 275 & 381 & Jun-08 \\
\hline Exchange rate $\mathrm{NC} / \mathrm{US} \$$ (end of period) & 9,830 & 8,990 & 9,395 & 9,220 & Jun-08 \\
\hline \multicolumn{6}{|l|}{ External sector } \\
\hline Exchange rate regime & \multicolumn{5}{|c|}{ Managed Float } \\
\hline Current account balance (percent of GDP) & 0.1 & 2.7 & 1.9 & 2.8 & Mar-08 \\
\hline Net FDI inflows (percent of GDP) & 1.8 & 0.9 & 0.7 & 1.5 & Mar-08 \\
\hline Exports (percentage change of US\$ value, GNFS) & 20.7 & 15.1 & 8.6 & 28.2 & Mar-08 \\
\hline Real effective exchange rate (End, period; Jan. $2000=100$ ) & 124.7 & 134.6 & 128.7 & 129.3 & Apr-08 \\
\hline Gross international reserves $(G I R)$ in US $\$$ billion & 34.7 & 42.6 & 56.9 & 59.5 & Jun-08 \\
\hline GIR in percent of ST debt at remaining maturity (RM) & 103.0 & 153.7 & 187.8 & $\ldots$ & Dec-07 \\
\hline Total gross external debt (ED) in percent of GDP & 46.6 & 36.6 & 31.2 & $\ldots$ & Dec-07 \\
\hline Of which: ST external debt (original maturity, in percent of total ED) & 5.9 & 5.3 & 5.5 & $\ldots$ & Dec-07 \\
\hline ED of domestic private sector (in percent of total ED) & 43.8 & 50.0 & 49.1 & $\ldots$ & Dec-07 \\
\hline ED to foreign official sector (in percent of total ED) & 51.5 & 44.5 & 44.2 & $\ldots$ & Dec-07 \\
\hline Total gross external debt in percent of exports of GNFS & 134.0 & 116.0 & 104.5 & $\ldots$ & Dec-07 \\
\hline Gross external financing requirement (in US\$ billion) 2 / & 24.3 & 19.2 & 15.3 & $\ldots$ & Dec-07 \\
\hline \multicolumn{6}{|l|}{ Public Sector (PS) 3/ } \\
\hline Overall balance (percent of GDP) & -0.3 & -1.0 & -1.2 & $\ldots$ & Dec-07 \\
\hline Primary balance (percent of GDP) & 2.1 & 1.4 & 0.8 & $\ldots$ & Dec-07 \\
\hline Gross PS financing requirement (in percent of GDP) 4 / & 3.2 & 3.4 & 3.7 & $\ldots$ & Dec-07 \\
\hline Public sector gross debt (PSGD, in percent of GDP) & 45.8 & 39.0 & 35.0 & $\ldots$ & Dec-07 \\
\hline o/w Exposed to rollover risk (in percent of total PSGD) 5/ & 4.3 & 6.0 & 1.8 & $\ldots$ & Dec-07 \\
\hline Exposed to exchange rate risk (in percent of total PSGD) 6/ & 51.1 & 46.1 & 47.0 & $\ldots$ & Dec-07 \\
\hline Exposed to interest rate risk (in percent of total PSGD) 7/ & 16.6 & 15.7 & 12.4 & $\ldots$ & Dec-07 \\
\hline \multicolumn{6}{|l|}{ Financial Sector (FS) } \\
\hline Capital adequacy ratio (in percent) & 19.3 & 21.3 & 19.3 & 20.5 & Mar-08 \\
\hline NPLs in percent of total loans $8 /$ & 7.6 & 6.1 & 4.1 & 3.8 & Mar-08 \\
\hline Provisions in percent of NPLs & 82.2 & 99.7 & 120.5 & 122.4 & Mar-08 \\
\hline Return on assets (in percent) & 2.6 & 2.6 & 2.8 & 2.7 & Mar-08 \\
\hline Return on equity (in percent) & 32.3 & 33.2 & 28.5 & 31.0 & Dec-07 \\
\hline FX deposits (in percent of total deposits) & 13.1 & 15.5 & 15.6 & 16.5 & Apr-08 \\
\hline FX loans (in percent of total loans) & 16.0 & 18.8 & 20.3 & 19.0 & Apr-08 \\
\hline Government debt held by FS ( percent of total FS assets) & 21.9 & 18.5 & 15.7 & 15.1 & Apr-08 \\
\hline Credit to private sector (percent change) & 19.7 & 12.8 & 25.7 & 29.8 & Apr-08 \\
\hline
\end{tabular}

1/ Staff estimates, projections, or latest available observations as indicated in the last column

2/ Current account deficit plus amortization of external debt.

3/ Public sector covers central government.

4/ Overall balance plus debt amortization.

5/ Short-term debt and maturing medium- and long-term debt, domestic and external, excluding external debt to official creditors.

6/ Debt in foreign currency or linked to the exchange rate, domestic and external, excluding external debt on concessional terms.

7/ Short-term debt and maturing medium- and long-term debt at variable interest rates for domestic debt. Information on external debt is not available.

8/ Loans are gross of any allowance for losses. 
Table 8. Indonesia: Medium-Term Macroeconomic Framework, 2007-13

\begin{tabular}{|c|c|c|c|c|c|c|c|}
\hline & $\underline{2007}$ & 2008 & 2009 & 2010 & 2011 & 2012 & 2013 \\
\hline & Act. & \multicolumn{6}{|c|}{ Proj. } \\
\hline Real GDP (percent change) & 6.3 & 6.1 & 6.3 & 6.5 & 6.7 & 6.7 & 6.7 \\
\hline Domestic demand & 4.2 & 6.8 & 6.7 & 6.8 & 7.2 & 7.5 & 8.0 \\
\hline \multicolumn{8}{|l|}{ Of which: } \\
\hline Private consumption & 5.0 & 5.1 & 5.1 & 5.5 & 6.0 & 6.3 & 6.7 \\
\hline Gross fixed investment & 9.2 & 11.0 & 10.4 & 10.1 & 10.4 & 10.7 & 11.1 \\
\hline Change in stocks $1 /$ & -1.5 & 0.1 & 0.0 & 0.1 & 0.1 & 0.0 & 0.1 \\
\hline Net exports $1 /$ & 0.4 & 0.3 & 0.4 & 0.4 & 0.3 & 0.0 & -0.5 \\
\hline Statistical discrepancy $1 /$ & 2.2 & -0.2 & 0.0 & 0.0 & 0.0 & 0.0 & 0.0 \\
\hline \multicolumn{8}{|l|}{ Saving and investment (in percent of GDP) } \\
\hline Gross investment $1 /$ & 22.5 & 23.6 & 24.5 & 25.4 & 26.3 & 27.3 & 28.5 \\
\hline Gross national saving & 25.0 & 25.6 & 25.3 & 25.7 & 25.9 & 26.6 & 27.3 \\
\hline Foreign saving (external current account balance) & -2.5 & -2.0 & -0.8 & -0.3 & 0.4 & 0.6 & 1.2 \\
\hline \multicolumn{8}{|l|}{ Prices (12-month percent change) } \\
\hline Consumer prices (end period) & 6.6 & 12.0 & 7.5 & 6.5 & 5.6 & 5.1 & 5.0 \\
\hline Consumer prices (period average) & 6.4 & 10.6 & 8.7 & 7.0 & 6.0 & 5.3 & 5.0 \\
\hline \multicolumn{8}{|l|}{ Public finances (in percent of GDP) } \\
\hline Central government revenue & 17.8 & 20.4 & 20.1 & 19.9 & 19.3 & 18.8 & 18.3 \\
\hline Central government expenditure & 19.1 & 22.4 & 22.2 & 21.7 & 21.2 & 20.8 & 20.3 \\
\hline Central government balance & -1.2 & -1.9 & -2.1 & -1.8 & -1.9 & -1.9 & -1.9 \\
\hline Primary balance & 0.8 & 0.2 & -0.2 & 0.0 & -0.1 & -0.1 & -0.1 \\
\hline Central government debt & 35.0 & 31.2 & 29.4 & 27.9 & 26.8 & 26.0 & 25.2 \\
\hline \multicolumn{8}{|l|}{ Balance of Payments (in billions of US\$) } \\
\hline Oil and gas (net) & 6.0 & 2.7 & -0.1 & 0.0 & -3.2 & -5.9 & -10.0 \\
\hline Non-oil exports (f.o.b) & 93.1 & 109.9 & 113.4 & 117.5 & 123.8 & 132.2 & 141.1 \\
\hline Non-oil imports (f.o.b) & -66.1 & -78.7 & -83.6 & -88.6 & -94.9 & -102.2 & -110.0 \\
\hline Current account balance & 11.0 & 9.8 & 4.2 & 1.7 & -2.4 & -4.8 & -9.9 \\
\hline Direct foreign investment & 1.8 & 2.7 & 3.4 & 4.0 & 4.5 & 5.2 & 5.7 \\
\hline Overall balance & 13.2 & 6.2 & 6.4 & 7.9 & 7.7 & 9.4 & 9.2 \\
\hline \multicolumn{8}{|l|}{ Gross reserves } \\
\hline In billions of U.S. dollars (end period) & 56.9 & 63.4 & 69.7 & 77.8 & 84.6 & 92.2 & 99.4 \\
\hline In months of imports & 5.1 & 5.1 & 5.3 & 5.6 & 5.7 & 5.8 & 6.0 \\
\hline As a percent of short-term debt $2 /$ & 159.9 & 213.4 & 246.9 & 282.1 & 334.3 & 360.9 & 213.5 \\
\hline \multicolumn{8}{|l|}{ Total external debt } \\
\hline In billions of U.S. dollars & 137.4 & 140.8 & 143.4 & 145.4 & 146.4 & 146.0 & 144.4 \\
\hline In percent of GDP & 31.7 & 28.3 & 25.5 & 23.6 & 21.6 & 19.6 & 17.6 \\
\hline \multicolumn{8}{|l|}{ Memorandum items: } \\
\hline Oil production (000bcpd) & 899 & 927 & 955 & 1,031 & 1,021 & 1,031 & 1,010 \\
\hline Indonesian oil price (US\$/bbl) & 70.7 & 116.1 & 124.6 & 123.1 & 123.1 & 123.1 & 123.4 \\
\hline Nominal GDP (in billions of U.S. dollars) & 433 & 500 & 565 & 620 & 681 & 748 & 822 \\
\hline
\end{tabular}

Sources: Data provided by the Indonesian authorities; and Fund staff estimates.

$1 /$ Includes changes in stocks. Computed on real basis.

2/ Short-term debt on a remaining maturity basis. 
Table 9. Indonesia: Progress on Structural Reforms

\begin{tabular}{|c|c|c|}
\hline Area & Measure & Status \\
\hline \multirow[t]{5}{*}{$\begin{array}{l}\text { Investment } \\
\text { climate }\end{array}$} & $\begin{array}{l}\text { The Law of the Republic of Indonesia No. } 252007 \\
\text { concerning Investment; } \\
\text { Equal treatment of foreign and domestic investors, } \\
\text { streamlining procedures for starting business. }\end{array}$ & $\begin{array}{l}\text { Approved by Parliament in March } \\
2007 . \\
\text { Enacted on April } 26^{\text {th }} 2007 \text {. }\end{array}$ \\
\hline & $\begin{array}{l}\text { The Law of the Republic of Indonesia No. } 402007 \\
\text { concerning Limited Liability Company; } \\
\text { To increase national economy and to provide a } \\
\text { strong foundation for the business world in facing } \\
\text { the development of world economy and progress } \\
\text { in science and technology in the coming } \\
\text { globalization era. }\end{array}$ & Enacted on August $16^{\text {th }} 2007$. \\
\hline & $\begin{array}{l}\text { Shipping Bill; } \\
\text { To allow foreign and domestic private entities to } \\
\text { operate ports in Indonesia without having to } \\
\text { partner or seek the aid of state port operators. }\end{array}$ & $\begin{array}{l}\text { Approved by Parliament on } \\
\text { April } 8^{\text {th }} 2008 \text {. }\end{array}$ \\
\hline & $\begin{array}{l}\text { New Mining Bill; } \\
\text { Would replace The Law of the Republic of } \\
\text { Indonesia No. } 111967 \text { concerning Mining. The } \\
\text { new bill would clarify authority and responsibility } \\
\text { of the central government, province, and } \\
\text { municipal to grant license, regulate, and obligation } \\
\text { to add value. }\end{array}$ & $\begin{array}{l}\text { The draft is being discussed since } \\
\text { 2007, and still ongoing with no } \\
\text { apparent due date. }\end{array}$ \\
\hline & Simplify customs procedures & Ongoing. \\
\hline \multirow[t]{3}{*}{$\begin{array}{l}\text { Financial } \\
\text { sector }\end{array}$} & $\begin{array}{l}\text { Sharia Banking Bill; } \\
\text { To serve as the legal basis for an alternative } \\
\text { market instrument such as sharia bonds. }\end{array}$ & $\begin{array}{l}\text { Approved by Parliament on } \\
\text { April } 8^{\text {th }} 2008 .\end{array}$ \\
\hline & $\begin{array}{l}\text { Financial System Safety Net Bill; } \\
\text { To serve as a foundation for a mechanism and } \\
\text { division of labor in time of crisis or shocks in the } \\
\text { financial market. }\end{array}$ & $\begin{array}{l}\text { The draft is being discussed since } \\
2007 \text {, and expected to be } \\
\text { approved before the end of } 2008 \text {. }\end{array}$ \\
\hline & Development of securities markets. & $\begin{array}{l}\text { Decree on Primary Dealer System } \\
\text { signed on September } 6^{\text {th }} 2007 . \\
\text { Treasury bills introduced in July } \\
2007 .\end{array}$ \\
\hline $\begin{array}{l}\text { Fiscal } \\
\text { reforms }\end{array}$ & $\begin{array}{l}\text { The Law of The RI No. } 282007 \text { Concerning Tax; } \\
\text { NAs for new Income Tax Bill and Value Added } \\
\text { Tax Bill or amendment is still ongoing. }\end{array}$ & $\begin{array}{l}\text { Enacted on July } 17^{\text {th }} 2007 . \\
\text { Ongoing. }\end{array}$ \\
\hline \multirow[t]{2}{*}{$\begin{array}{l}\text { Fiscal } \\
\text { reforms }\end{array}$} & $\begin{array}{l}\text { Treasury reforms. } \\
\text { Strengthened regulations on cash management. } \\
\text { Establishment of treasury single account (TSA). }\end{array}$ & $\begin{array}{l}\text { Introduced in July } 2007 \text {. } \\
\text { Some key issues still outstanding, } \\
\text { including remuneration of deposits } \\
\text { at } \mathrm{BI} \text { and placement of } \\
\text { government deposits. }\end{array}$ \\
\hline & $\begin{array}{l}\text { Civil service reforms. } \\
\text { MoF ministerial decree 30/KMK.01/ } 2007 \text { aimed at } \\
\text { improving business processes, human resource } \\
\text { management, and introducing performance- } \\
\text { related pay in the MoF. }\end{array}$ & Decree passed on January 2007. \\
\hline
\end{tabular}




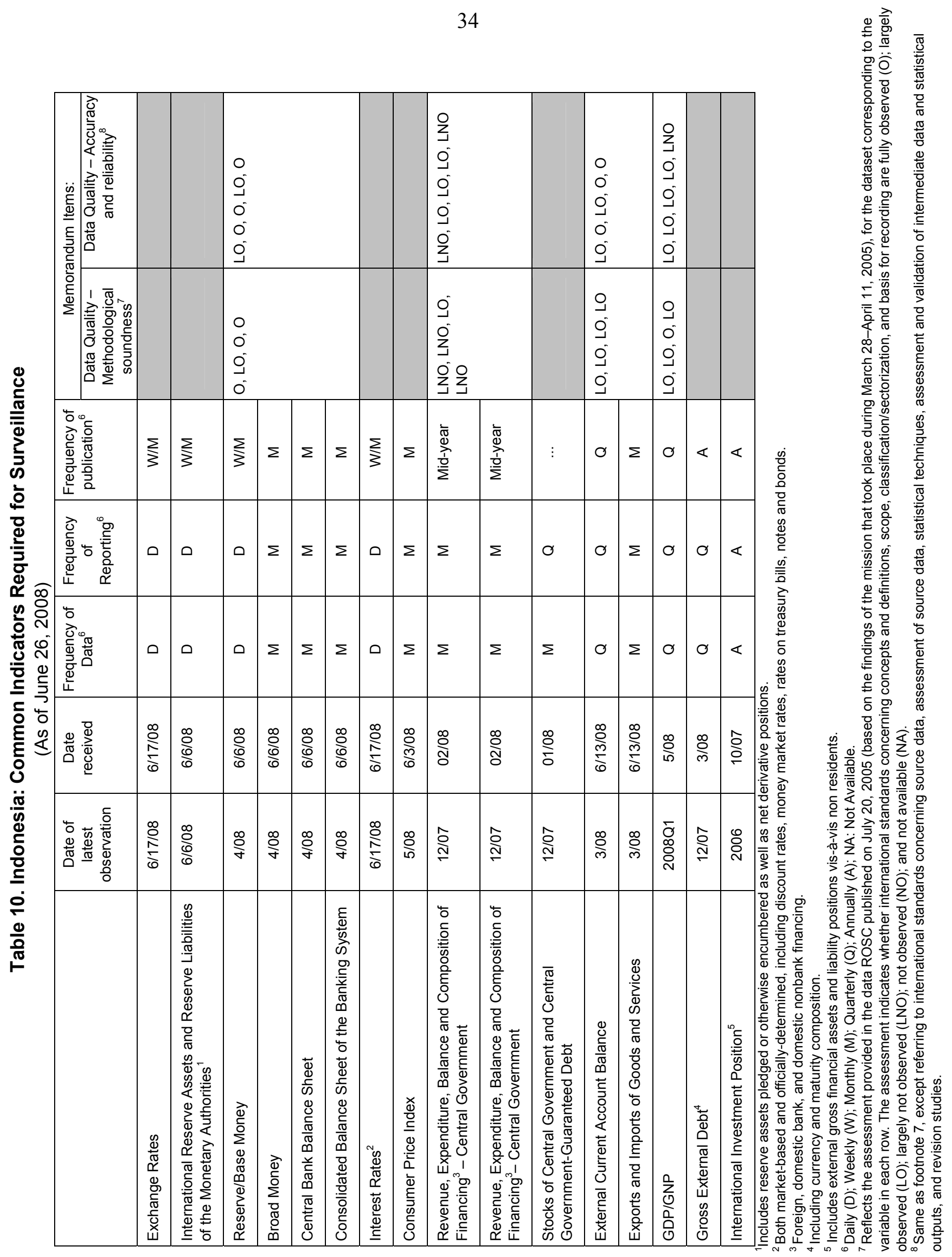




\section{APPENDIX I. INDONESIA: MEDIUM-TERM OUTLOOK UNDER AN ADVERSE MACRO Scenario ANd Public and EXTernal Debt Sustainability}

This annex compares the medium-term outlook under the baseline with an adverse macro scenario based on a more severe global slowdown, a sharp decline in commodity prices, and capital outflows, triggered by tightening global liquidity and increasing risk aversion. It also analyzes the impact of several exogenous shocks on the sustainability of public sector debt and external debt.

\section{ADVERSE SCENARIO}

\section{Sharper global growth slowdown, accompanied by a fall in commodity prices, higher risk aversion, and capital outflows.}

Macro shocks: Global growth is assumed to slow further, by 1 percentage point relative to the WEO baseline for 2009, while major export commodity prices, including oil, fall by 20 percent relative to the baseline (resulting in an oil price of $\$ 100$ per barrel). The anticipated adverse impact is assumed to trigger increased risk aversion and cause a market sell-off in Indonesian equity and bond markets, as well as the rupiah.

Policy response: BI is assumed to increase the policy rate by around $200 \mathrm{bps}$ relative to the baseline to stem the capital outflow, stabilize the exchange rate, and limit the impact on inflation. In addition, BI is also assumed to intervene in the foreign exchange market to cushion the effects of capital outflows. Fiscal policy aims to contain the deficit through some cuts in capital expenditures.

Projections: Lower global growth and commodity prices lead to a contraction in exports. Combined with the deceleration of domestic demand as a result of higher interest rates and negative market sentiment, the result is GDP growth of about 5 percent (about 1 percent below the baseline). With the exchange rate depreciating by around 15 percent, inflation picks up to 8.5 percent (versus 7.5 percent in the baseline). Bond yields would rise by $200 \mathrm{bps}$ in line with policy interest rates and equity prices fall by 30 percent, reflecting higher interest rates, lower commodity prices, and a weaker economy. The current account surplus narrows (by 0.3 percentage points) due to lower export receipts, which, together with capital outflows, leads to slowdown in reserve accumulation. The fiscal position would deteriorate due to declining revenue and higher interest cost, despite the offsetting effect of lower energy subsidies and some cuts in capital expenditure, resulting in a deterioration of the fiscal deficit by around 0.2 percentage points of GDP. 
Figure 1. Alternative Scenarios (In percent)
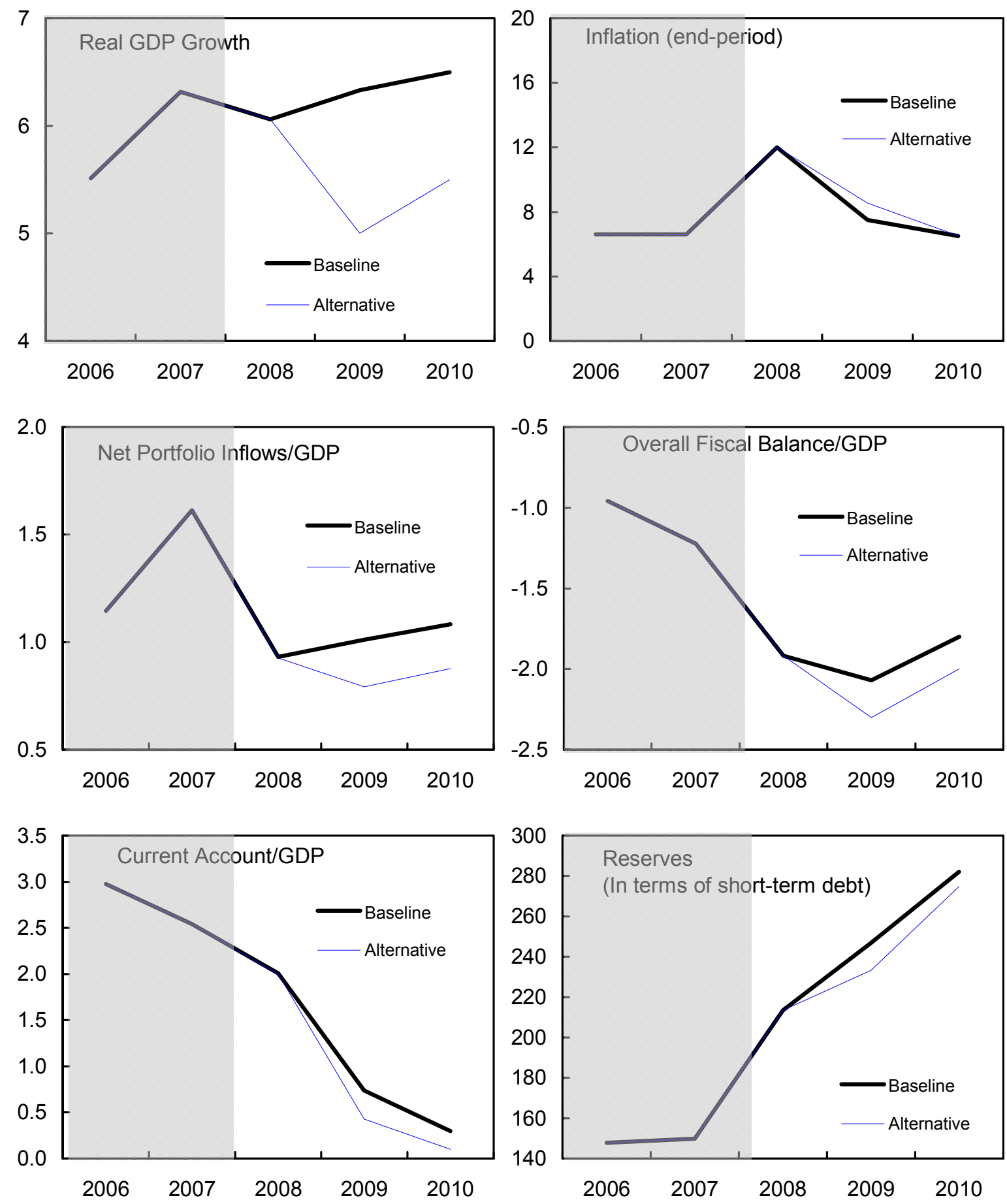

Sources: CEIC Data Co.Ltd.; and Fund staff estimates. 


\section{Debt SuStainability Analysis Under the BaSeline Scenario}

\section{A. Public Debt}

1. The public sector debt ratio has declined steadily from 58 percent of GDP at end-2003 to an estimated 35 percent at end-2007 (Figure 2). This reflects the government's fiscal consolidation policy, declining interest rates, and high real GDP growth rates. The share of debt held by foreign creditors (mostly multilateral institutions) has declined to less than 50 percent. This trend is likely to continue as the authorities increasingly tap the domestic bond market.

2. Under the baseline scenario, public sector debt is expected to decline to around 25 percent of GDP by 2013. In terms of government revenues, public sector debt will decline from 196 percent to 138 percent over the 2007-13 period. These results are based on the key assumptions underlying the baseline projections for 2008-13, specifically that:

(1) real GDP growth averages 6.5 percent;

(2) the primary surplus averages 0.1 percent of GDP; and (3) average nominal interest rates on public debt increase slightly to 7.9 percent by

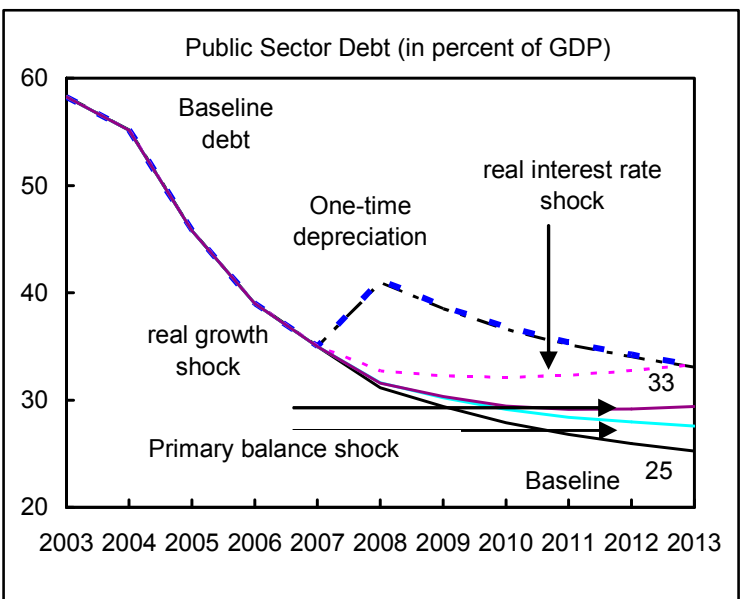
the end of the period.

3. The standard sensitivity analysis shows that the trajectory of the debt ratio is most sensitive to changes in interest rates, exchange rates or contingent liabilities (Figure 2). Increasing average real interest rates by half of the historical standard deviation, a one-time 30 percent real depreciation of the exchange rate, or a 10 percent increase in contingent liabilities eventually lead to a 8 percentage points of GDP increase in the debt ratio by 2013. Other macroeconomic shocks have a more limited impact.

\section{B. External Debt}

4. Indonesia's external debt has also declined steadily since the crisis, from over 150 percent of GDP in 1998 to around 32 percent in 2007 (Figure 3). External debt as a percentage of exports has also declined, from 288 percent to 105 percent, over the same period.

5. External debt dynamics are sustainable under the baseline scenario, with the debt to GDP ratio declining to around 18 percent by 2013. The main factors driving these favorable dynamics are: (1) real GDP growth projected to increase to 6-7 percent over the medium term; (2) a projected positive growth- interest rate differential; and (3) an expected 
increase in non-debt-creating capital inflows. The favorable trend in external debt may be reversed if these positive developments do not occur.

\section{External debt sustainability is} most vulnerable to shocks to the exchange rate. A one-time 30 percent real exchange rate depreciation would raise the debt ratio by around 16 percentage points in 2009, with the impact declining to

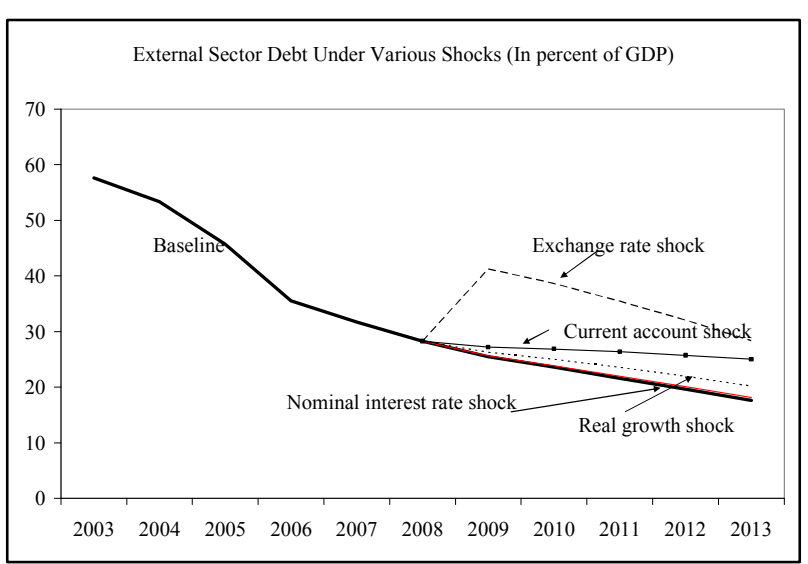
around 11 percentage points over the baseline by 2013 . 


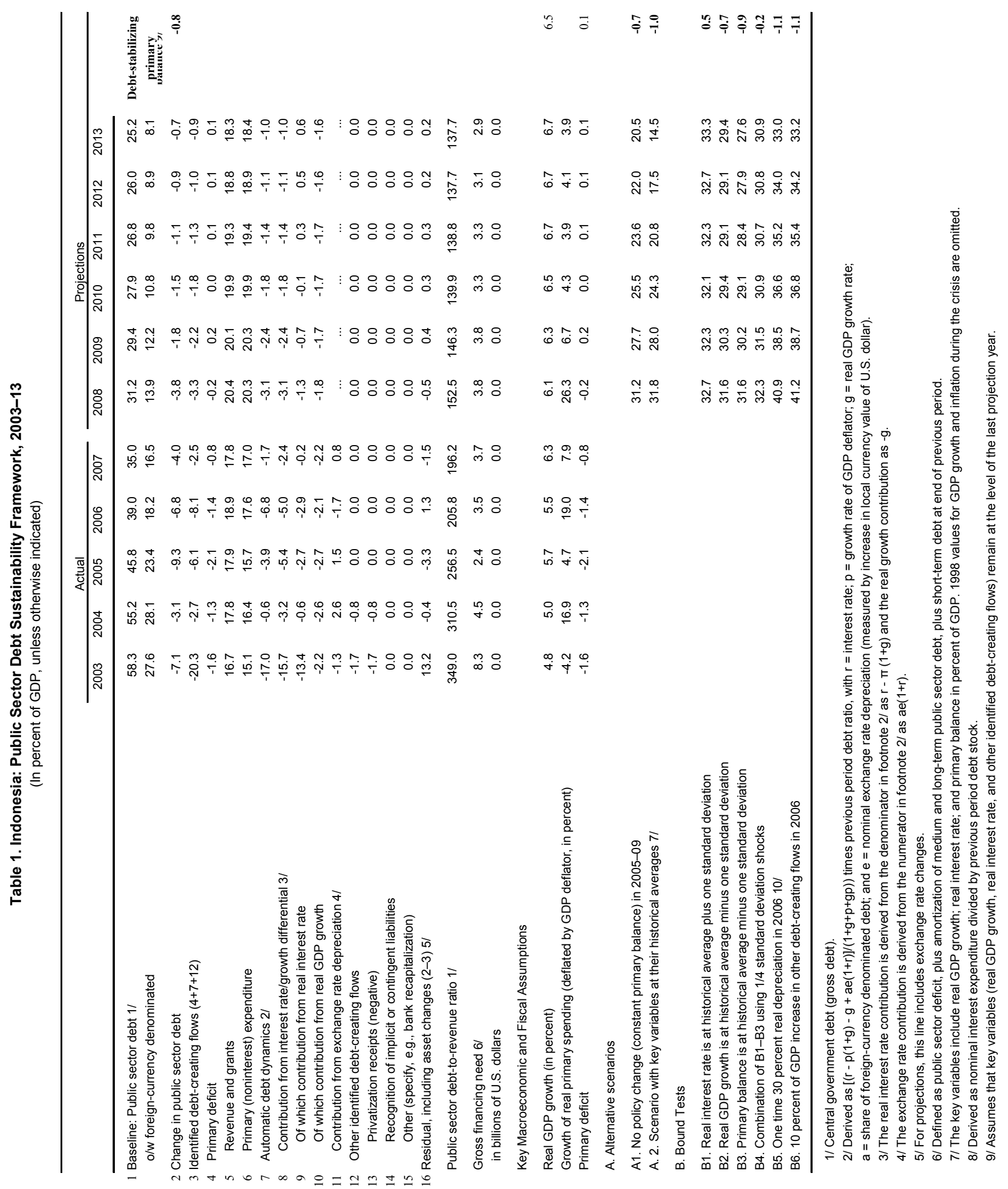


Figure 2. Indonesia: Public Debt Sustainability: Bound Tests 1/ (Public debt in percent of GDP)
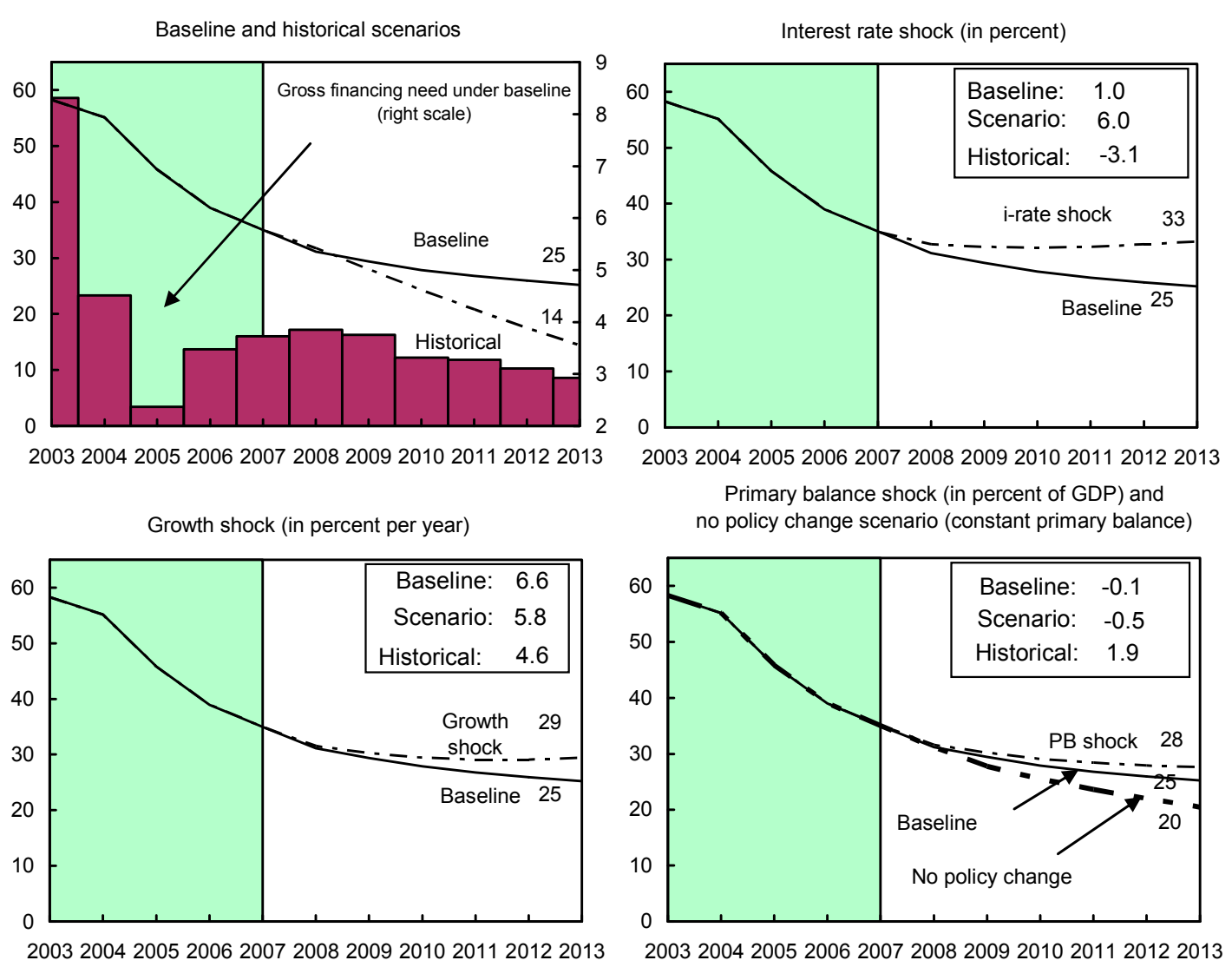

Combined shock 2/

Real depreciation and contingent liabilities shocks $3 /$
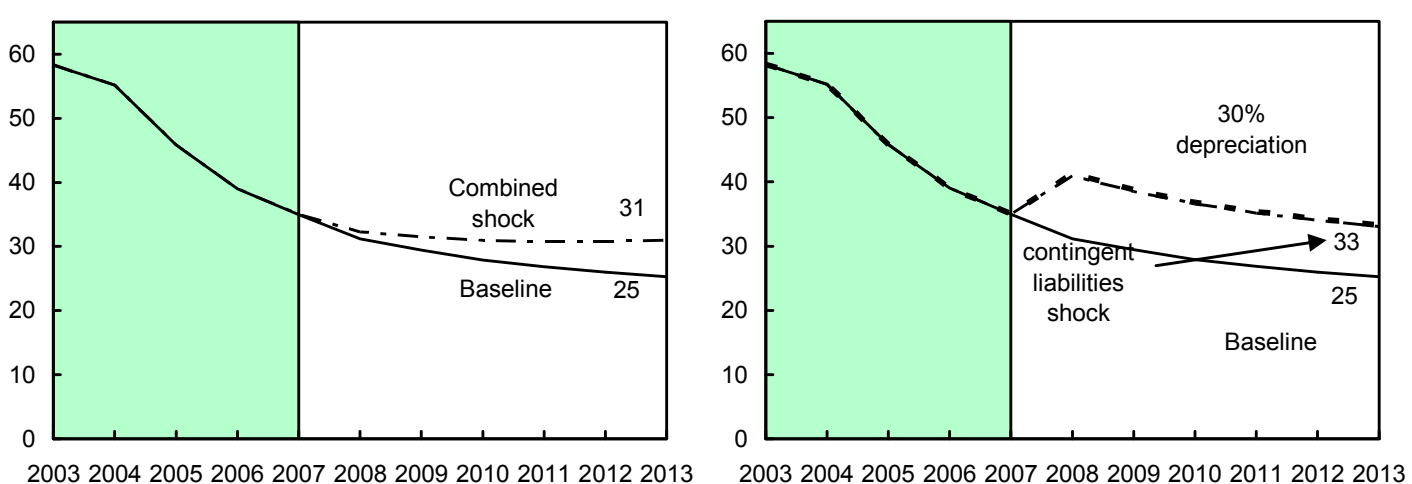

Sources: International Monetary Fund; Country desk data; and staff estimates.

1/ Shaded areas represent actual data. Individual shocks are permanent one-half standard deviation shocks. Figures in the boxes represent average projections for the respective variables in the baseline and scenario being presented. Ten-year historical average for the variable is also shown.

2/ Permanent 1/4 standard deviation shocks applied to real interest rate, growth rate, and primary balance. $3 /$ One-time real depreciation of 30 percent and 10 percent of GDP shock to contingent liabilities occur in 2008 , with real depreciation defined as nominal depreciation (measured by percentage fall in dollar value of local currency) minus domestic inflation (based on GDP deflator).

4/ 1998 values for GDP growth and inflation during the crisis are omitted. 


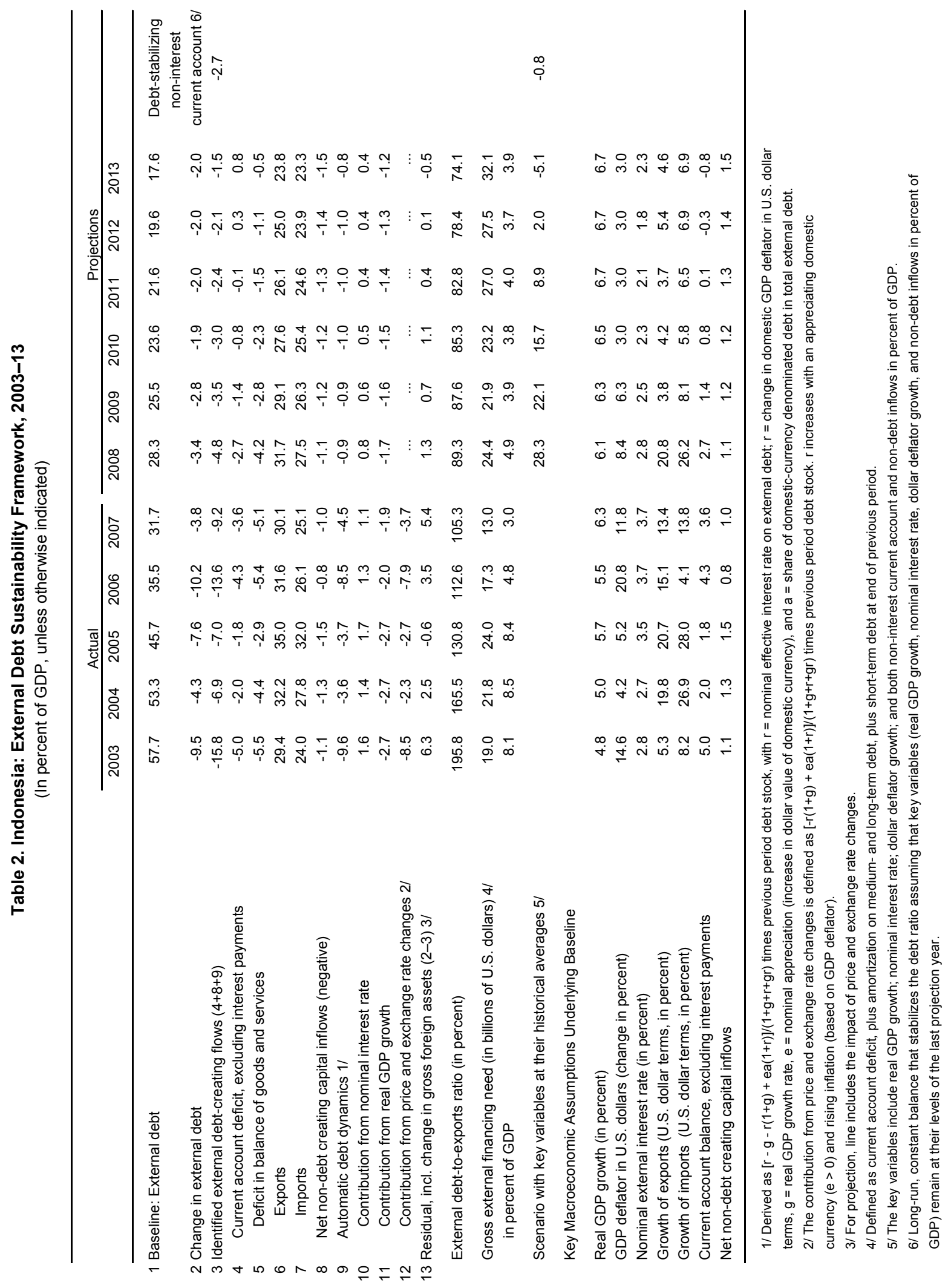


Figure 3. Indonesia: External Debt Sustainability: Bound Tests 1/ (External debt in percent of GDP)
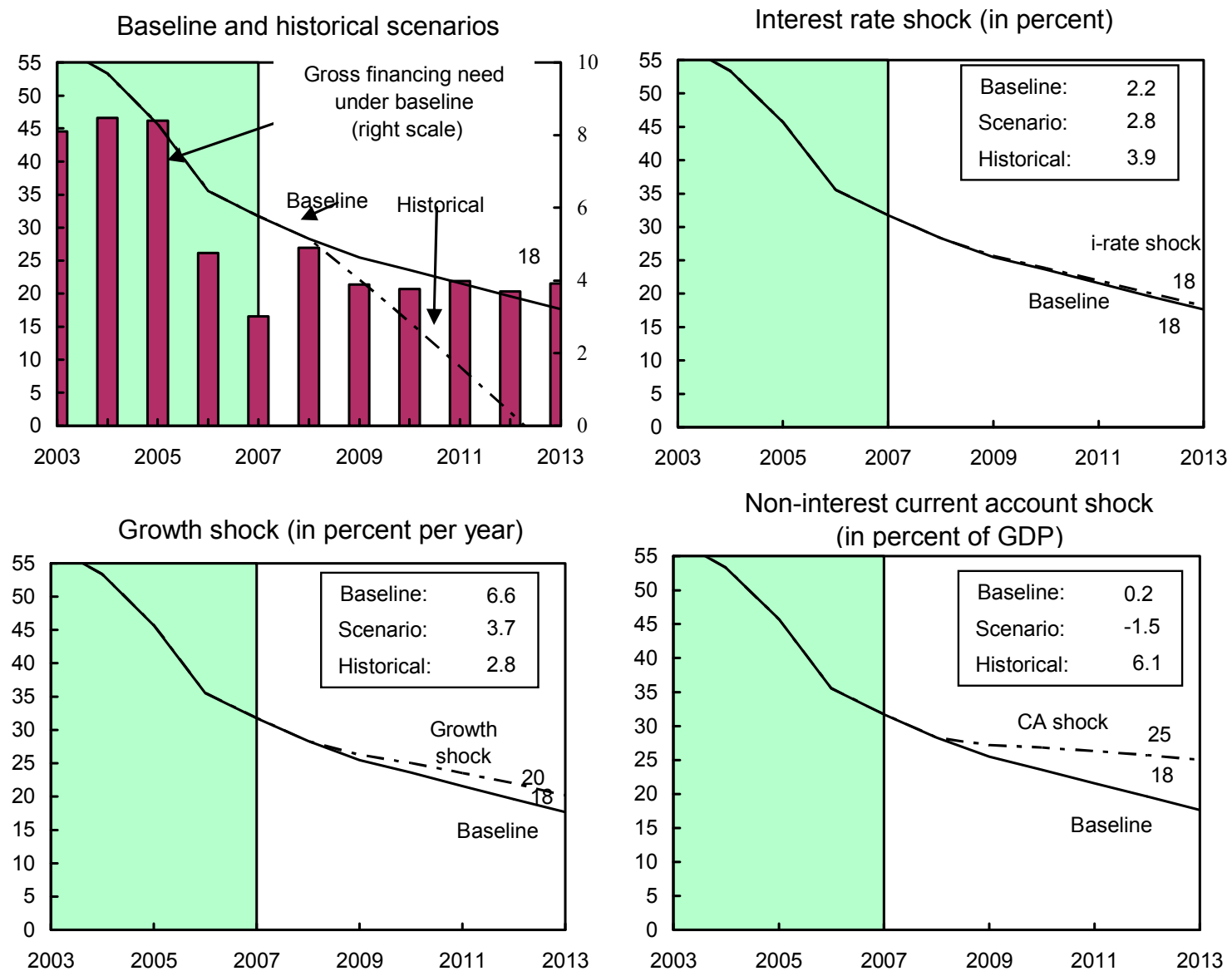

Combined shock 2/

Real depreciation shock 3/
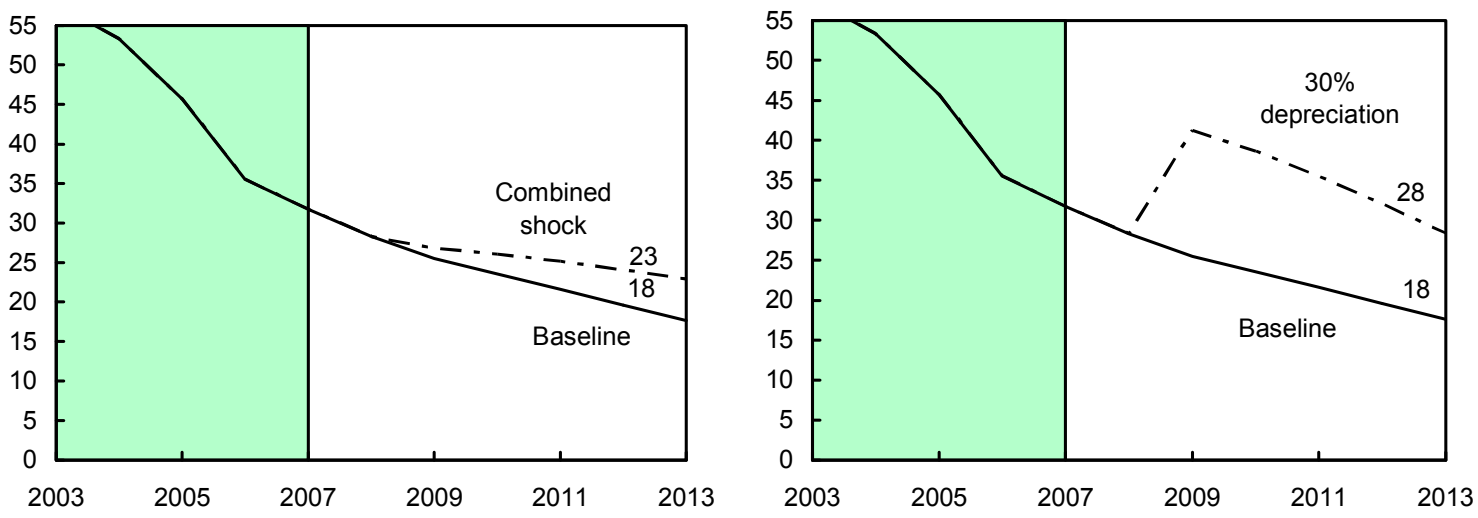

Sources: International Monetary Fund; Country desk data; and staff estimates.

1/ Shaded areas represent actual data. Individual shocks are permanent one-half standard deviation shocks. Figures in the boxes represent average projections for the respective variables in the baseline and scenario being presented. Ten-year historical average for the variable is also shown.

2/ Permanent 1/4 standard deviation shocks applied to real interest rate, growth rate, and current account balance.

3/ One-time real depreciation of 30 percent occurs in 2009. 


\section{INTERNATIONAL MONETARY FUND \\ INDONESIA}

\section{Staff Report for the 2008 Article IV Consultation-Informational Annex}

Prepared by the Asia and Pacific Department

July 11, 2008

Contents

Page

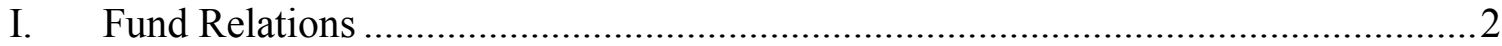

II. Relations with the World Bank Group................................................................ 3

III. Relations with the Asian Development Bank ....................................................6

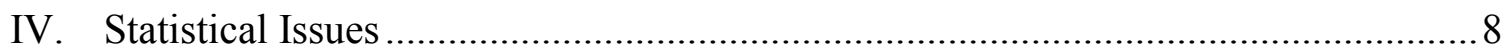




\section{ANNEX I. INDONESIA: FUND RELATIONS}

(As of May 31, 2008)

I. Membership Status: Joined February 21, 1967; Article VIII

\section{General Resources Account \\ Quota}

Fund holdings of currency

Reserve position in Fund

III. SDR Department

Net cumulative allocation

Holdings $\begin{array}{rr}\text { SDR Millions } & \text { Percent of Quota } \\ 2,079.30 & 100.00 \\ 1933.80 & 93.00 \\ 145.50 & 7.00\end{array}$

$\underline{\text { SDR Millions }}$

238.96

23.81

Percent of

$\underline{\text { Allocation }}$

100.00

9.97

\begin{tabular}{|c|c|c|c|c|}
\hline IV. & \multicolumn{2}{|c|}{ Outstanding Purchases and Loans } & None & \\
\hline V. & Financial Arrangements & & & \\
\hline Type & Approval Date & Expiration Date & $\frac{\underline{\text { Amount }}}{\frac{\text { Approved }}{\text { (SDR Millions) }}}$ & $\begin{array}{l}\text { Amount Drawn } \\
\text { (SDR Millions) } \\
\end{array}$ \\
\hline EFF & Feb. 04, 2000 & Dec. 31,2003 & $3,638.00$ & $3,638.00$ \\
\hline EFF & Aug. 25, 1998 & Feb. 04, 2000 & $5,383.10$ & $3,797.70$ \\
\hline Stand-by & Nov. 05, 1997 & Aug. 25, 1998 & $8,338.24$ & $3,669.12$ \\
\hline
\end{tabular}

VI. Projected Payments to Fund (expectations basis) (SDR Millions; based on existing use of resources and present holdings of SDRs):

Forthcoming

Principal

Charges/Interest

Total

\begin{tabular}{lllll}
$\underline{6008}$ & $\underline{2009}$ & $\underline{2010}$ & $\underline{2011}$ & $\underline{2012}$ \\
\hline$\underline{3.19}$ & $\underline{6.4}$ & $\underline{6.41}$ & $\underline{6.41}$ & $\underline{6.41}$ \\
$\underline{3.19}$ & $\underline{6.4}$ & $\underline{6.41}$ & $\underline{6.41}$ & $\underline{6.41}$
\end{tabular}

\section{Exchange Arrangements}

The rupiah has floated since August 14, 1997. The market exchange rate was Rp 9,303 per U.S. dollar on June 17, 2008. Indonesia has accepted the obligations of Article VIII, Sections 2, 3, and 4, and maintains an exchange system free of restrictions on payments and transfers for current international transactions.

\section{Article IV Consultation}

The last Article IV consultation report (Country Report No. 07/272) was discussed by the Executive Board on July 18, 2007. 


\section{ANNEX II. INDONESIA: WORLD BANK RELATIONS}

(As of June 20, 2008)

\section{Indonesia Country Assistance Strategy (CAS)}

The World Bank's CAS for Indonesia was extended by one year to FY08 (from July 2007 to June 2008) to coincide with Indonesia's scheduled graduation from IDA funding. The Bank Group's strategy remains strongly aligned to that of the government. The CAS addresses the two fundamental problems impeding rapid poverty reduction: (i) a weak investment climate and (ii) the lack of quality service delivery to the poor. Both of these challenges, in turn, arise from the same fundamental cause-weak governance. In addition, the significant expansion of the Bank program and quick redeployment of resources to postdisaster efforts (notably in Aceh and Yogyakarta/Central Java) in the context of perennial natural disasters call for a greater emphasis on natural disaster management. Lastly, given the good track record of reform, continued financing need, solid macroeconomic indicators, and improved creditworthiness, the CAS supports the request by government to recalibrate assistance toward more program lending, namely the on-going Development Policy Lending (DPL) series and the Infrastructure DPL.

A new Country Partnership Strategy (CPS), which reflects Indonesia's transition from IDA to middle income country status, is currently under preparation and is expected to go to the Board in second half of 2008. The CPS will focus on improving Indonesia's institutions, both at the central and sub-national level, through six core areas of engagement: private sector development, infrastructure, poverty reduction, education, climate change and natural resource management, and disaster mitigation and recovery.

\section{World Bank Engagement: Selected Highlights}

Improving the Climate for High Quality Investment: The DPL program, coupled with targeted projects, a large AAA program, and IFC interventions are supporting policy and institutional reforms for higher growth. Reforms supported by DPLs have helped consolidate macroeconomic stability; enhanced competitiveness of the financial sector; streamlined procedures for business start-up, trade, and customs; improved tax administration; and promoted SMEs. A robust dialogue on infrastructure provision is addressing a key constraint to growth. Key issues being addressed through TA include regulatory reforms, new legislation, risk management, and PPP. A strategy to mobilize long-term private financing through NBFIs has been developed and a project establishing infrastructure and guarantee funds is currently under preparation. The IFC has complemented Bank work in several of these areas, including local financing of infrastructure, business licensing, and SME development. Bank Group activities have focused on the rural investment climate, with a set of projects to help modernize services to farmers and fishing communities and to address 
related issues on water management, agricultural services, agribusiness, land titling, irrigation, and coral reef protection.

Making Service Delivery Responsive to the Poor: Bank efforts have strongly supported improvements in quality and equitable access to education, water and sanitation (WSS), and health services. Activities have focused on strengthening capacity and systems, and changing the way services are managed and delivered top-to-bottom to improve results. Financial support in education targets the full range of issues from early childhood development (ECD) to tertiary education. The Bank has supported an education sector review and the development of a comprehensive national medium-term strategy (RENSTRA) covering all levels of education, formal and non-formal. A series of Provincial Health Projects (PHPs) were designed to help clarify the roles of different levels of government. Interventions have also aimed at district health administrations' capacities and making service planning and delivery more participatory and accountable. The focus is on areas where indicators lag behind neighboring countries: maternal and child health, and nutrition. CDD approaches in WSS and the GEG program seek to inculcate a more sanitary and healthier environment. The Bank is currently involved in the Government's National Program of Community Empowerment (PNPM) and a Conditional Cash Transfer Program. Several of these service delivery efforts are also supported by a service delivery policy pillar within the DPL program.

Addressing the Core Issue of Governance: The World Bank recognizes governance as the most critical cross-sectoral issue and, hence, has positioned it at the core of the Bank's work program. The DPL program and particularly the Government Financial Management and Revenue Administration Program (GFMRAP) are designed to improve public administration, particularly in the area of public financial management. Along with well targeted interventions, such as Public Expenditure Reviews, trust funded programs supporting corruption prevention and civil service reform, the relatively large CDD portfolio are resulting in progress toward strengthening accountability, functional streamlining and modernization of processes both at the national, subnational, and community levels. Via the multi-donor Decentralization Support Facility (DSF), the Bank works with other donors to improved decentralization and donor effectiveness.

Program for the Recovery of Aceh and Nias: The Bank is deeply engaged in the recovery of Aceh and Nias, with a focus on post-tsunami reconstruction, institution building, analytical support and monitoring of progress. The Bank has mobilized an Aceh reconstruction program substantial in scope and objectives. The Bank has played a vital role in putting in place key elements for the management of the reconstruction effort and coordinating the response of the international community. Immediately after the tsunami, in partnership with the Netherlands, the Bank established a multi-donor office in Banda Aceh, and made the facilities available to all donors working in Aceh. The community based 
housing approach deployed by the Bank in Aceh under the MDF housing project, has been indicated by the Government of Indonesia as the model for the massive housing reconstruction program in Yogyakarta and Central Java, following the May 2006 earthquake. At the government's request, the Bank has established the Multi-donor Java reconstruction Fund (JRF), primarily supporting housing reconstruction with total value of pledge US\$79 million. Given Indonesia's geographic location and vulnerability to natural disasters, Disaster Management has become an important component of the Bank's country strategy.

New Lending Operations: As of June 2008, the Bank's active portfolio comprised 25 projects with a total net commitment of $\$ 2.7$ billion and an undisbursed balance of $\$ 1.7$ billion. In FY07, in addition to the development policy loan, 7 projects were delivered for a total lending volume of $\$ 1.2$ billion. For FY08, $\$ 1.3$ billion was approved, including the Fourth DPL (\$600 million), an Infrastructure DPL (\$200 million), the BERMUTU education project (\$86 million), the Urban and Rural Community Empowerment projects (\$409 million) and a GEF Geothermal project (\$4 million). For FY09, two development policy loans and projects in urban water, dams, roads, community empowerment, education, youth employment, public finance management, and infrastructure financing are expected to be delivered.

\section{Analytic and Advisory Activities (AAA)}

There is sustained Bank engagement in policy dialogue with GOI, on the direction and substance of its economic, structural, and institutional reform agenda. The AAA program has been organized around five "breakthrough" themes: (1) investment climate, (2) reducing poverty, (3) improving decentralized service delivery, (4) improving governance, and (5) progress and constraints in the recovery of Aceh and Nias. The "flagship reports" in

related areas, the stand-alone policy notes and think pieces, and day to day informal dialogue between Bank staff and government counterparts, are providing support to GOI in making informed policy choices and in defining the shape of supporting Bank programs.

For questions relating to this annex, contact Bill Wallace, at (+62-21) 5299-3000 or Preeti Ahuja at 202 473-1657 


\title{
ANNEX III. Indonesia: RELATIONS WITH THE ASIAN DEVELOPMENT BANK ${ }^{1}$ (As of July 4, 2008)
}

\begin{abstract}
Asian Development Bank (ADB) cumulative loans to Indonesia exceeded \$22.5 billion at end-December 2007. In 2007, the ADB approved a total of $\$ 950$ million or 7.2 percent of the total loans approved by the institution for the year. The assistance provided financing mainly for three programs to accelerate progress towards achieving the Millennium Development Goals in education and health and contribute to the poverty reduction agenda, promote resilience of the financial sector, and to improve the investment climate, public financial management, and public service delivery in Indonesia. It also covered a project loan supporting government efforts to reduce and prevent malnutrition in Indonesia based on strengthening community-based services, community empowerment, and social mobilization.
\end{abstract}

In 2006 the ADB Board endorsed the Indonesia Country Strategy and Program (CSP) 20062009. The CSP aims to help the government achieve higher levels of pro-poor sustainable growth and to enhance social development, with a key thematic focus on governance and capacity development in all operations. Five areas of engagement were derived to address the main constraints to development: improved infrastructure and infrastructure services, deepened financial sector, improved decentralization, accelerated MDG achievement, and strengthened environment and natural resources management. Since then annual public sector lending and non-lending programs has been agreed with the government selectively focusing on these areas of engagement.

Between 1967 and 2007, ADB also provided 491 Technical Assistance grants to Indonesia amounting to \$253.66 million. The TA grants were financed from ADB's Technical Assistance Special Fund, the Japan Special Fund, and other sources. In 2007, eight TA grants amounting to $\$ 6.2$ million was approved, and represented 2.5 percent of total TA grants approved by ADB during the year.

Table 1. Loan Approvals and Disbursements to Indonesia 1/

\begin{tabular}{lrrrrrr}
\multicolumn{8}{c}{ (In millions of U.S. dollars) } \\
\hline Loan approvals & 2002 & 2003 & 2004 & 2005 & 2006 & 2007 \\
\hline Loan disbursement & 767.2 & 261.6 & 225.0 & $1,145.69$ & 784.8 & $1,187.1$ \\
& $1,000.5$ & 442.9 & 593.5 & $1,014.99$ & $1,025.88$ & $1,136.3$ \\
Sources: Asian Development Bank, 2007 Annual Report, and ADB staff. \\
1. Include loans to private sector without government guarantee but excludes equity investments.
\end{tabular}

\footnotetext{
${ }^{1}$ Prepared by ADB staff.
} 
Table 2. Cumulative Lending to Indonesia (As of December 31, 2007)

\begin{tabular}{lcrr}
\hline \multicolumn{1}{c}{ Sector } & $\begin{array}{c}\text { Loans } \\
\text { (no.) }\end{array}$ & $\begin{array}{c}\text { Amount } \\
\text { (\$ million) }\end{array}$ & $\mathbf{\%}^{\mathrm{a}}$ \\
\hline Agriculture and Natural Resources & 92 & $3,864.29$ & 17.13 \\
Education & 31 & $2,142.35$ & 9.50 \\
Energy & 32 & $3,856.05$ & 17.09 \\
Finance & 16 & $3,046.10$ & 13.50 \\
Health, Nutrition and Social Protection & 13 & $1,068.30$ & 4.74 \\
Industry and Trade & 14 & 695.70 & 3.08 \\
Law, Economic Management and & 12 & $1,959.22$ & 8.69 \\
Public Policy & & & \\
Multisector & 38 & $2,836.83$ & 12.58 \\
Transport and Communication & 33 & $2,713.86$ & 12.03 \\
Water Supply, Sanitation and & 10 & 375.60 & 1.67 \\
Waste Management & & & \\
& & & \\
Total & $\mathbf{2 9 1}$ & $\mathbf{2 2 , 5 5 8 . 3 0}$ & $\mathbf{1 0 0 . 0 0}$ \\
\hline
\end{tabular}

${ }^{\text {a }}$ Total may not add up because of rounding. Sources: Asian Development Bank, Indonesia Fact Sheet 2008, and ADB staff. 


\section{ANNEX IV. INDONESIA: STATISTICAL ISSUES ${ }^{2}$}

1. Indonesia's macroeconomic statistics and statistical base are broadly adequate to conduct effective surveillance. Indonesia has been a subscriber to the Special Data Dissemination Standard (SDDS) since September 1996, observing most of the SDDS requirements. Exceptions include the currency composition in the reserve template in the first quarter of 2007, general government data for 2005, and the timeliness in the production index data where short delays have occurred.

\section{Real Sector}

2. The annual national accounts have 2000 as the base year. Quarterly GDP data are published in a timely manner for both expenditure and production sides. The estimates are based on a limited set of indirect indicators of uncertain quality. Some sectors are influenced strongly by seasonality, and seasonally adjusted data are prepared but not published. In addition, no survey of nonfinancial services is prepared. An economic census of businesses is undertaken every 10 years, without updates in the intervening period. The household budget survey does not cover higher income households. There are inconsistencies with the Bank of Indonesia (BI) in imports and exports; and, with the Ministry of Finance (MoF) regarding local government figures. The five-yearly input-output tables remove statistical discrepancies, but there are large discrepancies in the intervening years. The Fund has recommended: (i) development of a system to continuously update the census of businesses; (ii) introduction of comprehensive annual establishment surveys for nonfinancial services industries; (iii) publication of annual GDP estimates, including a time series of at least 20 years; (iv) development of a set of annual supply and use tables (SUTS) starting from 2000; (v) expedited conversion to the 1993 System of National Accounts; and (vi) enhancing the convergence exercise on trade data with BI.

3. Labor market data, including wages and employment, are available, albeit reported with some delay, through the annual labor market survey (Sakernas) published by the Bureau of Statistics. Data on minimum and maximum wages for the formal sector are also available. Quarterly data are available on industrial wages, with some delay.

\footnotetext{
2 The section is based on a Detailed Assessment of Indonesia's observance of the IMF's Data Quality Assessment Framework, prepared by STA in March 2005.
} 


\section{Public Finance}

4. Available government finance data suffer from a number of weaknesses, in terms of classification, coverage, and timeliness. Data on budgetary central government were available until recently with a one-month lag, but subnational (provincial and local) government data are available only with a lag of two years, and the quality of this data is variable. Problems in budget and accounting systems have been compounded by the recent decentralization initiatives, which have shifted substantial resources to the subnational governments. Substantial efforts are in train, and significant progress has been made to overcome these problems, ranging from the planned adoption of advanced accounting and statistical standards, to the introduction of best practice budget management processes, and the development of computerized financial management information systems.

5. Against this background, the MoF and the Ministry of Home Affairs are committed to keeping the requirements of fiscal statistics at the forefront of ongoing fiscal reforms, so as to make better statistical monitoring one of the goals of the current efforts. Reflecting the close link between this major reform process and its impact on data reporting, it should be noted that the one-month lag on central government reporting lengthened significantly, but only temporarily, in the course of 2007 as a new revenue reporting system was put in place. This should reverse itself as the reform is fully implemented. The coverage and timeliness of public debt statistics is generally adequate; however, only limited information on contingent liabilities is available. The new expenditure classification introduced in the 2005 budget, is generally consistent with the Government Finance Statistics Manual 2001 (GFSM 2001) on functional codes and classification, although the data are compiled on a cash basis.

6. The authorities have committed to adopting GFSM 2001 standards. To this end, the Fund staff has recommended in the short term: (i) establishment of a register of all extrabudgetary units to improve the coverage of central government activity; and (ii) inclusion of the economic codes consistent with the GFSM 2001 in the chart of accounts to ensure that general government units report in a statistically meaningful way all transactions and balances over which they exert control. Over the medium-term, priority should be given to (i) seizing the opportunity offered by the two new subnational fiscal reform efforts to simultaneously establish the underlying reporting arrangements to obtain timely preliminary data for local government statistics; and (ii) to develop GFSM 2001 operating statements, statements of sources and uses of cash, and partial balance sheets, all of which should be published on the MoF websites. ${ }^{3}$

\footnotetext{
${ }^{3}$ Local Government Finance and Governance Reform (LGFGR) project.
} 


\section{Monetary Accounts}

7. Good quality monetary statistics are compiled by the BI on a timely basis. With STA assistance, BI has developed an integrated database from which alternative presentations of monetary statistics can be drawn to meet the needs of BI and the Fund. Further work, however, is needed to expand the coverage of depository corporations to include mutual funds (REKSA DANA), which report data to BAPEPAM — an agency that supervises some of the nonbank financial institutions. To this end, $\mathrm{BI}$ is currently developing institutional data-sharing arrangements that would enable it to access the register of - and data onmutual funds.

8. To strengthen monetary statistics, STA missions have recommended: (i) collection of source data on mutual funds in a format that meets statistical requirements; (ii) expansion of the coverage of the monetary statistics to include mutual funds; and (iii) harmonization of the reported interbank positions between the $\mathrm{BI}$ and commercial banks.

\section{Balance of Payments}

9. Trade data are affected by some shortcomings. While customs sources utilized by the BI are considered generally reliable, coverage of merchandise trade flows is insufficient. Also, when the online reporting system for exports and imports was introduced in 2004, the historical series were reconstructed only as far back as 2003. As a result, prior to 2003 balance of payments statistics are not entirely consistent with the national accounts estimates. Data on services suffer from outdated surveys and weak methodologies. The BI adjusts the customs data to cover exports and imports of Batam and other bonded zones. Data on services suffer from outdated surveys and weak methodology. Adjustments are also made to data on compensation of employees and workers' remittances to cover professional workers, legal workers not reported to the Ministry of Manpower, and illegal workers.

10. For the capital and financial account, the methodological basis for the compilation of FDI data needs substantial improvement. Inflows are currently calculated based on loan disbursements to companies that have foreign equity using a fixed ratio to estimate equity inflows. Surveys conducted by BI to collect FDI data have a low response rate and the coverage of the directory of enterprises should be improved. Other areas that need improvement include the recording of trade credits and the asset data for portfolio investment and other investment transactions. The magnitude of the errors and omissions item has been significant and appears to be related to the methodology used, for instance, for unrecorded assets in the financial account. Financial transactions data have not been reconciled with changes in the International Investment Position (IIP).

11. The BI has proposed a range of measures to address these weaknesses. On traderelated data, a working group has been established to reconcile differences between BI and 
customs data. The BI is planning to collect and publish data on goods imported for processing, goods procured in ports by carriers, and transactions with the oil and gas sector. On the financial account, the BI is planning to collect and publish data on direct investment abroad, portfolio investment assets, other investment assets, and trade credits, to help address the shortcomings in the recording of private financial flows.

\section{International Investment Position}

12. An annual IIP is compiled, but the underlying data are weak in several areas, notably for FDI. External debt statistics have improved considerably with the introduction of an External Debt Information System (EDIS) in 2002. The system records external debt of government and over 800 other entities that report to the BI on a monthly basis. The system generates data for public sector external debt and debt service, as well as those for private banks, that are considered reliable. However, improvements are still needed with respect to components of private corporate sector data, particularly in distinguishing between scheduled and actual debt service, in estimating the accumulation/reduction of private sector payments arrears, and in estimating rescheduling and debt reductions received by the private sector from external creditors. 


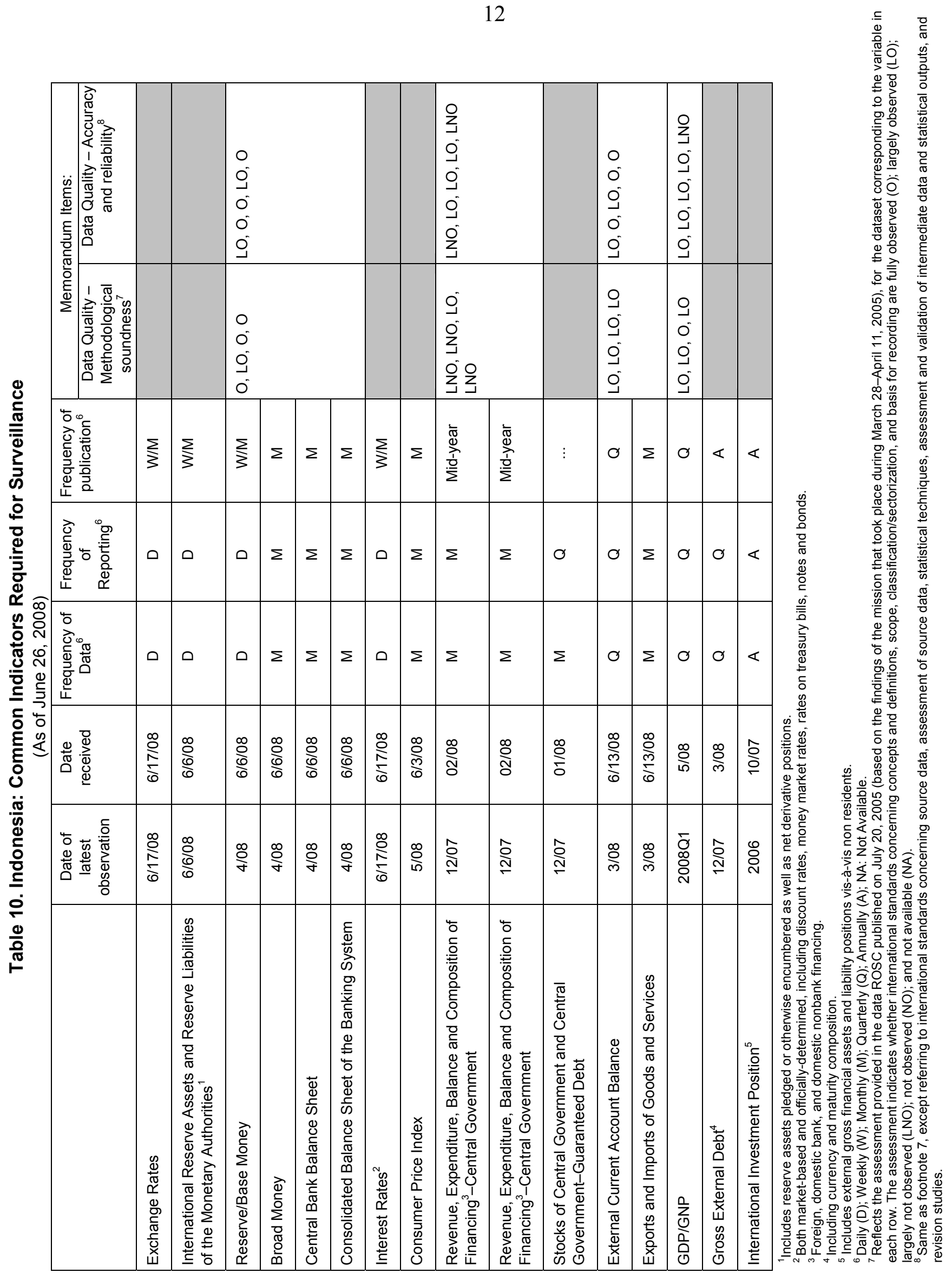




\section{Statement by the IMF Staff Representative on Indonesia August 1, 2008}

1. This statement provides an update on recent economic developments based on information received after the staff report was issued. The new information does not alter the thrust of the staff appraisal.

\section{High-frequency indicators suggest that economic activity remains firm despite} the rise in domestic fuel prices in May. Motor vehicle and motorcycle sales continued to rise rapidly in June (by 38 percent (y/y) and 46 percent, respectively). Cement consumption and investment imports remain strong as well, while exports have been growing by nearly 30 percent $(\mathrm{y} / \mathrm{y})$ in nominal terms. GDP growth in the second quarter is, therefore, expected to have remained above 6 percent.

3. Indonesian financial markets have strengthened in the last few weeks. Pressures in the government bond market have eased, reflecting market expectations that inflation may have peaked, a relatively positive budget outlook, and the favorable outcome of the sovereign issue in June. Ten-year government bond yields have declined by 175 basis points from the highs in mid-June, while the last bond auctions have attracted larger than expected demand. Despite renewed strains in global financial markets, foreign ownership of SBI (central bank notes) and SUN (government bonds) has increased by nearly $\$ 5$ billion since mid-June, contributing to an appreciation of the rupiah of around 2 percent against the dollar.

\section{The government presented an updated projection of the 2008 budget and} announced some key features of its draft 2009 budget proposal. The 2008 fiscal deficit is expected to be 1.9 percent of GDP, slightly below the revised budget, on account of stronger revenues and some cuts in expenditure. Nevertheless, energy subsidies are projected to reach 5.7 percent of GDP, compared to 4.2 percent of GDP in previous projections. The draft 2009 budget proposal, which will be submitted to parliament in August, envisages a lower fiscal deficit of 1.5 percent of GDP, as tax revenues are expected to improve by 0.4 percentage points of GDP. The proposal aims at curtailing subsidized fuel consumption through the kerosene-LPG conversion program, while increasing infrastructure and development expenditure. The draft budget proposes a new revenue sharing mechanism with the regions and incorporates contingencies to protect the budget in case oil prices reach $\$ 160$ p.b. 


\section{INTERNATIONAL MONETARY FUND}

Public Information Notice (PIN) No. 08/106

FOR IMMEDIATE RELEASE

August 12, 2008
International Monetary Fund

$70019^{\text {th }}$ Street, NW

Washington, D. C. 20431 USA

\section{IMF Executive Board Concludes 2008 Article IV Consultation with Indonesia}

On August 1, 2008, the Executive Board of the International Monetary Fund (IMF) concluded the 2008 Article IV consultation with Indonesia. ${ }^{1}$

\section{Background}

Since the conclusion of the last Article IV consultation in mid-2007, Indonesia's growth performance has remained strong despite the deteriorating global environment. Growth of 6.3 percent in 2007, the highest growth rate in a decade, was driven by domestic demand, both robust private consumption and a rebound in investment that included a strong rise in foreign direct investment. While exports performed strongly, supported by continuing demand for Indonesia's commodities, the recovery of imports in the second half of the year reduced the contribution of net exports to growth. The growth momentum was maintained in the first quarter of 2008. As a result, poverty and unemployment have declined significantly, though they remain high at 15.4 percent and 8.5 percent, respectively.

Nevertheless, new challenges have emanated from rising commodity prices. Government bond yields have risen by about 250 basis points since end-February as investor sentiment deteriorated due to surging fuel subsidies and inflation concerns. Domestic fuel prices were subsequently increased by about 29 percent. Headline inflation has accelerated to 11.0 percent at end-June, while core inflation reached 8.7 percent at end-May (latest available data), well above Bank Indonesia's (BI) 4-6

\footnotetext{
${ }^{1}$ Under Article IV of the IMF's Articles of Agreement, the IMF holds bilateral discussions with members, usually every year. A staff team visits the country, collects economic and financial information, and discusses with officials the country's economic developments and policies. On return to headquarters, the staff prepares a report, which forms the basis for discussion by the Executive Board. At the conclusion of the discussion, the Managing Director, as Chairman of the Board, summarizes the views of Executive Directors, and this summary is transmitted to the country's authorities.
} 
percent target range for end-2008. After lowering interest rates to 8 percent and then holding them unchanged since late 2007 , BI hiked rates three times since May by a total of 75 basis points in response to rising inflation. Nevertheless, the real policy interest rate calculated on the basis of core inflation has been declining over the year and is currently around zero. Meanwhile, uncertainty remains as international oil and food prices have continued to rise, global growth is expected to slow in 2008.

The external position remains generally strong. Staff estimates that the real exchange rate is moderately undervalued. Nevertheless, the nominal effective exchange rate (NEER) depreciated further (by 10 percent) in 2007, which likely contributed to inflationary pressures, while Indonesia accumulated US\$14 billion of reserves. However, in $2008 \mathrm{BI}$ has slowed the accumulation of reserves and the NEER has remained stable. While the current account recorded a surplus of 2.5 percent of GDP in 2007 supported by gains in the price of major commodity exports, there have been some episodes of capital outflows and external financing conditions have tightened somewhat as a result of the global financial market turmoil.

Fiscal performance has been strong despite rising fuel subsidies. Energy subsidies rose to 3 percent of GDP in 2007 (almost a third of total current spending). Nevertheless, the fiscal deficit was contained to 1.2 percent of GDP, well below the government's target. Revenue performance was buoyant, with an across the board surge in non-oil and gas revenue being a testament to both the underlying strength of the economy and payoff from ongoing reforms in tax administration. Budget execution has also improved noticeably, in particular in the area of development expenditure.

Indonesia's financial sector has displayed resilience in the face of the global credit market turmoil. Several factors have limited the transmission of global financial shocks, including (i) reduced external vulnerabilities, (ii) low exposure to structured credit and derivative products, (iii) ample domestic liquidity, and (iv) relatively low reliance on external financing. Financial soundness indicators have improved, with banking sector profitability increasing, and gross non-performing loans (NPLs) declining to 4 percent amid strong private credit growth. The stock market index remains about 6 percent above the level at end-June 2007. Nevertheless, volatility has increased, and since endFebruary, Emerging Markets Bond Index (EMBI) and Credit Default Swaps (CDS) spreads have widened more than in other emerging market countries and the government bond market came under stress in March, reflecting largely investors' concerns about inflation and fuel subsidies.

\section{Executive Board Assessment}

Executive Directors welcomed the resilience of the Indonesian economy to the global slowdown and financial market turmoil, underpinned by strong macroeconomic fundamentals and the highly liquid and well-capitalized banking system. Robust domestic demand and buoyant exports supported by high commodity prices have contributed to this commendable performance, and are expected to continue to sustain the growth momentum. Downside risks are associated with a less favorable external environment, a possible slump in commodity prices, and remaining vulnerability to spikes in global risk aversion and contagion from other emerging markets. 
Directors saw as a key immediate challenge the need to rein in the inflationary pressures stemming from the large increases in food and fuel prices and strong domestic demand. They welcomed the recent increases in interest rates, and considered that further monetary policy tightening will be needed to put inflation back on a firmly declining path. Directors encouraged the authorities to continue to strengthen the inflation targeting framework, through effective communication, publication of inflation forecasts, and a strong commitment to the medium-term targets. They agreed that the shift of the operational target to the interbank overnight rate has been managed well and will enhance the effectiveness of monetary policy.

Directors considered Indonesia's flexible exchange rate policy appropriate. Noting the staff's assessment that the real effective exchange rate may be somewhat undervalued, Directors welcomed the new policy of increased reselling of oil receipts, which should help strengthen the currency and support monetary policy in dampening inflationary pressures. They underscored that such a policy should be pursued with care to avoid creating perceptions of specific exchange rate targets. At the same time, efforts should continue on the structural front to strengthen external competitiveness. While reserve levels are broadly adequate, some additional accumulation over the medium term could further reduce vulnerabilities.

Directors welcomed Indonesia's strong fiscal performance. They considered the fiscal stance appropriate and consistent with a substantial reduction of the public debt burden. Directors commended the authorities for addressing the challenge of energy subsidies through the recent fuel price increase, accompanied by cash transfers to the poor. Going forward, Directors encouraged the authorities to move toward an automatic fuel price adjustment mechanism, which would be the preferred solution to ensure fiscal space for capital and social expenditures and guard against emerging concerns about the sustainability of subsidies. In the interim, further ad-hoc adjustments would help reduce the cost of fuel subsidies. Directors welcomed the progress made in public finance reforms, and looked forward to the completion of the pending reforms of the tax system and tax administration. To further enhance fiscal transparency, the authorities were encouraged to consider participating in the Extractive Industries Transparency Initiative.

Directors observed that Indonesia's banking system remains relatively resilient to macroeconomic shocks and exchange rate risks. They agreed that the rapid credit growth calls for close monitoring and strict adherence to prudential regulations in line with international standards. Directors supported the planned gradual transition to Basel II, and welcomed the review of the financial safety net, with a view to ensuring timely responses in case of a crisis. They looked forward to Indonesia's early participation in the Financial Sector Assessment Program (FSAP).

Directors welcomed progress toward implementing structural reforms over the past year. Further efforts will nevertheless be needed to achieve higher sustainable GDP growth, aimed particularly at improving the business climate and accelerating infrastructure development. In that regard, Directors viewed the recently announced policy packages as a welcome signal of the authorities' intention to press ahead with the structural reform agenda. 
Public Information Notices (PINs) form part of the IMF's efforts to promote transparency of the IMF's views and analysis of economic developments and policies. With the consent of the country (or countries) concerned, PINs are issued after Executive Board discussions of Article IV consultations with member countries, of its surveillance of developments at the regional level, of post-program monitoring, and of ex post assessments of member countries with longer-term program engagements. PINs are also issued after Executive Board discussions of general policy matters, unless otherwise decided by the Executive Board in a particular case. 
Indonesia: Selected Economic Indicators, 2005-09

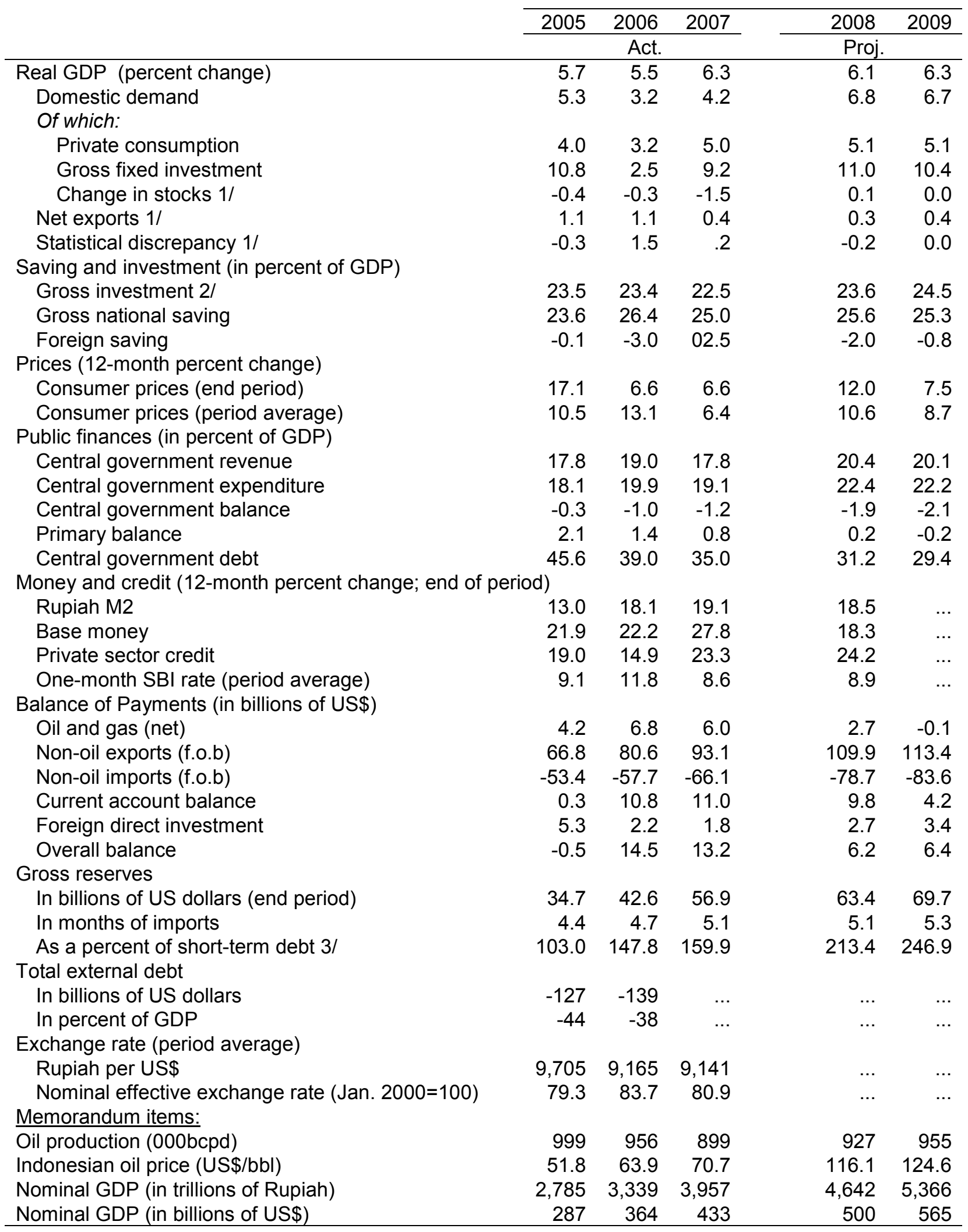

Sources: Data provided by the Indonesian authorities; and IMF staff estimates.

1/ Contribution to GDP growth (percentage points).

$2 /$ Includes changes in stocks. Computed on real basis.

$3 /$ Short-term debt on a remaining maturity basis. 


\section{Statement by Perry Warjiyo, Executive Director for Indonesia and Juda Agung, Advisor to Executive Director August 1, 2008}

1. On behalf of the Indonesian authorities, we would like to express our appreciation to the staff for their constructive policy dialogue during the 2007 Article IV Consultation and for their balanced report and relevant Selected Issues paper. The Indonesian authorities broadly agree with general thrusts of the staff' assessment of the Indonesia's economic performance and their policy suggestions to maintain macroeconomic stability and sustain the growth momentum in the face of current deteriorating global environment.

\section{The Indonesian economy and financial system have weathered remarkably} well against the on-going high oil and food prices and current global economic slowdown. The authorities have taken bold measures to adjust their economic policy mix to maintain macroeconomic stability and growth momentum. To secure fiscal sustainability and at the same time allow the needed fiscal space, domestic fuel prices were raised to cut subsidies, accompanied by well-targeted social transfers and reinforcing current expenditure restraints to improve efficiency in the public sectors. The central bank has pre-emptively raised its policy interest rate to curb inflation expectations and the second-round impacts of domestic fuel price increase. At the same time, the structural reforms are moving forward to improve the quality of economic growth through improvements in the investment climate, acceleration of infrastructure development, and strengthening financial system stability.

\section{Recent Updates and Outlook}

3. In 2007, the Indonesian economy has recorded the highest performances for the first time since the Asian crisis. The economy grew at a record high of 6.3 percent, while inflation remained within the target range of 5-7 percent. The growth has been broad based, with a substantial acceleration of investment and buoyant consumer demand, particularly driven by reform progress, improved business perception and purchasing power. The government budget deficit was well contained at 1.3 percent of GDP, while the debtGDP ratio continued to decline rapidly, falling to around 30 percent by the end of 2007. Balance of payments continued to record significant surpluses, contributing to international reserves of US\$ 59.5 billion at end-June 2008, equivalent to 5.1 months of imports and external public debt services.

4. Going forward, given the slowdown in the global economy and continued high commodity prices, the economy would moderate slightly in 2008 and 2009 . Our authorities are, however, confident that the economy will continue to hold up the global slowdown reasonably well, with growth projected to around 6 percent for 2008 and return to 6.3 percent in 2009. High commodity prices would remain a key driver of Indonesian exports, while in the domestic side, the rapid credit expansion and the better investment climate will continue to boost the domestic consumption and investment. Indonesia's balance 
of payments is expected to remain strong, giving positive impacts on exchange rate stability. Like staff, the authorities see containing inflation and managing the fiscal impact of high oil prices continue to be the immediate key policy challenges. However, our authorities believe that inflationary pressures will ease and return into the range of $6 \frac{1}{2}-71 / 2$ percent in 2009 following the monetary tightening supported by the on-going fiscal and structural measures.

\section{Fiscal Policies and Reforms}

\section{The $\mathbf{2 0 0 8}$ revised budget centers on safeguarding fiscal position from} escalating fuel subsidies while continue to creating fiscal space for growth. On the revenue side, the fiscal reforms that have been progressing well over the past years have yielded the needed increases in tax and non-tax revenues as well as dividend from SOE's. Nonetheless, measures on spending are also needed, and indeed our authorities have taken bold measures to reprioritize expenditures and improve their efficiency. Expenditures of government agencies and line ministries were cut by as much as 10 percent while at the same the authorities introduced an energy saving program, improved efficiency in Pertamina and PLN, and retained the policy for food subsidies for the poor. Additionally, steps were taken to accelerate the transfer from highly subsidized kerosene to less subsidized LPG.

6. A bolder step was taken by raising the domestic fuel prices in May 2008. While this move is essential to maintain the credibility of the budget, it is also aimed at creating fiscal space for priority spending on infrastructure and social programs. To cushion the impact of higher fuel prices on the most vulnerable groups, the authorities re-implemented the targeted cash transfer program. Moving forward, while our authorities share the staff's suggestion on the need to gradually eliminate the fuel subsidies in the long-term, they see that it is politically not feasible in the short run given next year's election. Meanwhile, in transition towards market prices, the government is considering introducing a mechanism for limiting consumption of subsidized fuels. Along with further steps to improve expenditure efficiency and revenue enhancements for the remainder of this year, the government is confident that the deficit for fiscal year 2008 can be contained at 1.9 percent of GDP, lower than that approved in the revised budget. Looking ahead, the 2009 budget will remain prudent with a deficit expected at around 1.5-2.0 percent of GDP, which is consistent with the declining path of public debt and growth target of 6.0-6.4 percent.

\section{Reforms for strengthening public financial management have continued}

progressing well. As well documented in the Selected Issues Paper, the reforms to improve the efficiency and effectiveness of fiscal institutions have been successfully completed. Further reforms in the fiscal area are continuously underway. They include comprehensive tax administration reforms through establishing small taxpayer offices, modernizing tax and custom administrations with the use of IT, and bureaucracy reform in tax offices and customs. A national single windows system in the customs was introduced to expedite the processing of both import and export documents. This is also complemented by a provision 
of fast track facilities for importers and exporters with a good track record in regulatory compliance.

Progress towards implementation of a treasury single account is also encouraging. On the fiscal transparency, the government started to publish a fiscal risk statement in the 2008 budget document, making Indonesia one of the pioneers in fiscal risks analysis among emerging market countries.

\section{Monetary and Exchange Rate Policies}

8. Bank Indonesia (BI) has shifted to tightening monetary policy mode to preemptively contain the inflationary pressures. In fact, BI has raised its policy rate by 75 bps from 8 to $83 / 4$ percent since May 2008. The major sources of inflation in 2008 are the impacts of the increases in domestic fuel and food prices. However, the central bank is also monitoring closely inflationary pressures stemming from domestic demand as well as from inflation expectations following the second round effects of fuel price increase. BI will stay the course and stand ready to adjust its policy interest rate consistent with the aim to bring down the inflation towards a designated range of target in 2009. BI shares the staff' view not to revise the inflation target for 2008, but intends to make a public statement on the missed target.

9. To strengthen the monetary policy effectiveness, BI has steadily improved its operating framework with an expanded range of monetary instruments and strengthened communication and transparency. Since June 2008, the central bank changed its monetary operational target from 1 month Bank Indonesia Certificate (SBI) rate to the overnight inter-bank rate. Available monetary instruments have been supplemented by the launching of fine tune operations (FTOs), narrowing implicit standing facility, and progressive improvements in liquidity projections and management. Indeed, with the new operating framework, the interbank interest rate has increased by 400 bps since December 2007, further reinforcing the tightening monetary policy mode that BI has adopted. To strengthen the credibility of monetary policy, BI has revamped its monetary policy communications and transparency with the use of press releases and publication of monthly, quarterly and annual economic reports, while also holding seminars and discussion programs.

10. With regard to exchange rate policy, our authorities remain committed to a flexible exchange rate regime. In this regard, exchange rate movements are mainly determined through market mechanisms. As such, the current level of exchange rate is considered appropriate and relatively consistent with the fundamentals. Interventions in the foreign exchange market are confined to smoothing abrupt movements in the exchange rate without targeting any specific exchange rate level. In this context, the recent recycling official foreign exchange receipts is aimed to limit the exchange rate volatility, particularly when the supply of foreign exchange in the market is limited. Our authorities have taken note the staff's suggestion to adopt an automatic mechanism for recycling foreign exchange 
receipts, but they view that such a rule-based intervention would not be appropriate under the current condition of the foreign exchange market in Indonesia.

\section{Financial Sector Issues}

11. Indonesian financial sector is resilient and well placed to weather the current global turmoil. Financial soundness indicators show that the banking system has performed favorably, with strong credit growth, well-capitalized, and liquid. Despite the strong credit growth, the loan quality continued to improve, with NPL falling to $4 \%$ in May 2008. The authorities' recent stress-test confirms that in general bank capital is strong enough to overcome the various simultaneous shocks, including interest rate increase, exchange rate depreciation, a fall in the government bond prices, and rising NPLs. Non bank financial institutions and capital markets continued to grow amidst pressures stemming from global market fallouts. Looking forward, our authorities remain vigilant, particularly over the rapid growth of consumer loans and will continue to monitor closely.

12. Our authorities have taken further steps to strengthen institutional aspects of the banking system aimed at building the resilience of the banking system in the face of global competition. BI continues to play a facilitating role in the merger process for the banking consolidation program, particularly for systematically important banks. Steps have also been taken by the central bank to accelerate development of financial markets and instruments in order to create a sound, robust financial sector. Moving ahead, the authorities are planning to gradually implement Basel II in 2008 with a differentiated pace across banks. On the bank governance, banks are required to be fully compliant with good corporate governance (GCG), including disclosure of their GCG in reports to the public. At the same time, the central bank requires banks to enhance transparency of their banking products towards the public.

\section{To strengthen coordination among agencies in a crisis management, our} authorities are planning to enhance legal aspects of financial crisis management. The draft of Financial Safety Net Act as a legal basis for bank resolution is being prepared by the authorities. The authorities are also preparing a financial crisis management protocol that outlines procedures and clarifies the responsibility of agencies in the event of financial crisis. In addition, coordination among financial agencies will be improved by strengthening the role of the Financial Stability Forum.

\section{Structural Reforms}

14. Reforms for improving investment climate remain the government's top priority. Following the implementation of the government's comprehensive June 2007 economic policy package, business perceptions of Indonesia's investment climate have shown some improvements, as reflected in the stronger growth of investment.[1] To further 
expedite private investment and spur economic growth, our authorities recently issued a new policy package on investment climate, acceleration of infrastructure development, empowerment of small medium enterprises, and financial sector development. Other key policies in the package include improvement of the management of the country's natural resources, environment, and agriculture sector, and reform of labor and transmigrations. The policy package also addresses energy supply, upgrading infrastructure, and speeding up the preparations toward ASEAN economic integration.

\section{Conclusion}

\section{The Indonesian economy has shown strong performance, with high growth} and sound macroeconomic stability, despite the current unfavorable global economic environment. While this remarkable performance has been attributed to sound macroeconomic policies and continued reforms over the past years, the authorities are determined that further broad based reforms are needed to secure the high quality and sustainable growth path over the medium term. In particular, our authorities underscore the need to be more vigilant and stand ready to adjust their economic policy mix to ensure that macroeconomic stability remain kept in check under the current challenging situations. Finally, the Indonesian authorities remain committed to transparency and consent to the publication of the staff reports, with necessary deletions of market sensitive information.

[1] The recent World Bank's business survey also suggests that business perceptions of investment climate in Indonesia show some improvement in recent years, with significant improvement in the business perception on policy predictability and macroeconomic stability. 